
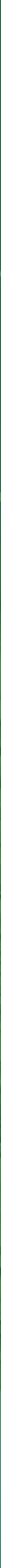

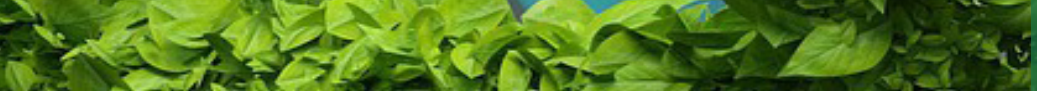

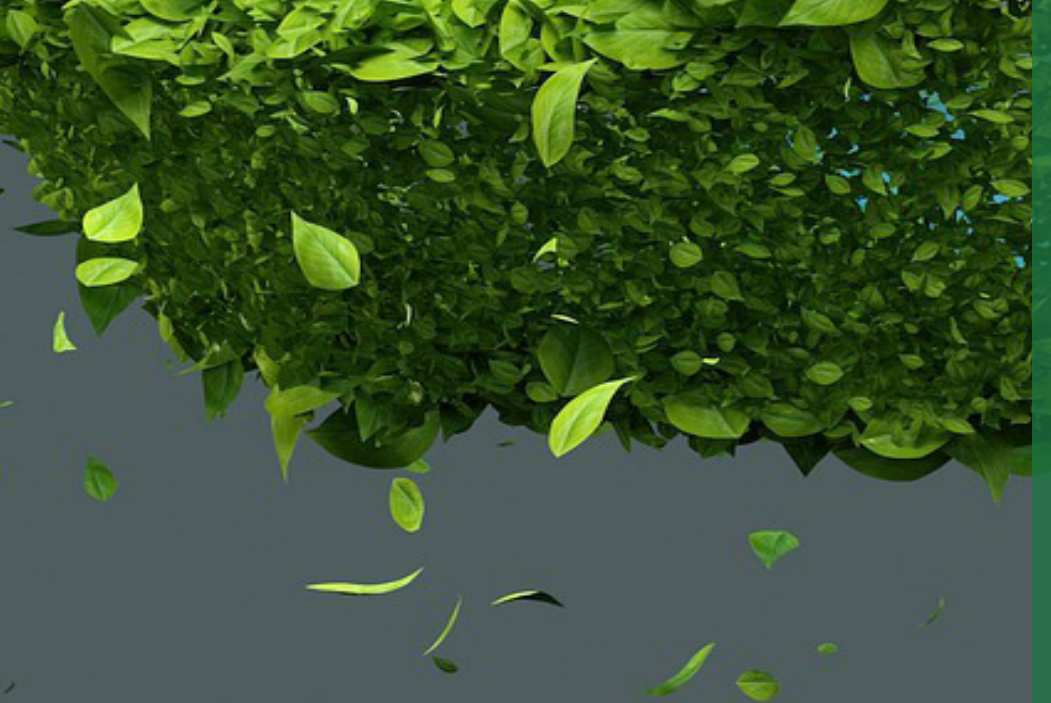

Rodrigo Duarte Faccin Gabriella Eldereti Machado Erimar Pereira da Rocha Organizadores

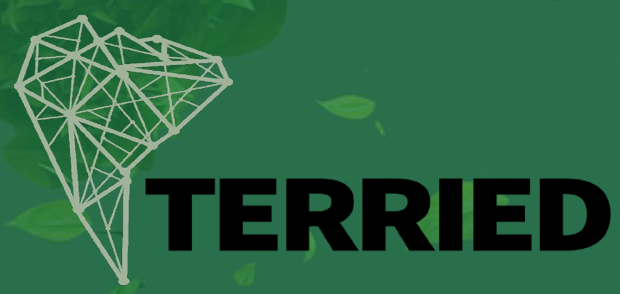


EDƯCAÇÃO AMBIENTAL

\section{EM DISCUSSÕES INTERDISCIPLINARES}

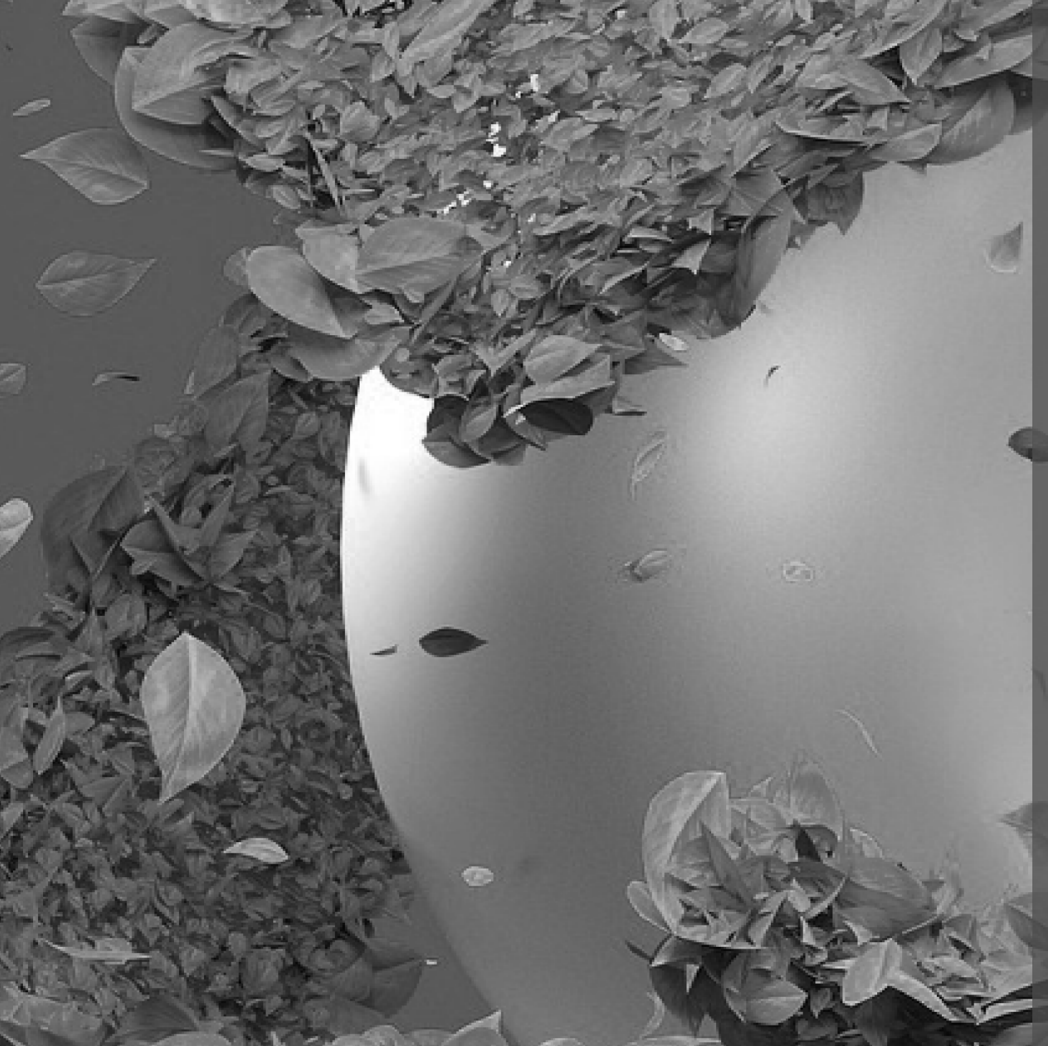

- $3504 x^{2}=0$
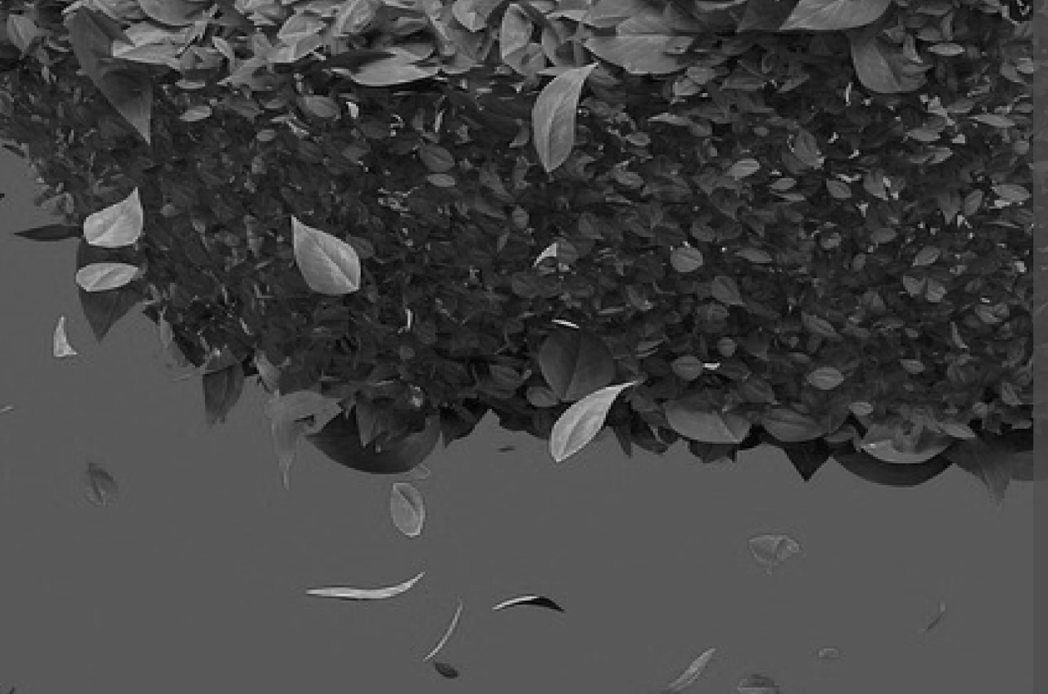

Rodrigo Duarte Faccin Gabriella Eldereti Machado Erimar Pereira da Rocha Organizadores

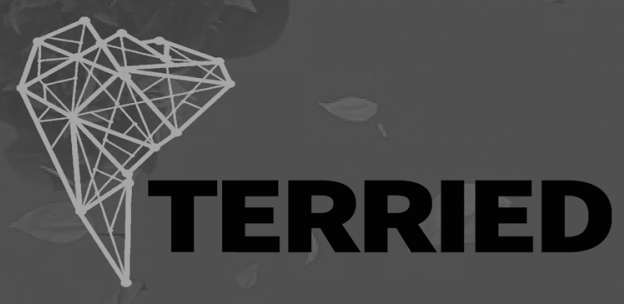


1. ${ }^{a}$ Edição - Copyrights do texto - Autores e Autoras

Direitos de Edição Reservados à Editora Terried

O conteúdo dos capítulos apresentados nesta obra são de inteira responsabilidade d@s autor@s, não representando necessariamente a opinião da Editora.

Permitimos a reprodução parcial ou total desta obra, considerado que seja citada a fonte e a autoria, além de respeitar a Licença Creative Commons indicada.

\section{Conselho Editorial}

Adilson Cristiano Habowski

Anísio Batista Pereira

Adilson Tadeu Basquerote Silva

Alexandre Carvalho de Andrade

Cristiano Cunha Costa

Celso Gabatz

Denise Santos Da Cruz

Emily Verônica Rosa da Silva Feijó

Fernanda Monteiro Barreto Camargo

Fredi dos Santos Bento

Fabiano Custódio de Oliveira

Guilherme Mendes Tomaz dos Santos

Leandro Antônio dos Santos

Lourenço Resende da Costa

Marcos Pereira dos Santos
Diagramação:

Gabriel Eldereti Machado

Revisão:

dos/as autores/as.

Capa:

Gabriel Eldereti Machado

imagem capa:

www.pixabay.com 


\section{Dados de Catalogação na Publicação (CIP)}

\section{EDUCAÇÃO AMBIENTAL EM DISCUSSÕES INTERDISCIPLINARES}

[livro eletrônico] / organização Rodrigo Duarte Faccin; Gabriella Eldereti Machado; Erimar Pereira da Rocha. -- Alegrete, RS : TerriED Editora, 2022.

$\mathrm{PDF}$

ISBN $978-65-995948-7-8$

1. Educação. 2. Ensino.

CDD -370

CDU-21-37/49

Índices para catálogo sistemático:

1. Educação 370.

\section{TERRIED}

www.terried.com

contato@terried.com

(55) 9656-1914 


\section{SUMÁRIO}

CAPÍTULO 1

LITERATURA DE CORDEL: ABORDAGENS PEDAGÓGICAS EM

SALA DE AULA.......................................................................................7

Cintia Regina Pavão Castelo Branco

Ueudison Alves Guimarães

doi: 10.48209/978-65-995948-7-2

CAPÍTULO 2

A INTER-RELAÇÃO ENTRE LITERATURA AFRICANA E BRASILEIRA： NA VISÃO DE MUNDO.....................................................25

Cintia Regina Pavão Castelo Branco

Ueudison Alves Guimarães

doi: 10.48209/978-65-995948-7-3

CAPÍTULO 3

EDUCAÇÃO: BREVE REFLEXÃO SOBRE O PROCESSO DE AVALIAÇÃO DA APRENDIZAGEM.........................................................35

Maria Betânia de Oliveira Marques

Ueudison Alves Guimarães

doi: 10.48209/978-65-995948-7-4

CAPÍTULO 4

CONSCIENTIZAÇÃO DOS RIBEIRINHOS SOBRE A IMPORTÂNCIA DA PRESERVAÇÃO AMBIENTAL DO RIO MANSO.

Leidiane Aparecida dos Santos

Ueudison Alves Guimarães

doi: 10.48209/978-65-995948-7-5 
CAPÍTULO 5

O LÚDICO COMO ELEMENTO MOTIVADOR NA EDUCAÇÃO DAS CRIANÇAS DO CAMPO EM ATALAIA - AL........................................65

Maria Betânia de Oliveira Marques

Ueudison Alves Guimarães

doi: 10.48209/978-65-995948-7-6

CAPÍTULO 6

EDUCAÇÃO DO CAMPO X EDUCAÇÃO AMBIENTAL: CAMINHOS QUE SE CRUZAM?

.97

Danilo Fernandes Lobato

Renata José de Melo

Olga Matias Teles Honorato

Simara Maria Tavares Nunes Simões

doi: 10.48209/978-65-995948-7-7

CAPÍTULO 7

A EDUCAÇÃO AMBIENTAL EM ESPAÇOS NÃO FORMAIS DA EDUCAÇÃO INFANTIL: PROPOSTAS DE METODOLOGIAS TRANSFORMADORAS.

Alex de Lima e Silva

Evandro José Branches Lopes Filho

Paulo Roberto Valdo Thomaz

Patricia Laurindo da Cunha Passos

Patrícia Vasconcelos Costa

Rose Cléia Maria Barros Mendes

doi: 10.48209/978-65-995948-7-1

SOBRE OS ORGANIZADORES. 
doi: 10.48209/978-65-995948-7-2

\section{GAPÍTULO 1}

S.

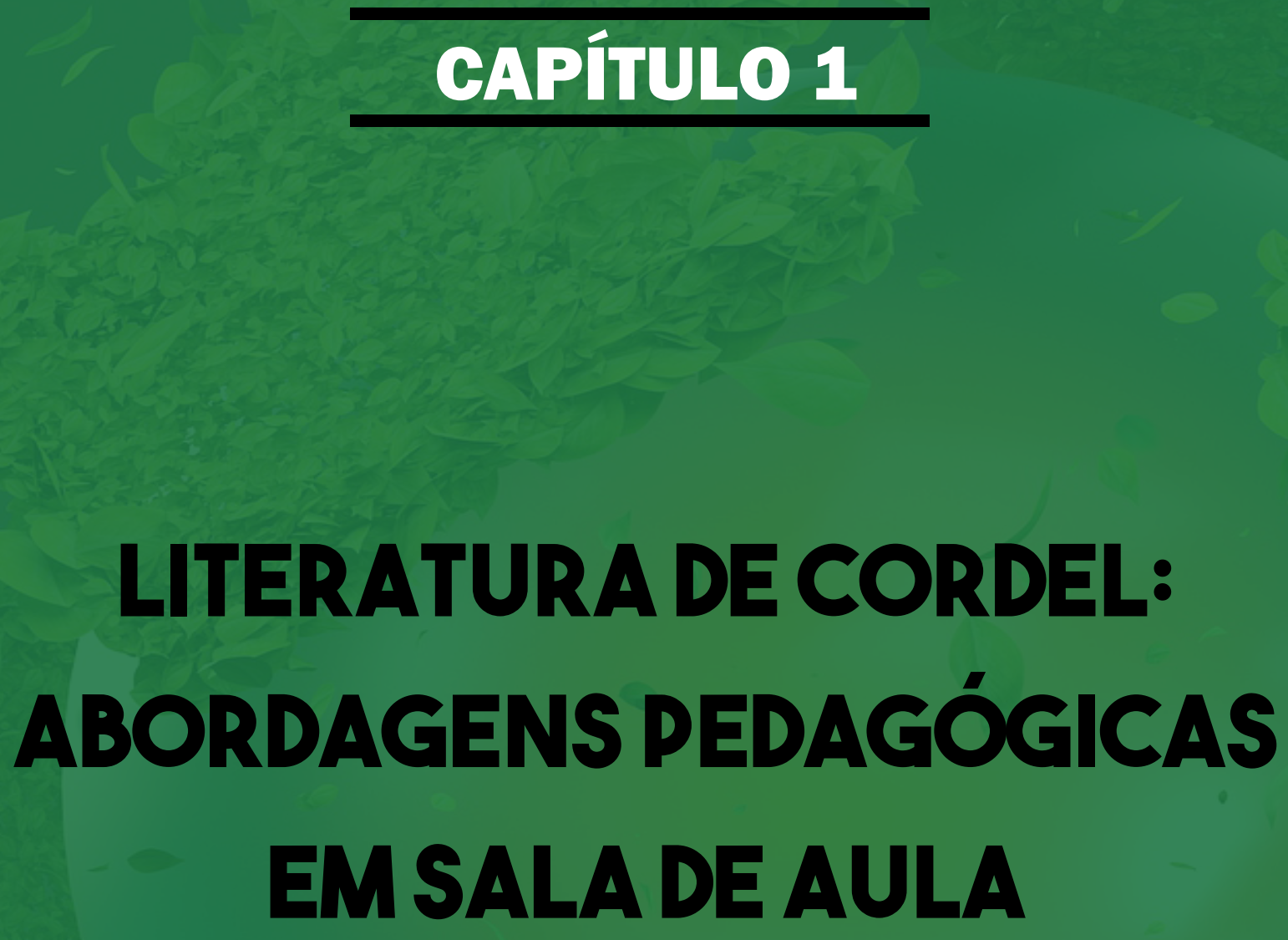

Cintia Regina Pavão Castelo Branco

Ueudison Alves Guimarães 
RESUMO: O presente estudo tem como tema O Ensino da Literatura de Cordel parte integrante da disciplina de Língua Portuguesa no Ensino Médio. Onde se objetivou mostrar a importância do ensino de cordel no desenvolvimento intelectual dos educandos. Dizer como o ensino de cordel pode contribuir na prática de leitura e conhecimento de todo um período retratado em folhetos, prosas, métricas, rimas e poesias. Demonstrar qual seria o principal diferencial do ensino desse momento da Literatura de Cordel como instrumento de uma abordagem pedagógica pautada em incentivar o discente a criar poemas e prosas em relação ao mundo atual, na realidade hoje vivenciada.

Palavras-chave: Literatura de Cordel. Abordagem Pedagógica. Língua Portuguesa.

ABSTRACT: The present study has as its theme The Teaching of Cordel Literature an integral part of the discipline of Portuguese Language in High School. Where the objective was to show the importance of teaching cordel in the intellectual development of students. To say how the teaching of cordel can contribute to the practice of reading and knowledge of an entire period portrayed in pamphlets, prose, metrics, rhymes and poetry. To demonstrate what would be the main differential of the teaching of this moment of Cordel Literature as an instrument of a pedagogical approach based on encouraging the student to create poems and prose in relation to the current world, in the reality experienced today.

Keywords: Cordel Literature. Pedagogical Approach. Portuguese language.

\section{INTRODUÇÃo}

Conforme Santos (2005), o Cordel chegou a América Latina através de colonizadores portugueses e espanhóis. O Cordel em Portugal era chamado de "Folhas Soltas", na Espanha era conhecido como "Pleitos Sueltos" e na França "Litérature de Colportage". Quando chegou ao Brasil ficou conhecido como Folheto de Feira ou Literatura Popular em versos.

Ainda conforme Santos (2005), os Cordéis eram baseados em narrativas europeias medievais que eram contadas em voz alta. Seus assuntos eram os mais variados possíveis relatando fatos políticos e sociais, eram lendas, histórias eruditas, romances, fatos históricos, viagens, guerras, confrontos entre o bem e o mal. Aos poucos o Cordel foi baseando-se na vivência nordestina no Brasil, criando dessa forma raízes características, 
percebe-se isso pela utilização de temas como secas e enchentes servindo como relatos das histórias.

O ensino da Literatura em sala de aula já é um desafio, e ainda mais quando se trata de um assunto como Cordel, muitas vezes sequer conhecido entre os alunos do ensino médio. É necessário nos ancorarmos em autores como Bakthin, Vygotsky, Chiappini, Rojo e vários outros para que se possa trabalhar literatura, pois muitos pensam apenas na arte esquecendo-se do contexto histórico que existe. É necessário despertar no aluno do ensino médio principalmente, a leitura e interpretação de texto de Cordel.

O interesse em abordar esse assunto surgiu como relevância para iniciar um trabalho de leitura especificamente em Cordel, pela dificuldade do professor em trabalhar esse contexto em forma de arte, e também em configurar um outro olhar para essa obra tão rica. Instigar o aluno a criar um senso crítico; sua observação da realidade quando se trata das variações linguísticas fortemente encontradas na região Nordeste. E justamente ancorados em Bakthin que mergulhamos no gênero do discurso.

Também é importante destacar que foi durante estágio que surgiu esse interesse, por perceber que os alunos não têm nenhum conhecimento significativo sobre Literatura de Cordel. Considerando-se importante inseri-la, através das diversas variáveis metodológicas, no ambiente escolar, como ponto de partida o entendimento de suas amplas diversidades de temáticas e estilos. E também por meio das reflexões sobre os gêneros do discurso elaborados por Bakthin.

Os Parâmetros Curriculares Nacionais (1998) sugerem ensino interdisciplinar e contextualizado, voltado para o ensino da cidadania, senso crítico e capacidade de interpretação, não só de textos, mas também de mundo. O mundo é precedido do processo da comunicação, é necessário registrar a história, interagir entre si, conviver em grupo e é na arte da leitura que toda uma trajetória de uma determinada época sai das páginas do livro e adentra as salas de aula. Só que a maneira simplista em que os PCN tratam a Literatura de Cordel quando a classificam apenas como um gênero oral, deixando de lado seus agentes discursivos, as vozes sociais que existem no texto, a composição e estilo. 
Cordel tem uma riqueza estilística inenarrável, mas possibilita um debate sobre a realidade social, política e econômica, que nos coloca em sintonia com a visão sócio interacionista de aprendizagem proposta pelo psicólogo russo Vygotsky, uma vez que ele concebe a educação formal, desenvolvida na escola, em termos de interação, a qual aponta o caráter como instrumento essencial de humanização.

A Literatura de Cordel pode ser definida como patrimônio da cultura nordestina, à medida que propicia o resgate histórico da cultura tradicional. Suas histórias mais antigas foram contadas de geração em geração. Cordel reflete as vivências, a imaginação, a fé, a devoção de um povo nordestino, e assim possibilita a investigação dos mais diversos processos culturais.

Por meio dos versos rimados, retrata valores nordestinos, e ao mesmo tempo, há um convite para refletir sobre a realidade social. Esse tipo de literatura carrega a herança cultural de diversos grupos e sociedades, e pode-se considerá-lo como prática sócio- discursiva.

Durante a apresentação desse trabalho, irá conceber a Literatura de Cordel como recurso didático que possibilita a inserção de ideias para atuação na sociedade, haja vista, esse tipo de literatura construir um conhecimento aliado à realidade.

Lendo esse tipo de Literatura, terá historicidade, e isso irá propiciar a análise desse gênero textual no conjunto das relações sociais, pois resulta da relação entre o ser humano e seu tempo. Prefere-se optar por trabalhar a Literatura de Cordel numa perspectiva de conhecimento histórico-social inserido na arte.

\section{FUNDAMENTAÇÃo TEÓRICA}

Segundo Bakthin (2000) seja qual for a esfera da atividade humana, ela estará sempre relacionada à utilização da língua e essa será efetuada sob a forma de enunciados, orais ou escritos, que irão refletir as condições específicas e as finalidades de cada uma dessas esferas. O todo do enunciado será a fusão de três elementos: conteúdo temático, estilo e construção composicional. 
E a partir desse momento Bakthin propõe o conceito de gêneros do discurso. "Qualquer enunciado consideravelmente é individual, mas a esfera de utilização da língua elabora seus tipos relativamente estáveis de enunciados, sendo que denominamos gênero do discurso”. (BAKTHIN, 2000, p. 279)

A variação da capacidade humana é muito grande os gêneros do discurso são de uma variedade maior ainda, onde se vê expressivamente uma heterogeneidade. Mas, o autor faz distinção e separa gêneros primários e os secundários.

Importa, nesse ponto, levar em consideração a diferença essencial existente entre o gênero do discurso primário (simples) e o gênero do discurso secundário (complexo). Os gêneros secundários do discurso - o romance, o teatro, o discurso científico, o discurso ideológico, etc. - aparecem em circunstâncias de uma comunicação cultural mais complexa e relativamente mais evoluída principalmente escrita: artística, científica, sócio-política. Durante o processo de sua formação, os gêneros secundários, os gêneros secundários absorvem e transmutam os gêneros primários (simples) de todas as espécies, que se constituíram em circunstâncias de uma comunicação verbal. (BAKTHIN, 2000 apud ALVES, 2008, p. 105).

E de acordo com essa classificação, pode-se considerar a Literatura de Cordel como um gênero secundário e plurivocal, uma vez que se trata de uma manifestação artística dentro da cultura popular.

Vale lembrar que, quando os gêneros primários se tornam componentes dos gêneros secundários, passam por uma transformação e adquirem uma característica particular: rompe-se sua relação imediata com a realidade existente e com a realidade dos enunciados alheios. Além disso, não se pode deixar de observar que alguns gêneros possuem maior facilidade de refletir a individualidade da língua, enquanto outros, por possuírem formato padronizado, não permitem isso. No primeiro caso, podemos citar como exemplo os gêneros literários. (BAKHTIN, 2000).

Bakthin (2000) dividiu os gêneros em dois grupos: primário e secundário. Pela ordem, os gêneros primários, também são considerados simples, são aqueles que resultam das situações de comunicação verbal, não são elaborados e possuem caráter espontâneo. São gêneros primários devido sua informalidade, é o que chamamos de uso imediato da 
linguagem, como uma conversa entre amigos, reunião familiar.

Para os gêneros secundários, os complexos, tem-se uma configuração imediata, uma instrumentalização, constrói um enunciado mais desenvolvido, como o romance, as pesquisas científicas, publicidade etc.

Brait (2008 apud MARTINS; SPIRLANDELLI; MAGALHÃES, p. 13), explica que:

Mesmo considerando a existência de estilos de aprendizagem, dialetos sociais etc. como componentes de um estilo, ou caracterizadores de estilo, a busca é no sentido de saber sob que ângulo dialógico eles se confrontam numa obra, num texto, num enunciado. E, segundo Bakthin o ângulo dialógico não pode ser estabelecido por meio de critérios genuinamente linguísticos, porque as relações dialógicas pertencem ao campo do discurso.

E no caso de Literatura de Cordel, é claro quanto à sua classificação nos gêneros secundários, já que tem uma estrutura complexa e bem elaborada. Cordel tem um estilo próprio de língua. A escola e o professor só devem tomar cuidados quanto ao tipo de comunicação que o Cordel trás, que não apenas gramatical ou literária, mas acima de tudo o contexto de sua riqueza quanto às discussões sociais, históricas, políticos e econômicos do nosso país.

A Literatura de Cordel tem seu papel social no ambiente nordestino e o seu papel atua sobre uma sociedade analfabeta, e quando lida pelos alfabetizados, ajuda a transmitir conhecimentos da massa rural. Foi comprovado que pessoas aprenderam a ler e escrever por meio dos folhetos. (MEYER, 1980 apud MARTINS; SPIRLANDELLI; MAGALHÃES, p. 33).

A população analfabeta se deliciava com as narrativas tradicionais, os romances herdados da tradição histórica ou novelística que eram transferidos da prosa para a poesia.

A literatura de cordel se tornou um instrumento de comunicação que divulgava acontecimentos para a população, numa época em que os meios de comunicação modernos eram de difícil acesso. Assim: 
Tornava-se o folheto o elemento mais expressivo para que os acontecimentos chegassem aos conhecimentos de todos, lidos nos mercados, nas feiras, nos serões familiares, em parte como ainda hoje sucede (DIÉGUES JR, 1977 apud MARTINS; SPIRLANDELLI; MAGALHÃES, p. 33).

Desta forma, como a Literatura de Cordel é composta por uma narrativa, veicula os valores sociais do povo nordestino, dando voz aos excluídos, aos retirantes, aos sertanejos.

E com a proposta de Bakthin (2000), que afirma que descrever um gênero é estilo, esse trabalho sobre Cordel revela a criatividade linguística, sobre a oralidade, sem deixar de considerar a complexidade desse gênero e o valor social que ele representa.

Magalhães (2005 apud ALVES, 2008, p. 106) corrobora ao destacar que a literatura vem sendo usada como pretexto para o ensino da gramática, e, por isso, sua relação com a vida tem se perdido, fato que tem levado ao abandono da reflexão sobre a realidade em detrimento da expressão da forma linguística.

Segundo Chiappini (2005 apud ALVES, 2008, p. 107), para que os textos sejam realmente compreendidos é necessária uma visão interdisciplinar, a qual irá exigir muito mais que a decodificação de sinais. A leitura é vista como parte do mundo e, por isso, requer a mobilização de diversos conteúdos que irão se constituir na interação texto leitor. Nessa relação, serão de fundamental importância os objetivos do leitor, porque são eles que vão determinar a busca pelo aprofundamento em determinados conteúdos e métodos.

O trabalho revelou-se de grande importância devido ao trabalho dos docentes em sala de aula em relação à Língua Portuguesa e a ênfase dada à Literatura de Cordel, como uma maneira de fazer com que o aluno entenda e perceba da importância dessa fase histórica no estudo da disciplina de português. Muitos alunos eu antes desconheciam Cordel, ficaram impressionados com tamanha riqueza de assuntos da época, e a curiosidade fez com eu adentrasse nesse mundo de histórias tão dramáticas e reais.

Os Parâmetros Curriculares Nacionais (1998) sugerem ensino interdisciplinar e contextualizado, voltado para o ensino da cidadania, senso crítico e capacidade de interpretação, não só de textos, mas também de mundo. O mundo é precedido do processo 
da comunicação, é necessário registrar a história, interagir entre si, conviver em grupo e é na arte da leitura que toda uma trajetória de uma determinada época sai das páginas do livro e adentra as salas de aula. Só que a maneira simplista em que os PCN tratam a Literatura de Cordel quando a classificam apenas como um gênero oral, deixando de lado seus agentes discursivos, as vozes sociais que existem no texto, a composição e estilo.

Cordel é um tipo de poema popular oral e impresso em folhetos, que são geralmente expostos para venda pendurados em cordas ou cordéis - daí seu nome. O nome Cordel é originário de Portugal, o qual tinha a tradição de pendurar folhetos em barbantes. Tem um linguajar despreocupado, regionalizado e informal.

A manifestação do autor é o intuito e objetivo do Cordel, acerca de algo de dentro da sociedade. Precisam ser convincentes e usam de um poder de persuasão a fim de que o leitor acate sua ideia proposta.

A Literatura de Cordel é representada e preserva sua sonoridade e sua gestualidade. O Cordel segundo Zumthor é "a palavra gesticulada dos poetas, que emerge dos folhetos, evocando memória e tradição em suas métricas e rimas por meio de narrativas as mais diversas".

É como qualquer outra forma artística uma manifestação cultural, que por meio das escritas são transmitidas as cantigas, os poemas, e as histórias do povo, pelo próprio povo. A literatura de cordel é um instrumento que desperta o interesse pela leitura, a musicalidade das rimas encanta a todos que escutam ou leem cordel.

As primeiras manifestações ocorreram no ocidente por volta do século XII, onde os Peregrinos encontravam-se no Sul da França, em direção à Palestina; no norte da Itália para chegar a Roma; e ainda na Galícia, no Santuário de Santiago.

Nesses encontros eram transmitidas as histórias e compostos os primeiros versos, tudo de forma bastante primitiva. Mas, o que nos interessa, é que foi dessa forma que surgiram os primeiros núcleos de cultura regional os quais espalharam-se pela Europa, e depois pela América. 
Devido ao atraso da chegada da imprensa pelo Brasil e seu acesso pelo público, as produções literárias de populares, tiveram seu apogeu apenas no século XX.

Nossa literatura de cordel é caracterizada, principalmente pela poesia popular, pois a prosa apareceu muito mais na forma oral, que passou de geração a geração. É um tipo de manifestação mais cultural que intelectual, por isso em determinadas regiões foi mais valorizada e delineada, ou seja, na região nordeste e sul.

A concepção era de que a literatura poesia popular era para as classes sociais mais baixas e a literatura para as classes mais favorecidas. Porém, a partir da década de 1960 essa forma de pensar começou a mudar, porque a imigração dos nordestinos para as demais regiões brasileiras despertou o interesse dos intelectuais pelos folhetos de cordel.

E aos poucos foi surgindo os cordelistas, ou seja, uma nova geração de poesia. Esses poetas tiveram acesso a um novo mundo e passaram a escrever sobre as mais diversas áreas que envolvem a sociedade, e não somente aos assuntos relativos ao local que antes habitavam.

Os cordéis tratavam sobre: filosofia, política, economia e assuntos que interessavam sobre o mais novo público-alvo: os estudantes, pesquisadores e os intelectuais.

Houve uma grande reviravolta com o então preconceito, pela mescla do conhecimento. E o país está marcado pela miscigenação de etnias.

Os trabalhos dos cordelistas não são apenas os folhetos pendurados, são notícias que foram divulgadas com a finalidade de alcançar a todos na época. Muitas pessoas claro que já ouviram falar dos folhetos de cordel, a poesia é um patrimônio cultural da sociedade brasileira.

E este trabalho também levanta também um assunto sugerido em sala de aula, sobre que a poesia está sempre se adaptando, e, por isso até hoje sobrevive em nossa era contemporânea. Mesmo havendo tanta difusão de tecnologias de ponta e eixos mundiais, ainda assim pode-se perpetuar a literatura no meio desses jovens proporcionando-lhes o conhecimento de vossas culturas e andanças enquanto gerações. 
Alguns estudiosos acreditam que a literatura de cordel chegou ao Brasil na primeira metade do século XVI.

Penso que o hábito de decorar histórias, dos cantos de trabalho, as cantigas de embalar e toda a sorte de narrativas orais trazidas pelos colonizadores vão sedimentando, na cultura brasileira, o costume de cantar e contar histórias, de guardar os acontecimentos da vida cotidiana. Assim, pouco a pouco, foi se desenvolvendo junto ao povo brasileiro, mais especificamente na região Nordeste, onde se deu o início da colonização, uma poesia oral com características muito peculiares. (BARROSO, 2006, p.22)

Uma das primeiras formas de cordel conhecidas foi a cantoria de viola do grupo de poetas da Serra do Teixeira, no Estado da Paraíba, no final do século XVIII. Eles criaram as sextilhas sete silábicas. E o poeta Agostinho Nunes da Costa foi o primeiro cantador desse grupo.

O auge dessa literatura de cordel ocorreu no Brasil por volta de 1930. E segundo Galvão (2001), nessa época ocorreu a montagem das "redes de produção e distribuição dos folhetos, com centenas de títulos publicados e o editor deixou de ser exclusivamente poeta".

O editor em destaque nessa época foi João Martins Athayde.

Nessa época o cordel era fonte de lazer e informação, entre 1930 e 1940, onde as pessoas se socializavam.

Diegues Jr fala dessa importância:

Instrumento de comunicação, alargou-se depois da divulgação dos fatos acontecidos, coisas de que a população não podia ter conhecimento senão de por essa forma. Rádio não existia; jornal era raro. Quando este chegava, levado dos grandes centros - Recife ou Fortaleza, por exemplo - com o atraso normal dos meios de transporte de então já o folheto se antecipava na divulgação do fato.

Tornava-se o folheto o elemento mais expressivo para que os acontecimentos chegassem ao conhecimento de todos, lidos nos mercados, nas feiras, nos serões familiares.

A partir da década de 1960 veio uma crise que o cordel passou, o público mais letrado passou a se interessar por ele. Galvão (2001) registra que tanto por turistas quanto 
por universitários, brasileiros e estrangeiros, o cordel passou a ser fonte de lazer e estudo. Os folhetos antes vendidos em feiras pelo próprio cordelista, passaram a ter maior distribuição pelas editoras, com grande espaço em livrarias e lojas de artesanato.

Podendo ser cantada ou escrita, conhecida tão somente como cantorias, repentes - poemas improvisados. É uma obra oral, porém não deixa de lado a metrificação e as rimas.

Existem várias modalidades tais como: A Sextilha constituída de seis versos de sete sílabas. Tinha também a Sete Linhas ou Sete Pés, A Décima e o Martelo Agalopado.

Ilustrando capas dos folhetos, sendo o chamariz para o leitor, sempre destacando os temas. A Xilogravura é uma técnica artesanal no qual as matrizes de impressão são esculpidas em madeira. A etimologia da palavra vem de origem do grego xilon(madeira) e grafo (escrever). A arte de escrever na madeira.

De acordo com Bragatto (1995) o professor deve se posicionar em favor do texto literário na conquista da formação do leitor e conseguir criar um ambiente favorável entre o aluno e sua relação de afetividade com o livro. Par isso, o primeiro passo é que o professor goste de ler. Uma excelente sugestão é promover uma sala de leitura com narrativas curtas, não muito densa e nem muito complexas.

Os Parâmetros Curriculares Nacionais apontam para a leitura colaborativa em que o professor lê o texto e durante a leitura investiga vestígios linguísticos presentes no texto.

Sobre esse tipo de leitura os PCN explicam:

A possibilidade de interrogar o texto, a diferenciação entre realidade e ficção, a identificação de elementos discriminatórios e recursos persuasivos, a interpretação de sentido figurado, a inferência sobre a intencionalidade do autor, são alguns dos aspectos dos conteúdos relacionados à compreensão de textos, para os quais a leitura colaborativa tem muito a contribuir. A compreensão crítica depende em grande medida desses procedimentos. (PCN,1998, p,45) 
Construir uma compreensão crítica é necessário estratégia de leitura com regularidade. Os PCNs informam que tais textos se constituem de forma própria e que predomina a criatividade e a imaginação intencional.

Em particular o cordel é uma prática de linguagem oral, a região Nordeste favorece uma vasta imensidão de temas para serem usadas em sala de aula.

A leitura de cordel em voz alta além de estimular a leitura e a escrita aproxima a poesia popular com os acontecimentos reais do cotidiano do aluno. Essa mesma leitura oral possibilita a percepção da beleza da cultura popular.

A preparação dos textos a serem utilizados em sala de aula é primordial, é preciso treinar a entonação, as rimas e a musicalidade. A informação sobre a história daquela leitura e sua estrutura poética também se faz importante saber. Discutir regionalismos, metáforas, fatos históricos referentes à narrativa, são aspectos relevantes para serem usados em sala de aula.

$\mathrm{Na}$ abordagem do regionalismo é importante frisar os diálogos dos sertanejos, suas crenças e seus dilemas são frutos do seu cotidiano e que a fala coloquial não está errada, apenas situada no ambiente no qual o cordel foi criado.

Cordel tem uma riqueza estilística inenarrável, mas possibilita um debate sobre a realidade social, política e econômica, que nos coloca em sintonia com a visão sócio interacionista de aprendizagem proposta pelo psicólogo russo Vygotsky, uma vez que ele concebe a educação formal, desenvolvida na escola, em termos de interação, a qual aponta o caráter como instrumento essencial de humanização.

Durante a apresentação desse trabalho, iremos conceber a Literatura de Cordel como recurso didático que possibilita a inserção de ideias para atuação na sociedade, haja vista, esse tipo de literatura construir um conhecimento aliado à realidade.

Cordel é um tipo de Literatura que tem historicidade, e a grande importância dessa pesquisa é mostrar ao aluno os tipos de gêneros textuais existentes, e diferenciar o que 
pode ser trabalhado hoje, e como esse tipo de gênero atraia as pessoas da época. Há por trás de tudo isso, o conhecimento da história e a arte explicitada nos versos, prosas penduradas nos folhetos.

\section{MATERIAIS E MÉTODOS}

A presente pesquisa tem por finalidade mostrar a importância do trabalho da Literatura, mas especificamente a Literatura de Cordel como abordagem pedagógica nas escolas.

A metodologia utilizada na pesquisa apoia-se na pesquisa bibliográfica, qualitativa analítica-descritiva, e ao longo de todo o trabalho, isto é, em artigos com bases em autores que definem a Literatura de Cordel, sua evolução e seu contexto histórico. A escola na qual a pesquisa foi realizada denomina-se: Unidade de Ensino Cidade de São Luís que fica localizada na Avenida IV, no Bairro da Cohab Anil IV, na Cidade de São Luís/Ma. Em seguida, foi realizado estudo de campo através dos estágios, embasado na pesquisa qualitativa, cuja característica foi primeiramente a observação e posteriormente a prática de estágio com os alunos em sala de aula, onde os mesmos apresentaram a confecção dos folhetos de cordel e repaginaram os personagens de acordo com a época atual, traçando um retrato fiel dos dias atuais.

Os dados coletados iniciaram-se através de um cronograma estipulado em dias e horários de acordo com o horário de aula do professor, no período de 15 de fevereiro a 15 de março de 2017.

Andrade (2003, pág. 121 apud Maso, 2010, pág. 15) ensina que a pesquisa é o conjunto de procedimentos sistemáticos, baseados, no raciocínio lógico, que tem por objetivo encontrar soluções para problemas propostos, mediante a utilização de métodos científicos.

Considerando que a pesquisa é de muita relevância para a formação de leitores críticos com um olhar diferenciado quanto ao estudo da literatura e seu contexto, quanto à realidade cultural, sócio econômica e política de outrora e dos nossos dias atuais. 


\section{RESULTADOS E DISCUSSÕES}

O maior objetivo do trabalho foi compreender os desafios dos professores em abordar Cordel em sala de aula para alunos de ensino médio. Sabendo que é a melhor oportunidade do aluno ter contato com uma experiência cultural que emana uma riqueza profunda e expressiva, tendo em vista as diversas e várias linguagens, que vai da escrita, passa pela oral, visual e musical.

Segundo Bakthin (2000) seja qual for a esfera da atividade humana, ela estará sempre relacionada à utilização da língua e essa será efetuada sob a forma de enunciados, orais ou escritos, que irão refletir as condições específicas e as finalidades de cada uma dessas esferas. O todo do enunciado será a fusão de três elementos: conteúdo temático, estilo e construção composicional.

De acordo ainda com o autor acima citado, cordel é considerado gênero secundário e plurivocal, uma vez que se trata de uma manifestação artística dentro da cultura popular. E é nessa vertente que o professor deve fazer de sua ação pedagógica uma maneira de permear no mundo dos discursos de gêneros.

Bakthin (2000) dividiu os gêneros em dois grupos: primário e secundário. Pela ordem, os gêneros primários, também são considerados simples, são aqueles que resultam das situações de comunicação verbal, não são elaborados e possuem caráter espontâneo. São gêneros primários devido sua informalidade, é o que chamamos de uso imediato da linguagem, como uma conversa entre amigos, reunião familiar.

Para os gêneros secundários, os complexos, tem-se uma configuração imediata, uma instrumentalização, constrói um enunciado mais desenvolvido, como o romance, as pesquisas científicas, publicidade etc.

Cordel tem seu estilo genuíno de ser, tem sua riqueza, única e individual, e pode ser trabalhado em conjunto com a gramática e literatura. Seria muito importante que o professor atuante da Língua Portuguesa tivesse um olhar diferenciado para essa aborda- 
gem pedagógica com os alunos do ponto de vista de evidenciar o contexto social, histórico, político e econômico que cordel traz.

Muitos discentes em sua maioria desconheciam cordel, e no estágio durante a aplicação desse tipo de leitura, foi possível fazê-los ler, interpretar e atuar como atores de uma época tão importante em nossa história. Os folhetos foram os instrumentos que mais foram apreciados, e foram elaborados repentes, prosas e poesias voltados para a realidade atual.

Desta forma entende-se que a abordagem pedagógica de forma sistemática em sala de aula, é o caminho mais pertinente visando preparar o alunado para interpretar leituras e produção textual.

Os desafios são inúmeros atravessando um oceano de reflexões quanto às melhores práticas em sala de aula.

E assim também esse aluno conhece, respeita e valoriza a questão da multiculturalidade que é própria do nosso país, o imaginário, o folclore tudo isto bem presente na literatura e produção de cordel.

A aprendizagem é um processo pelo qual o aluno se apropria das experiências do seu cotidiano. O professor, no entanto, deve estar apto a na hora de ensinar, e se responsabilizar quanto a sua melhor atuação em sala de aula.

Contudo, o que se percebe é a distância do professor e aluno quanto a atividade da leitura, haja vista, o professor precisar ser um leitor assíduo. Muito importante também considerar que muitos alunos chegam ao ensino médio sem se apoderarem da escrita e leitura.

A escola é um espaço privilegiado para a elucidação da leitura, por isso que essa prática deve ser embrenhada desde tenra idade.

Assim, para a escola em geral e principalmente ao ensino médio, o professor deve injetar a Literatura de Cordel, pois o aluno irá vivenciar não só uma época, mas a liberdade linguística que só a literatura de cordel promove. 
É muito importante que os professores não se prendam somente aos livros didáticos, pois tudo repetitivo demais, pois vira mesmice, desânimo e cansaço.

Percebeu-se que quando se reinventa a leitura, tornando-a mais prazerosa, o aluno passa a interagir de maneira mais efetiva com os colegas.

Sobre a utilização da literatura como ferramenta de ensino os PCN afirmam que:

É importante que o trabalho com o texto literário esteja incorporado às práticas cotidianas da sala de aula, visto tratar-se de uma forma específica de conhecimento. Essa variável de constituição da experiência humana possui propriedades compositivas que devem ser mostradas, discutidas e consideradas quando se trata de ler as diferentes manifestações colocadas sob a rubrica geral de texto literário $(1997$, p. 29

\section{CONCLUSÃo}

Conhecer cordel foi imprescindível na construção desse trabalho que teve como objetivo a abordagem pedagógica em sala de aula. Apresentando assim ao docente uma nova maneira, um novo método de se abordar gramática, linguagem, variações linguísticas, e tornar o estudo dessas vertentes até bem mais prazerosa e dinâmica.

O referente trabalho une literatura a outras "veias" da Língua Portuguesa, proporcionando assim uma reflexão sobre a importância de se trabalhar outras ferramentas de ensino.

O professor é autor de sua obra, e buscar algo novo sempre e que possibilite uma aprendizagem diferente, contribui não só para o professor, mas, sobretudo para o aluno que porventura tenha dificuldade em relação à aprendizagem.

\section{REFERÊNCIAS}

ARRAES, Guel. O Auto da Compadecida. São Paulo: Globo Filmes, 2000

ALVES, Roberta Monteiro. Literatura de Cordel: por que e para que trabalhar em sala de aula. In: Revista Fórum Identidades, Sergipe, ano 2, v. 4, p. 103-109, 2008. Disponível em: https://seer.ufs.br/index.php/forumidentidades/article/download/1815/1601. Acesso em: 20 de abril de 2018. 
BAKHTIN, Mikhail. Estética da criação verbal. São Paulo: Martins Fontes, 2000.

BARROS, Josias Silvano de. Perspectivas pedagógicas com o cordel na cultura de multimeios. (PPGFP/UEPB). Disponível em: http://editorarealize.com.br/revistas/cintedi/trabalhos/Modalidade_1datahora_03_11_2014_23_25_39_idinscrito_3859_cd057acce287b0989abdc36269735084.pdf. Acesso em: 18 de abril de 2018.

BARROSO, Maria Helenice. Os cordelistas no D.F.: dedilhando a viola, contando a história. Dissertação de Mestrado pela Universidade de Brasília - UnB, 2006.

BRAGATO FILHO, Paulo. Pela leitura literária na Escola de $1^{\mathbf{0}}$ grau. São Paulo: Ática, 1995. pp. 85-92.

BRASIL. Parâmetros Curriculares Nacionais: Ensino Médio. Brasília, DF: MEC/ SEMTEC, 2002

CARDOSO, Vera Lucia Oliveira. Literatura de Cordel na Sala de Aula: Expressividade e cultura popular em versos. Instituto Federal de Educação, Ciência e Tecnologia - IFPB. Disponível em: http://2015.selimel.com.br/wp-content/uploads/2016/03/ Vera-Lucia-gt-13.pdf. Acesso em: 20 de abril de 2018.

COUTINHO, Afrânio. Introdução à literatura no Brasil. 17. ed. Rio de Janeiro: Bertrand Brasil, 2001.

DÍEGUES JÚNIOR, Manuel. Literatura de Cordel. Cadernos de Folclore. 2.ed. Rio de Janeiro: v.2, 1977

GALVÃO, Ana Maria de Oliveira. Cordel: leitores e ouvintes. Belo Horizonte: Autêntica, 2001.

MARTINS, Cristiane Roberta. SPIRLANDELLI, Ricardo Rejani. MAGALHÃES, Samuel Pires. Literatura de Cordel em Sala de Aula: Um estudo do gênero. Instituição: Uni-FACEF Centro Universitário de Franca. Franca, 10 de outubro de 2008. Disponível em: http://periodicos.unifacef.com.br/index.php/rel/article/view/378/363. Acesso em: 19 de abril de 2018.

ROJO, Rosane. O texto como unidade de ensino e o gênero como objeto de ensino da Língua Portuguesa. In: TRAVAGLIA, Luiz Carlos. Encontro na linguagem: estudos lingüísticos e literários. Uberlândia: EDUFU, 2006. 
SILVA, Silvio Profirio da. et al. Literatura de Cordel: Linguagem, Comunicação, Cultura, Memória e Interdisciplinaridade. Universidade Federal da Grande Dourados. Raído, Dourados, MS, v. 4, n. 7, jan./jun. 2010. Disponível em: http://ojs.ufgd.edu. br/index.php/Raido/article/view/603/539. Acessível em: 20 de abril de 2018.

VYGOTSKY, Lev S. A formação social da mente. São Paulo: Martins Fontes, 2007.

ZUMTHOR, Paul. Performance, recepção, leitura. Trad. de Jerusa Pires cap Ferreira et al. São Paulo: Educ, 2000. 
doi: 10.48209/978-65-995948-7-3

\section{GAPÍTULO 2}

\section{AINTER-RELAÇĀO} ENTRE LITERATURA

\section{AFRICANA E BRASILEIRA:}

NA VISĀO DE MUNDO

Cintia Regina Pavão Castelo Branco

Ueudison Alves Guimarães 
RESUMO: Este trabalho científico foi desenvolvido como atividade na disciplina de Seminário de Prática VII do curso de Letras da Uniasselvi, e tem como principal objetivo compreender a inter-relação entre as literaturas africana e brasileira articuladas na visão de mundo. $\mathrm{O}$ trabalho foi realizado em grupo, onde foram divididas as atividades e a pesquisa de artigos científicos, bem como a leitura dos mesmos e consequentemente a escolha dos mais relevantes ao tema. Os encontros se deram semanalmente, sempre após as aulas. Nas ocasiões foi discutido o tema e escolhido o título para ser desenvolvido. As coletas de informações ocorreram no período de 03 de março de 2018 a 12 de maio de 2018, nas bases de dados SCIELO, onde foram selecionados periódicos em português com produções a partir de 2005. Tendo em vista que seria necessário discutir “A Inter-relação entre Literatura Africana e Brasileira: na visão de Mundo.

Palavras-chave: Literatura, Cordel, Xilogravura, Poesia e Cultura.

ABSTRACT: This scientific work was developed as an activity in the discipline of Practice Seminar VII of the Letters course at Uniasselvi, and its main objective is to understand the interrelation between African and Brazilian literature articulated in the world view. The work was carried out in a group, where the activities and research of scientific articles were divided, as well as the reading of them and consequently the choice of the most relevant to the theme. The meetings took place weekly, always after classes. On occasions, the topic was discussed and the title to be developed was chosen. Data collection took place from March 3, 2018 to May 12, 2018 , in the SCIELO databases, where journals in Portuguese with productions from 2005 were selected. Relation between African and Brazilian Literature: in the world view.

Keywords: Literature, Cordel, Woodcut, Poetry and Culture.

\section{INTRODUÇÃo}

A literatura africana é preconizada pela Lei $n^{\circ} 10.639 / 03$, que é um caminho onde se conhece a História da África e dos Africanos na formação do Brasil. A partir dessa Lei que essa Literatura foi inserida nos currículos escolares, enfatizando a luta dos negros no Brasil, o estudo da História Africana e dos Africanos, e a presença do negro na formação da sociedade nacional. O negro contribuiu deveras nas áreas social, econômica e política do Brasil, e com ele veio "arrastando" a literatura negra.

As Literaturas de Língua Portuguesa do Brasil e dos países africanos são distintas, porém se aproximaram por problemas em comum. Houve tempos de guerras onde o caos 
foi instalado, e a tão sonhada construção da paz se distanciava cada vez mais. É a partir de nosso olhar que iremos abordar a inter-relação das duas literaturas, onde o flagelo ancorou e fez-se presente.

Contudo, um aspecto em comum muito importante é referente ao multiculturalismo, as atividades artísticas que apareceram trazendo em si todo um acervo literário da trajetória nessas nações. Nas palavras do autor, "é uma qualidade particular da experiência social e das relações sociais, historicamente diferente de outras qualidades particulares, que dá o senso de uma geração ou de um período" (WILLIAMS,1979 apud SOARES; 2011, p. 2).

Sabe-se que o ofício do professor de Língua Portuguesa dá acesso tanto aos alunos quanto aos livros literários, proporcionando um espaço de construção e troca de conhecimento, que vai além dos muros da escola. Estabelecendo um percurso que o possibilitar compreender e formar uma memória literária, possibilitando a construção de seus próprios pensamentos, textos e diálogos com o mundo em que vive.

Tendo em vista este pensamento, este trabalho tem como objetivo compreender inter-relação entre as literaturas africana e brasileira articuladas na visão de mundo. Partindo do pressuposto que este estudo proporcionará reflexões relacionadas à sua formação acadêmica, a fim de relacionar a pesquisa vigente com as disciplinas já estudadas ao longo do curso de Letras durante os semestres anteriores. Abordando artigos que trazem reflexões sobre os ecos e reflexos africanos na literatura brasileira.

\section{FORMAÇÃO DA IDENTIDADE NACIONAL}

$\mathrm{Na}$ tentativa de uma aproximação na busca pela paz e pela reconstrução social, os movimentos sociais iniciaram a construção de um estado autônomo e de direito. No desejo de mobilizar outro estilo de vida possível, os letrados com formação em Portugal, são chamados pelo lugar de outrora tão cheio de misérias e sofrimentos. A escrita era a única força que poderiam usar para fins de registros literários. 
A partir de 1950 e ao longo das guerras pela independência, é que se pode falar, pois, da formação de algumas das literaturas dos países africanos de língua portuguesa. Registros literários anteriores já tinham sido publicados, mas ainda não se reconhecia o que o crítico literário Antônio Candido chama de "sistema literário" e que configura o início de uma literatura vigorosa:

Entendo aqui por sistema e articulação dos elementos que constituem a atividade literária regular: autores formando um conjunto virtual, e veículos que permitam o seu relacionamento definindo uma "vida literária": públicos, restritos ou amplos, capazes de ler ou ouvir as obras, permitindo com isso que elas circulem e atuem ; tradição que é o reconhecimento de obras e autores precedentes, funcionando como exemplo ou justificativa daquilo que ser quer fazer, mesmo que seja para rejeitar"(CANDIDO, 1998, p. 6 apud AGAZZI 2011).

O fortalecimento das literaturas surgiu pelas problemáticas em comum que tinham. E os escritores povoavam o imaginário do povo, que as lia. Assim, se constitui uma maneira de escrever e fortalecer as identidades nacionais.

\section{UM OLHAR SOBRE AS LITERATURAS: INTERTEXTUALIDADE}

As Literaturas Africanas de Língua Portuguesa, foram produzidas em: Moçambique, Angola, Cabo Verde, São Tomé e Príncipe e Guiné Bissau. Se, em consonância com Todorov, considerarmos que "o objeto da Literatura é a própria condição humana, aquele que a lê e a compreende se tornará não um especialista em análise literária, mas um conhecedor do ser humano".

É então que lendo a literatura o outro que quero conhecer se mostra. Uma das grandes características desse tipo de literatura é que os inúmeros escritores africanos quando escrevem optam pela Oralidade da Escrita. Destacamos algumas obras como: O "regresso do morto" do autor moçambicano Suleiman Cassamo e "Luuanda" do escritor José Luandino Vieira nascido em Portugal, mas boa parte de sua vida passou como preso político, por engajar-se pela independência de Angola. 
Toda a vida do personagem era mostrada de maneira peculiar pela estética do próprio uso da oralidade, utilizada pelos escritores. Esse tipo de escrita demonstrava um sentimento de pertencer à África. Eram escritos de forma tão intensa que preferiam atingir dois públicos, e em linhas gerais garantia-se um plurilinguismo que evidenciava a cultura original e a manutenção da língua daquela colonização.

Resultando assim a expressão "entrelugar" onde a morte se fazia presente nesse tipo de Literatura Africanas. E dentro da mesma cultura tem ainda destaque para os velhos, os quais detêm o poder do conhecimento e da sabedoria, passando os costumes e as crenças para as futuras gerações.

A reflexão sobre o papel dos velhos nas sociedades tradicionais africanas, pautada pela noção de Ancestralidade, está presente, também, em "A Varanda do Frangipani”, de Mia Couto, renomado escritor moçambicano, que também é autor dos já consagrados: "Cada homem é uma raça", livro de contos, e "Terra Sonâmbula", que em 2007, foi adaptado para o Cinema.

A partir destas leituras é possível discutir temas como: negritude, colonialismo, aculturação, assimilação, hibridismo linguístico, humor, visão de mundo, tempo e espaço e tradições africanas. Contudo, é impossível encerrar o conhecimento dessas obras, já que essa leitura arranca de nós um olhar de insaciabilidade, de modo que estas abordam aspectos contemporâneos relacionados ao estudo da literatura.

Inicio dos anos de 1930 a 1950 que a intertextualidade se fez mais presente na literatura brasileira, de forma que o poeta moçambicano Luis Carlos Patraquim faz referência a Carlos Drummond de Andrade. Um outro autor denominado Manuel Lopes, cuja obra é Flagelados do Vento Leste, dialoga com Vidas Secas do nosso Graciliano Ramos.

Os elos são imensos entre as literaturas africanas e brasileiras. Os elos são comprovados e dando ênfase quando da afirmação da liberdade, em quaisquer campos: social, político, ético, filosófico, literário e humano. 


\section{O TRATAMENTO MARGINALIZADO DO NEGRO}

É de uma visão distanciada e preconceituosa, cheia de estereótipos no qual distancia o negro de ser defensor de seu próprio discurso e de defesa de sua identidade cultural. E enquanto personagem na literatura o negro ocupa lugar inexpressivo. Para os negros, o período pós abolição não representou a liberdade, poucos tiveram acesso à educação ou alguma forma de instrução.

E no romance Clara dos Anjos de Lima Barreto, o personagem Leonardo Flores, tem semelhante vida ao do seu escritor, que também acaba sem reconhecimento, pobre e na miséria. E ainda quando despontava algum negro, a cor de sua pele era motivo de desdém e preconceito.

O personagem de Lima Barreto estava condenado a sofrer, e a suportar a exclusão social e cultural a que estava sujeito. O personagem representava muitos, privados de direitos, de falar por si e escolher seu futuro.

\section{DA INFLUÊNCIA DO BRASIL NA LITERATURA DE ANGOLA}

A literatura angolana surgiu num período marcado por contestações políticas; pelo despertar da consciência dos africanos e pela luta pela independência das colônias africanas. Tudo isso de certa forma contribuíram para fortalecer as características da literatura angolana, apesar da influência brasileira. Essa influência brasileira foi mais notória num determinado período da literatura angolana, quando os angolanos precisavam descobrir as suas origens e ir em busca dos valores culturais africanos. Nessa época, o Brasil aparece como um pais "irmão", cuja influência cultural sobre muitos angolanos já se fazia sentir desde épocas anteriores. (CUNHA, 2011).

Foi na primeira metade do século XIX que surgiram as primeiras publicações “angolanas", que as condições se tornaram necessárias para acontecer a manifestação do fenômeno literário. Angola foi se colonizando e também se marginalizando de maneira social e econômica, e foi daí que surgiu a necessidade de se criar uma literatura tipica- 
mente angolana. E então em 1948 surge o slogan "Vamos Descobrir Angola” que inicia um novo momento, movimento literário. E deste novo momento faziam parte negros, brancos e mestiços. (CUNHA, 2011).

\section{ENSINO DA LITERATURA AFRICANA E A IDENTIDADE CULTURAL E LINGUISTICA}

É necessário saber que qualquer obra literária é formada por entrelaçamentos de registros linguísticos. Ampliar algumas atividades visando à leitura da literatura como construção de sentidos. A formação do leitor é a grande preocupação de todas as instâncias educacionais para a promoção e principalmente da leitura literária é tarefa árdua.

Candido (1995) nos lembra que a literatura é um direito de todo ser humano. Para ele os direitos humanos referem-se às coisas que são tão indispensáveis para nós quanto para o próximo. Considera ainda que a literatura seja fator indispensável de humanização, por isso acrescenta:

Entendo aqui por humanização o processo que confirma no homem aqueles traços que reputamos essenciais, como o exercício da reflexão, a aquisição do saber, a boa disposição para com o próximo, o afinamento das emoções, a capacidade de penetrar nos problemas da vida, o senso de beleza, a percepção da complexidade do mundo e dos seres, o cultivo do humor. A literatura desenvolve em nós uma quota de humanidade na medida em que nos torna mais compreensivos e abertos para a natureza, a sociedade, o semelhante (CANDIDO, 1995, p. 249 apud ROLON, 2011, p. 133)

Entende-se que se faz necessário estabelecer diálogos entre as literaturas para a promoção e quebra de preconceitos e paradigmas. O leitor precisa perceber que há um enlace entre Brasil, Angola, Moçambique, Cabo Verde e outros países que sofreram com o seu processo de construção social e político.

\section{As RELAÇões ENTRE OS PAÍSES DE LÍNGUA PORTUGUESA E O BRASIL}

As informações históricas sobre as relações literárias entre o Brasil e o império português na África datam já do século XIX, quando o poeta José da Silva Maia Ferreira, autor do primeiro livro africano de que se tem conhecimento - Espontaneidade da minha 
alma: As senhoras africanas (1850) - esteve no Rio de Janeiro. O autor divulgou a verve romântica dos escritores brasileiros, reconhecidamente de Gonçalves Dias, como se pode identificar no seu poema "A minha terra", publicado em 1849.

Apesar de o Romantismo brasileiro já apresentar alguns ecos nas literaturas africanas de língua portuguesa no final do século XIX e no início do século XX, é, nos anos 1930, 1940 e 1950, que a intertextualidade com a literatura brasileira se faz mais evidente. Em Angola, António Jacinto, importante poeta da geração Mensagem, chama atenção para a presença literária brasileira nos jovens poetas angolanos dos anos 50. Costa Andrade, outro escritor angolano, também é incisivo a esse respeito: "Entre a nossa literatura e a vossa, amigos brasileiros, os elos são muito fortes. (...) É fácil ao observador corrente encontrar Jorge Amado e seus Capitães da areia nos nossos melhores escritores. Drummond de Andrade, Graciliano,” (...) (FERREIRA, 1989:141). O poeta Maurício Gomes de Almeida é uma das vozes angolanas desse tempo de busca de uma literatura autenticamente voltada para Angola. Propondo uma ruptura com os cânones lusitanos, funda uma poética, cujo lema era: "Vamos descobrir Angola!" e cujos paradigmas passam a se pautar pelo Modernismo brasileiro.

\section{CONCLUSÃO}

Através da realização da pesquisa do tema abordado foi possível perceber os fortes elos que ligam as literaturas brasileira e africanas de língua portuguesa. De modo nos possibilitou a compreensão que os estudos dessas literaturas devem ser sempre orientados no sentido de proporcionar uma visão de mundo, no campo social, político, existencial, étnico, filosófico, literário e humano.

Desta forma é importante considerar que a escola é um espaço privilegiado para a leitura de obras tão grandiosas como estas, que, sobretudo, proporciona grandes reflexões. Além disso, um povo embora sofrido precisa e merece ter sua própria literatura, lida contada e ouvida. Nesse sentido, através da literatura, os autores encantam e sensibilizam o leitor. 
Diante do exposto é importante salientar que o ensino, pesquisa e extensão deve ser o tripé da formação acadêmica. E a pesquisa e construção de artigos como este, é de grande valia na construção do conhecimento do aluno, proporcionando a estes um aperfeiçoamento do ofício que está sendo construído, habilitando para a vida profissional. Tendo em vista que esse é um espaço de troca de saberes e, por meio dele, se fomenta e incentiva a prática pesquisadora, investigativa e criativa do estudante, formando uma visão mais crítica da realidade.

\section{REFERÊNCIAS}

AGAZZI, Giselle Larizzatti Relações entre os países africanos de língua portuguesa e o brasil na formação das literaturas nacionais. Revista Matter - revista acadêmica da UNIBR - ano 05. Número 10. Volume 01. E - /SSN: 2318-0846. Diponível em: http:// unibr.com.br/revistamatter. Acesso em: 04 de abril de 2018.

\section{CUNHA, Anabela. Influência da literatura brasileira na literatura angolana.}

Revista Angola de Sociologia-RAS - 7/2011, p. 129 a 140. Disponível em: https://journals.openedition.org/ras/1227. Acesso em: 03 de março de 2018.

DUARTE, Eduardo de Assis. O negro na literatura brasileira. Navegações - v. 6, n. 2, p. 146-153, jul./dez. 2013. Universidade Federal de Minas Gerais/CNPq - Minas Gerais - Belo Horizonte - Brasil. Disponível em: http://revistaseletronicas.pucrs.br/ojs/index. php/navegacoes/article/viewFile/16787/10936. Acesso em: 30 de abril de 2018.

FILHO, Domício Proença. A trajetória do negro na literatura brasileira. Estud. av. vol.18 no.50 São Paulo Jan./Apr. 2004. Disponível em: http://dx.doi.org/10.1590/ S0103-40142004000100017. Acesso em: 07 de abril de 2018.

OLIVEIRA, Jurema. Relações literárias entre o Brasil e o Império Português na África. Dimensões, vol. 26, 2011, p. 177-190. ISSN: 2179-8869. UFES - Programa de Pós-Graduação em História. 2011. Disponível em: https://dialnet.unirioja.es/descarga/ articulo/3724748.pdf. Acesso em: 04 de abril de 2018.

SALGADO, Maria Teresa. $\mathbf{O}$ conceito de interferência nas relações literárias entre o Brasil e o Império português em África. Via Atlântica No 8 Dez/2005. Disponível em: www. researchgate.net/publication/237586727_O_conceito_de_interferencia_nas_relacoes_literarias_entre_o_Brasil_e_o_Imperio_portugues_em_Africa. Acesso em: 04 de abril de 2018. 
SECCO, Carmen Lucia Tindó. As Literaturas Africanas de Língua Portuguesa: diálogos com o Brasil. Revista Catedra Digital - 2016 Catedra Unesco PUC - RIO de Leitura. Disponível em: http://revista.catedra.puc-rio.br/index.php/2016/11/03/as-literaturas-africanas-de-lingua-portuguesa-dialogos-com-o-brasil. Acesso em: 03 de abril de 2018.

SILVA, Mauricio. RESENHA: Literatura afro-brasileira: 100 autores do século XVIII ao XX, e Literatura afro-brasileira: abordagens na sala de aula. Sankofa - Revista de História da África e da Diáspora Africana. v. 9, n. 17 (2016). Disponível em: http://www.revistas.usp.br/sankofa/article/view/119066. Acesso em: 04 de abril de 2018.

SOARES, Eliane Veras. Literatura e estruturas de sentimento: fluxos entre Brasil e África. Soc. estado. vol.26 no.2 Brasília May/Aug. 2011. Disponível em: http://dx.doi. org/10.1590/S0102-69922011000200006. Acesso em: 12 de maio de 2018

SOUSA, Denise Dias de Carvalho. As Literaturas Africanas pelo viés do Livro Didático. Revista Trama| Volume 13| Número 30 | Ano 2017 | p. 148 - 167 | e-ISSN 1981-4674. Disponível em: http://e-revista.unioeste.br/index.php/trama/article/viewFile/16480/11869. Acesso em: 04 de abril de 2018. 
doi: 10.48209/978-65-995948-7-4

\section{GAPÍTULO 3}

EDUCAÇĀO:

BREVE REFLEXĀO SOBRE

O PROCESSO DE AVALIAÇĀO

DAAPRENDIZAGEM

Maria Betânia de Oliveira Marques

Ueudison Alves Guimarães 
RESUMO: Este artigo faz uma reflexão sobre a avaliação do processo ensino aprendizagem no âmbito da educação formal. Nesta direção, apresenta os acontecimentos históricos que marcaram a sua trajetória, seu processo teórico e as metodologias desenvolvidas em diferentes momentos da educação. Discorre ainda sobre o rendimento escolar, elaboração de currículo e suas evoluções. Em seguida, reflexiona, de forma breve, sobre as teorias que acompanharam todo processo de ensino aprendizagem - educadores e instituições - , como também, as metodologias de ensinos desenvolvidas durante as avalições do cotidiano escolar. Tivemos como base as leituras das obras de teóricos como: Saul (1999), Luckesi (1994), Hoffmann (1993), entre outros; como também os estudos dos seminários temáticos desenvolvidos em sala de aula. Dessa forma, com o estudo das preposições e resultados das pesquisas bibliográficas - a partir de uma linguagem clara e objetiva - , consideramos que o entendimento aqui exposto é de grande relevância para o processo de profissionalização da profissão docente, por possibilitar uma maior compreensão, contribuindo, assim para nossa formação acadêmica.

Palavras chave: Avaliação da aprendizagem. Processo histórico. Teorias e metodologia.

ABSTRACT: This article makes a reflection on the evaluation of the process education learning in the scope of the formal education. In this direction, it presents the historical events that had marked its trajectory, its theoretical process and the methodologies developed at different moments of the education, still Discourses on the pertaining to school income, elaboration of resume and its evolutions. After that, it reflects, of brief form, on the theories that had folloied all process of education learning - educators and institutions -, as well as, the methodologies of educations developed during the avalições of the daily pertaining to school. We had the readings of the workmanships of theoreticians as: Saul (1999), Luckesi (1994), Hoffmann (1993), among others; as well as the studies of the developed thematic seminaries in classroom. Of this form, with the study of the prepositions and results of the bibliographical research - from a clear and objective language -, we consider thus that the agreement expoxto is here of great relevance for the process of professionalization of the teaching profession, for making possible a bigger understanding, contributing, for our academic formation.

Keywords: Evaluation of learning. Historical process. Theories and methodology.

\section{INTRODUÇÃo}

Ao buscar realizar uma reflexão sobre a avaliação, na perspectiva de uma educação formadora e humanizadora, no processo de ensino-aprendizagem, como também nas relações sociais do indivíduo em seu processo de desenvolvimento, o presente arti- 
go descreve a evolução histórica, teórica e metodológica do referido processo, visando contribuir com informações básicas para educadores e leitores interessados sobre o tema abordado.

Nesta direção, o estudo viabilizou um aprendizado amplo, considerando o exercício da avaliação a em sala de aula, evidenciando a realidade e o conhecimento do educando, como também a prática pedagógica, que proporcionou a uma visão do contexto educacional, oportunizando o conhecimento sobre a intersecção existente entre a teoria e a prática de ensino dos docentes e discentes, que tem a avaliação como um instrumento de inclusão, mediação e diálogo sem deixar de considerar o professor, o aluno e a família.

Vale salientar que, para a elaboração e consolidação do estudo nos apropriamos do material trabalhado pelos professores durante o curso Educação em Direitos Humanos e Diversidade e de leitura das referências indicadas. Contudo, o mesmo foi constituído a partir de uma visão própria do tema e de reflexões realizadas, que se constituíram de embasamento teórico.

Sentimo-nos gratificadas em poder realizar este artigo, pois sabemos que mesmo serviu de grande valia no desenvolvimento de nossa aprendizagem como futuros pedagogos e profissionais capacitados para atuar em uma educação formadora de cidadãos consciente de seus deveres e direitos em uma sociedade democrática.

\section{DISCUSSÃo TEÓRICA}

Segundo Libaneo (1994), a avaliação da aprendizagem escolar é uma atividade didática, pedagógica permanente e necessária ao trabalho docente, pois é através desta que acontece o acompanhamento do processo de ensino e aprendizagem, em que, conforme os objetivos estabelecidos serão comparados os resultados obtidos no decorrer do trabalho conjunto do professor e dos alunos, estabelecido com a finalidade de verificar os progressos, dificuldades e orientar o trabalho para as possíveis soluções necessárias. Nesta direção, a avaliação insere-se não tão somente nas funções didáticas, mas também na própria dinâmica e estrutura do processo de ensino e aprendizagem. 
Desse modo, a avaliação escolar estar para analisar e compreender o processo de ensino e aprendizagem, ajudar na elaboração da proposta pedagógica da escola e garantir que ela seja colocada em prática, isto é, compreender e para fazer a prática escolar de acordo com a realidade na qual a escola está inserida, buscando fundamentar o trabalho pedagógico nos princípios de reflexão sobre suas práticas pedagógicas.

Luckesi (2005) destaca que o papel da avaliação é diagnosticar a situação da aprendizagem, tendo em vista subsidiar a tomada de decisão para a melhoria da qualidade do desempenho do educando. Nesse contexto, a avaliação, segundo o autor, é processual e dinâmica. Na medida em que busca meios pelos quais todos possam aprender o que é necessário para o próprio desenvolvimento, é inclusiva. Sendo inclusiva é, antes de tudo, um ato democrático.

Vale dizer que o tema avaliação da aprendizagem no Brasil, durante muitos anos, ficou defasado, pois se orientou pela produção norte-americana — através do programa de Assistência Brasileiro-Americana ao Ensino Elementar. Somente na década de 1960 é que houve uma maior aquisição de conhecimentos sobre o tema, com professores fazendo cursos a partir de acordos internacionais no exterior.

Salientamos ainda que durante a história do processo de avaliação da aprendizagem o discente foi e continua sendo o principal objeto de estudo no processo avaliativo. Entretanto, até meados dos anos de 1960, o aluno ficava de fora de quaisquer outros objetos como: projetos, programas, materiais curriculares ou qualquer avaliação de instituição educacional.

O movimento dos testes educacionais desenvolvido por Robert Thorndike no início do século XX, na qual ele destaca o valor de mensurar as mudanças comportamentais humanas, desenvolvendo os testes padronizados, introduziu outros instrumentos de avaliação.

Nos anos de 1970 começou-se a ampliar mais objetos de avaliação, como o "Estudo dos Oito Anos" desenvolvido e direcionado por Ralph W. Tyler e Smith, que incluía vários processos avaliativos, como: testes, escalas de atitudes e outros, para medir o grau 
de crescimento em relação aos objetos curriculares. Esse processo passou a ser conhecido como "avaliação por objetivos". Para Tyler (1949, p.105-106), "a avaliação é o processo destinado a verificar o grau em que essas mudanças comportamentais estão ocorrendo".

Nessa proposta de avaliação da aprendizagem, conforme reflexão de Stuffebeam, (1971), fica clara que sua essência é de caráter de controle do planejamento curricular, evidenciando o processo de produção industrial, que se caracteriza pela manipulação matemática dos dados simplista, inflexível e limitada, que deixam de lado outros aspectos no processo de ensino aprendizagem.

Hilda Taba (1962) mantém, também, inalterada a proposta de Tyler, com o mesmo pensamento. Assim sendo, a proposta de elaboração de currículo proposta por Hilda Taba é praticamente a mesma de Tyler. Já Robert F.Mager (1962) implantou um nova sistemática para os objetivos educacionais, os quais eram direcionados por verbos como "permitir" e "proibir".

Em contraponto, James Popham (1969) e Eva Baker (1970), publicaram em 1970 um conjunto de cinco volumes direcionados ao planejamento de ensino e avaliação, evidenciando duas distintas etapas nesses manuais: a orientação da resposta e a prática da resposta, que visava auxiliar o professor nos procedimentos adotados para sua prática em sala de aula.

O registro de manuais de currículo do Brasil feito por Domingues (1985), destaca o modelo de Tyler na obra "Princípios Básicos de Currículo e Ensino" e Hilda Taba com a obra em espanhol: "Elaboractión del Currículo".

A primeira autora brasileira de manual de currículo foi Dalila Sperb que também seguiu as ideias de Tyler. $\mathrm{Na}$ academia esses textos tiveram ascensão com a obra de Victor H. Noll, publicada e traduzida no Brasil em 1965, intitulada de "Introdução às Medidas Educacionais", pois a ideia é um texto prático aos educadores com mudanças desejáveis de comportamento.

Sobre a medida do rendimento do aluno o tema ganha destaque com Ethel Bauzer Medeiros (1971) com a obra "As Provas Objetivas Técnicas de Construção". 
No Brasil, Benjamim Bloom e colaboradores produziram e publicaram no ano de 1983 o "Manual de Avaliação Formativa e Somativa do Aprendizado Escolar", propostas de organizar as melhores técnicas de avaliação, de objetivos educacionais em geral e das principais disciplinas e níveis de educação, sempre com a visão positivista de Tyler, utilizadas por professores e administradores.

No tocante a avaliação de currículo, com uma atenção voltada para mudança neste campo, surge projetos para desenvolver as formas dos programas educacionais. A partir dos anos de 1950, esses estudos aparecem como forma de visar um olhar mais independente prático e analítico para as dualidades de desenvolvimento entre currículo e avaliação de currículo. Esses estudos vêm se constituindo um desafio, pois a repercussão para uma melhor atenção nos estudos avaliativos é registrada há apenas duas décadas.

Ressalta-se que estudiosos como Stuffebeam (1968), Scrivenn (1967), Parlett (1972) e Stake (1967 e 1984) tem dado destaque ao papel do educador, as implicações para o projeto de avaliação, as limitações registradas na literatura, além das contribuições importantes para o modelo de avaliação.

O modelo mais utilizado e divulgado, inclusive oficialmente, foi o de Stuffebeam, cujo enfoque é a tomada de decisão. O primeiro documento de avaliação de currículo divulgado oficialmente pelo Ministério da Educação e Cultura foi o texto de João Batista e Oliveira \& Mariza Rocha e Oliveira, sob o título Afunção da avaliação na tomada de decisões educacionais, preparado em julho de 1973 para o V Encontro de Secretários de Educação e Representantes dos Conselhos de Educação (SAUL,1999, p.35).

Os modelos contemporâneos de avaliação de currículos de Stufflebeam (1968), Scriven (1967), Parlett \& Hamilton (1972) e Stake (1967 e 1984), tinham em comum pontos relevantes previamente definidos com o objetivo de dar destaque aos seguintes pontos:

Enfoque- tendo como principais características fornecer informações da proposta do educador. Definição- que tinha como objetivo de como o autor definia seu processo de avaliação. Objetivo- fornecer informações dentro de uma proposta de avaliação que deveria ser seguido para atingir êxito depois de ser implantado. Papel de o avaliador fornecer- descrever conceituar suas propostas. Implicações para o projeto de avaliação- informações dos autores para definição de uma estrutura de avaliação. Limitações registradas na literatura- 
projetam a tomada de decisões e questionamentos em relação à proposta. Contribuições- focam as importantes contribuições na avaliação nas características que define a proposta (SAUL,1999, p.34).

Entretanto, somente em 1978 uma forma qualitativa de ver a avaliação foi publicada $^{1}$, o primeiro artigo a fazer uma "A abordagem etnográfica: uma nova perspectiva na avaliação educacional".

Com os avanços dos estudos e pesquisa neste campo, em 1984 as questões quantitativas e qualitativas tomaram uma maior ênfase no seminário em Espirito Santo, na cidade de Vitória, cujo tema era Seminário Nacional de Avaliação da Educação.

Vários estudos foram feitos para se chegar às atividades voltadas para professores e alunos, no sentido de uma aprendizagem com direcionamento que pudessem ser colocados em prática trazendo resultados satisfatórios. Um olhar "amoroso"2 por parte dos educadores tem a facilitar as dificuldades ainda num campo pouco explorado.

Ao contrário, a prática da avaliação nas pedagogias preocupadas com a transformação deverá estar atenta aos modelos de superação do autoritarismo e ao estabelecimento da autonomia do educando, pois o novo modelo social exige a participação democrática de todos. (PIAGET apud LUCKESI,1984, p. 32).

As tendências teóricas da história humana da educação, segundo Luckesi (1994, p.54) “estar dividida em duas perspectivas: a redentora que são as pedagogias liberais, e a perspectiva transformadoras que são as pedagogias progressistas”.

Na pedagogia redentora liberal estão: a pedagogia tradicional; a pedagogia renovada progressivista; a pedagogia renovada não-diretiva e a pedagogia tecnicista. $\mathrm{Na}$ pedagogia transformadora progressista, estão: a libertadora; a libertária a critico-social dos conteúdos.

No contexto da pedagogia redentora liberal, a "pedagogia tradicional" compreende as concepções de ensino que segue o ensino humanístico, o ensino "centrado"

1 Como informa o texto, do artigo de Marli E.A. André (Publicações Acadêmicas Brasileiras de 1978).

2 Deixemos claro que não podemos confundir o termo "amoroso" com pieguice de compaixão, o verdadeiro significado é um ato de acolhimento no sentido de orientar. 
no aluno, os conhecimentos são passados como verdades absolutas e o professor é considerado autoridade e completamente sábio não permitindo que os alunos reflitam sobre o assunto, impedindo assim uma comunicação dialógica.

Segundo Luckesi (1994), o papel da preparação intelectual e moral dos alunos com a cultura é para que eles assumam uma posição na sociedade, direção do saber é a mesma para todos, pois os alunos devem superar suas dificuldades. As diferenças de classes sociais não são consideradas e toda a prática escolar não tem nenhuma relação com o cotidiano do aluno. Nestas, o ensino consiste em repassar os conhecimentos, considerando a capacidade de assimilação da criança sendo idêntica à do adulto, a aprendizagem é receptiva, é mecânica recorre a coação exercícios sistemáticos e definição da matéria, sem levar em conta as características próprias de cada idade. Por sua vez, o aluno deve absorver os assuntos expostos através de práticas repetitivas dos exercícios; o aluno deve enxergar o professor uma autoridade em sala de aula, devendo respeitá-lo como tal. Quanto ao professor, este deve exigir do aluno uma postura de interesse, atenção e bom comportamento.

Outra tendência — nesta mesma direção —, é a "pedagogia renovada progressista", em que a escola tem o papel de adequar as necessidades individuais do aluno ao meio social na qual o aluno está inserido e está integração se dá por meio de experiências que devem satisfazer, ao mesmo tempo, os interesses do aluno e as exigências da sociedade, restando como objetivo de a escola ofertar as experiências que permitam ao aluno se educar, num processo ativo de construção e reconstrução permanente. O conteúdo de ensino trata-se de "aprender a aprender", ou seja, é mais importante o processo de aquisição do saber do que o saber propriamente dito. Ensinar de forma "aprender fazendo" está sempre presente. Valorizam-se as tentativas experimentais, a pesquisa, a descoberta, o estudo do meio natural e social, o método de solução de problemas. Na maioria delas, acentua-se a importância do trabalho em grupo não apenas como técnica, mas como condição básica do desenvolvimento mental.

As etapas são: a) colocar o aluno numa situação de experiência que tenha um interesse por si mesma; b) o problema deve ser desafiante, como estímulo à reflexão; c) o aluno deve dispor de informações e instruções que lhe permitam 
pesquisar a descoberta de soluções; d) soluções provisórias devem ser incentivadas e ordenadas, com a ajuda discreta do professor; e) deve-se garantir a oportunidade de colocar as soluções à prova, a fim de determinar sua utilidade para a vida (LUCKESI, 1994, p.58)

Nesta tendência, o papel do professor é auxiliar o desenvolvimento livre e espontâneo da criança, estabelecendo uma consciência democrática de relacionamentos e para a vida em sociedade. Aprender se torna uma atividade de descoberta, é uma autoaprendizagem, sendo a escola um ambiente estimulador. É retido o que se incorpora à atividade do aluno pela descoberta pessoal, a avaliação é continua.

Temos também a "pedagogia renovada não-diretiva", onde a escola tem mais preocupação com a formação de atitudes e com os problemas psicológicos, do que os pedagógicos. O intuito é favorecer a pessoa o autodesenvolvimento e a realização pessoal. O ensino é fundado em facilitar para os alunos que busquem os conhecimentos que consideram indispensáveis para o aprendizado.

Com isso o professor se torna facilitador da aprendizagem, como cita Luckesi (1994, p.60) “ aceitação da pessoa do aluno, capacidade de ser confiável, receptivo e ter plena conviç̧ão na capacidade de autodesenvolvimento do estudante". O professor apenas garante o clima de bom relacionamento pessoal entre todos. A aprendizagem é desenvolvida na própria capacidade do aluno aprender com suas próprias concepções, ou seja, desenvolve sua autoavaliação.

Outra tendência presente no campo da liberal é a "pedagogia tecnicista" em que a escola se torna modeladora do comportamento humano, com técnicas específicas para isso, os conhecimentos são adquiridos apenas como utilidade para necessidades para integrar a máquina do sistema global, dando prioridade ao sistema capitalista atual da época, produzindo assim indivíduos competentes para atuar no mercado de trabalho, Luckesi, 1994.

Para o referido autor, Luckesi (1994, nesta, os conteúdos de ensino apenas competem restritamente informações, princípios científicos e etc., numa sequência lógica. Os métodos são de transmissão e recepção de informações e o bom desempenho é uma 
questão de modificação, segundo Luckesi, (1994, p. 62) "o bom ensino depende de organizar eficientemente as condições estimuladoras, de modo a que o aluno saia da situação de aprendizagem diferente de como entrou".

Em direção oposta - no campo da pedagogia transformadora progressista temos a "pedagogia libertadora" que leva ao aluno a questionar concretamente a realidade das relações do homem com o meio e com outro, onde são denominados "temas geradores", proporcionando uma nova forma de relação com a experiência vivida, redefinindo os conteúdos necessários. Nesta, o professor caminha junto com os alunos fornecendo quando necessário uma informação mais sistematizada, juntos vão construindo uma aprendizagem dialogada, o que se aprende não é memorizado, é sim uma obtenção de conhecimentos críticos e reflexivos ao que concerne ao tema.

Um dos principais inspiradores e divulgador da pedagogia libertadora é Paulo Freire, esta pedagogia que muitos professores tentam colocar em prática no seu dia-a-dia nas escolas.

Outra tendência, neste campo, que se aproxima da tendência progressista libertadora é a "pedagogia libertária". Nesta é eliminado todo tipo de autoritarismo para que os educandos possam declarar seus anseios sem medo. Luckesi (1994) enfatiza uma pedagogia que se posiciona contra qualquer tipo de poder ou autoridade, buscando pessoas e grupos auto gestionários, assim a escola tem o papel de modificar as personalidades e, consequentemente modificar também as instituições, sendo contra a burocracia ou formas de dominação. Segundo Luckesi (1994, p.67) os conteúdos de ensino são colocados à disposição e são postos pelas necessidades e pelos interesses do grupo com a metodologia de autonomia e da liberdade dos estudantes.

As matérias são colocadas à disposição do aluno, mas não são exigidas. São um instrumento a mais, porque importante é o conhecimento que resulta das experiências vividas pelo grupo, especialmente a vivência de mecanismos de participação crítica."conhecimento" aqui não é a investigação cognitiva do real, para extrair dele um sistema de representações mentais, mas a descoberta de respostas às necessidades e às exigências da vida social. Luckesi (1994, p.67). 
Por fim, temos a "pedagogia crítico-social dos conteúdos". Esta pedagogia dá ênfase aos conteúdos, confrontando-os com a realidade social. A mesma está centrada no desenvolvimento da personalidade do indivíduo, compreendendo que não basta ter como conteúdo escolar às questões sociais atuais, mas que o aluno possa se reconhecer nos conteúdos e modelos sociais apresentados para desenvolver a capacidade de processar informações e lidar com os estímulos que lhe estar sendo proposto, buscando ampliar suas experiências e adquirir o aprendizado. Em síntese,

[...] a atuação da escola consiste na preparação do aluno para o mundo adulto e suas contradições, fornecendo-lhe um instrumental, por meio da aquisição de conteúdos e da socialização, para uma participação organizada e ativa na democratização da sociedade (LUCKESI, 1994, p.70)

Neste contexto, o professor passa a ser o mediador, pois ele vai orientar o aluno na relação da troca entre o aluno e o meio. Esta tendência busca favorecer a coerência entre a teoria e a prática, em que o professor verifica o que o aluno já sabe, pois o conhecimento novo se apoia numa estrutura cognitiva já existente. Em meio às diversas tendências existentes no campo da avaliação.

A avaliação da aprendizagem escolar é uma atividade didática, pedagógica permanente e necessária ao trabalho docente, pois é através desse processo que acontece o acompanhamento do processo de ensino e aprendizagem, em que, conforme os objetivos estabelecidos, serão comparados os resultados obtidos no decorrer do trabalho conjunto do professor e dos alunos, com a finalidade de verificar os progressos, dificuldades e orientar o trabalho para as possíveis soluções necessárias. Nesta direção, a avaliação insere-se não só nas funções didáticas, mas também na própria dinâmica e estrutura do processo de ensino e aprendizagem. Desse modo, a avaliação escolar estar para analisar e compreender o processo de ensino e aprendizagem, ajudar na elaboração da proposta pedagógica da escola e garantir que ela seja colocada em prática, isto é, compreender e para fazer a prática escolar de acordo com a realidade na qual a escola está inserida, buscando fundamentar o trabalho pedagógico nos princípios de reflexão sobre suas práticas pedagógicas. 
Luckesi (2005) destaca que o papel da avaliação é diagnosticar a situação da aprendizagem, tendo em vista subsidiar a tomada de decisão para a melhoria da qualidade do desempenho do educando. Nesse contexto, a avaliação, segundo o autor, é processual e dinâmica. Na medida em que busca meios pelos quais todos possam aprender o que é necessário para o próprio desenvolvimento, é inclusiva. Sendo inclusiva é, antes de tudo, um ato democrático.

Em meio às diversas tendências existentes no campo da avaliação da aprendizagem, Segundo Hoffmann (1993, p. 94) e Saul (2000, p. 61) existem pelo menos seis tipos de avaliação, que combinados de uma forma harmônica e adequados para o grupo de alunos, são capazes de compor o processo de avaliação que são eles: avaliação somativa, formativa, diagnóstica, emancipatória, mediadora e dialógica.

Como o próprio nome indica a avaliação somativa, tem como objetivo representar um sumário, uma apresentação concentrada de resultados obtidos numa situação educativa. A avaliação formativa é a forma de avaliação em que a preocupação central reside em coletar dados para reorientação do processo ensino e aprendizagem. A avaliação diagnóstica é aquela que tem dois objetivos básicos: identificar as competências do aluno e adequá-lo num grupo ou nível de aprendizagem. A avaliação emancipatória utiliza-se do senso de autocrítica e autodesenvolvimento do aluno, através de instrumentos como a autoavaliação e a Co avaliação. Nesse modelo, o professor torna-se um tutor e emite suas opiniões através de relatórios do processo evolutivo do aluno. A avaliação mediadora visa prestar muita atenção nas crianças e nos jovens, insistindo em conhecê-los melhor, em entender suas falas, seus argumentos, ouvindo suas perguntas, fazendo-lhes novas e desafiadoras questões no intuito de buscar alternativas para uma ação educativa voltada para a autonomia moral e intelectual. A avaliação dialógica mantém um diálogo entre o educador e o educando, visa promover o desenvolvimento do estudante e incentivá-lo a avançar e procurar formas de transformar o meio em que vive. $\mathrm{O}$ educador age como o mediador, incentivando a integração e a participação, em favor da aprendizagem escolar.

Para Saul (2000), atualmente os objetivos da avaliação visam tanto o processo de aprendizagem quanto os sucessos ou fracassos dos estudantes. Neste sentido, uma dife- 
rença fundamental em relação às provas escolares são as avaliações permanentes, que se realiza com outros meios, entre os quais se incluem o conjunto de tarefas realizadas pelo estudante no decurso do ano escolar. A avaliação é, assim, realizada para obter informação mais abrangente que a simples e pontual referência das provas.

Conforme o mesmo autor, a escola que se almeja, dentro da pedagogia preocupada com a transformação, é a que repensa suas práticas pedagógicas, buscando a inovação, para com o processo de ensino e aprendizagem. A escola existe em função de seus alunos, e cabem a nós, educadores, refletirmos se realmente se respeita os alunos em relação o acesso ao conhecimento e se consideramos quem são eles, de onde vieram em que contexto vive.

Pelo exposto, compreende-se que as práticas de avaliação requerem a compreensão, pelo professor, de que os diversos modelos de ensino e aprendizagem implicam abordagens de avaliação diferenciadas. Neste sentido, as práticas avaliativas através de "prova", que há décadas vem sendo usado no campo educacional, não progrediram no sentido de investigar sobre a aprendizagem em que os alunos se encontram e ainda persistem com a finalidade de apreciar resultados e atribuir notas finais ao invés de servirem de indicadores para ação mediadora do educador.

Segundo Hoffman (2010), as provas prevalecem até hoje na maioria das escolas, porque são importantes instrumentos avaliativos no processo de investigação do desempenho do aluno, uma vez que essas provas não aconteçam quanto à prática de exames, provas parciais, ou únicas, finais, cuja intenção é exclusivamente de "verificar" e "registrar" se o aluno aprendeu ou não o que se pretendia.

Portanto, percebe-se que ainda se vivencia nas práticas atuais a avaliação através de provas com o objetivo de verificar se o aluno aprendeu ou não o conteúdo trabalhado. Todavia, avaliar a aprendizagem escolar, através de diferentes práticas avaliativas, é primordial no sentido de se ter elementos consistentes para orientar os alunos a prosseguirem na busca de novos conceitos, em suas aprendizagens. No entanto, quando isso for 
colocado em prática, a avaliação será vista como função diagnóstica, dialógica e transformadora da realidade escolar.

Porém, sabemos que mudar, muitas vezes, é um processo árduo, já que procedimentos e atitudes avaliativas tradicionais e inadequadas se encontram profundamente enraizados nos professores e alunos.

\section{DISCUSSÃO METODOLÓGICA}

Nosso artigo - Trabalho Científico Final (TCF) — intitulado Educação: Breve Reflexão do Processo de Avaliação da Aprendizagem se constitui requisito para obtenção do título de especialização em Educação em Direitos Humanos e Diversidade. pela Universidade Federal de Alagoas (UFAL). O mesmo é fruto de pesquisas bibliográficas fundamentadas através dos autores citados nas referências — a exemplo da concepção de avaliação segundo as teorias de Cipriano C. Luckesi (2005), Jussara Hoffmann (2010) e Saul (2000). Com este estudo temos o interesse em contribuir com a formação docente, assim como com a prática pedagógica e o processo de avaliação do professor. Nessa direção, ao abordar o tema da Avaliação da Aprendizagem, discorremos sobre seu processo histórico, teórico e metodológico, pois, acreditamos que esta deve fazer parte de nossa formação acadêmica, devendo, também, ser vivenciada em nossa trajetória e prática pedagógica do cotidiano.

O texto que compõe este artigo é uma pequena amostra dos desafios e superações enfrentados até hoje na construção e concepção da educação no que se refere ao tema avaliação educacional.

\section{CONSIDERAÇÕES FINAIS}

Através deste estudo foi possível apreender que a avaliação é parte fundamental na perspectiva de uma educação formadora e humanizadora, no processo de ensino-aprendizagem, como também nas relações sociais do sujeito e na prática pedagógica do professor. Isto posto, segundo Luckesi (2005), "a avaliação deve ser essencialmente formativa, diagnóstica e contínua, pois a mesma é um instrumento fundamental nesse processo". 
Ao imprimir esta forma humanizada de avaliar estaremos formando cidadãos conscientes, críticos, criativos, solidários e autônomos, para uma sociedade justa e igualitária, no que diz respeito ao processo de ensino-aprendizagem, valorizando o indivíduo como um todo.

A reflexões aqui expostas expressam o aprendizado adquirido ao longo das leituras e compreensão dos textos, que resultou num oportuno Trabalho Científico Final do Curso de Especialização em Educação, Direitos Humanos e Diversidade, com um entendimento fundamentado das ideias dos autores investigados, os quais possibilitaram informações importantes e pertinentes para um aprendizado ampliado sobre o tema. Discutir sobre os aspectos históricos e metodológicos da avaliação da aprendizagem, Discutir sobre os aspectos históricos e metodológicos da avaliação da aprendizagem, como também sobre as tendências que regem este processo, é necessário para uma completa apreensão da temática dos direitos humanos e fundamental para o profissional especialista em Especialização de Educação em Direitos Humanos e Diversidade.

Sendo assim, o Trabalho de Conclusão Final abordou a historicidade do surgimento da avaliação, como se deu sua evolução na história da humanidade e as principais teorias de avalição, que para nós é tão importante na contribuição da nossa prática pedagógica em sala de aula como educadores e na formação do profissional.

No entanto, diante da complexidade desse assunto, faz-se necessária a continuidade dos estudos para fortalecimento das ações que promova de fato as mudanças nas práticas de avaliação dos modelos tradicionais tão enraizadas, para formas mais dinâmicas de avaliar.

\section{REFERÊNCIAS}

HOFFMANN, Jussara. Avaliação mediadora: uma prática em construção da pré-escola à universidade - Porto Alegre: Editora Mediação, 1993. 20ª Edição revista, 2003.

HOFFMAN, Jussara. Avaliar: respeitar primeiro, educar depois / Jussara Maria Hoffmann. Porto Alegre: Mediação, 2010. (2 $2^{\mathrm{a}}$ Ed. Atual. Ortog.). 
LIBÂNEO, José Carlos. Didática. São Paulo: Cortez, 1994.

LUCKESI, Cipriano Carlos. Filosofia da educação - São Paulo: Cortez, 1994.

LUCKESI, Cipriano Carlos. Avaliação da Aprendizagem Escolar. $17^{\mathrm{a}}$ ed. São Paulo, SP: Cortez, 2005.

SAUL, Ana Maria. Avaliação Emancipatória: desafios á teoria e á prática de avaliação e reformulação de currículo 4a edição - São Paulo, Cortez, 1999.

SAUL, Ana Maria (org). Paulo Freire e a formação de educadores. São Paulo, Editora articulação Universidade/escola, 2000. 
doi: 10.48209/978-65-995948-7-5

\section{GAPÍTULO 4}

CONSCIENTIZAÇĀODOS RIBEIRINHOS SOBRE A IMPORTÂNCIA DA

PRESERVAÇĀO AMBIENTAL

\section{DORIOMANSO}

Leidiane Aparecida dos Santos

Ueudison Alves Guimarães 
RESUMO: O presente artigo apresenta uma reflexão sobre como se pode relacionar e preservar de forma coesa, sem prejuízos para ambas as partes na questão em que envolve Educação Ambiental e uso dos recursos hídricos junto à modernização e desenvolvimento da construção de casas as margens do rio Manso, conhecido também como rio das Mortes. Os dados foram coletados a partir de questionários, palestras e visitas realizadas aos ribeirinhos que residem às margens do rio. Foram realizados estudos de conscientização com os residentes. Em cada pesqueiro foram realizadas as intervenções com os moradores propiciando um aprendizado presente e futuro sobre a importância da preservação do meio natural. Os resultados obtidos foram significantes, pois ajudarão na modificação do modo de ver os fatos e, por conseguinte isto pode levar a uma mudança de pensamentos e atitudes de vários ribeirinhos com relação a preservação das margens do rio, evitando futuros problemas ambientais.

Palavras-chave: Educação Ambiental, Modernização, Ribeirinhos, Aprendizado, Meio Natural.

ABSTRACT: This article presents a reflection on how it can be related and preserved in a cohesive way, without prejudice to both parties in the issue that involves Environmental Education and the use of water resources along with the modernization and development of the construction of houses on the banks of the Manso River, also known as the River of Deaths. Data were collected from questionnaires, lectures and visits to riverside dwellers who live on the banks of the river. Awareness studies were carried out with residents. In each fishery, interventions were carried out with the residents, providing a present and future learning about the importance of preserving the natural environment. The results obtained were significant, as they will help to change the way of seeing the facts and, therefore, this can lead to a change of thoughts and attitudes of several riverside people in relation to the preservation of the river banks, avoiding future environmental problems.

Keywords: Environmental Education, Modernization, Riverside, Learning, Natural Environment.

\section{INTRODUÇÃo}

Este artigo tem como objetivo mostrar a importância do rio Manso para o município de Nova Nazaré-MT e consecutivamente aos ribeirinhos que residem à sua margem. Sendo que o rio é formado por uma complexa e variada biodiversidade que precisa ser preservada para manter sua originalidade natural. 
Alvarenga (2004) ressalta que, as matas ciliares também conhecidas como vegetação ripária ou de galeria, consistem na flora existente às margens de cursos d'água. Essa vegetação ajuda na manutenção da qualidade da água e da estabilidade do solo para evitar processos erosivos, proteção dos cursos d'água do rio e fornecimento de alimento para os seres aquáticos e terrestres. Contribuem também para manter a estabilidade térmica da água e permitem a criação de caminhos para os animais silvestres.

Trabalhos e estudos voltados à preservação, recuperação e manutenção de matas ciliares são relevantes, considerando que a destruição destas áreas gera impactos na vida da população dependente desse equilíbrio ambiental, afetando todo um ciclo de vida situado nesta localidade. Devemos ter a ciência sobre a importância de passarmos aos ribeirinhos métodos e maneiras educacionais voltados para a preservação do meio natural no qual ele está inserido.

Nesse contexto, a compreensão das interações homem-natureza e de seus impactos pode ocorrer através da percepção ambiental, que permite a obtenção de conhecimentos socialmente elaborados e compartilhados, capazes de contribuir para a construção de uma nova realidade (JODELET, 2001). A percepção ambiental tem se destacado como fenômeno que associa a psicologia com a sociologia e a ecologia, auxiliando na compreensão das expectativas, satisfações e insatisfações da população no tocante ao meio ambiente e aos ecossistemas, relacionados à qualidade de vida e bem-estar social (OKAMOTO, 1996).

Macedo (2005) especifica que, o uso da percepção ambiental permite identificar como o homem se relaciona com a natureza, compreendendo o grau de conscientização do mesmo, em relação à problemática ambiental.

Nessa circunstância, o presente ensinamento tem por objetivo analisar as percepções e relações que os moradores do entorno e das proximidades do rio Manso apresentam em relação à mata ciliar, bem como sua importância e fragilidade.

Nossa geração tem testemunhado um crescimento econômico e um processo precedente, os quais, ao tempo em que trouxeram benefícios para muitas pessoas produzi- 
ram também sérias consequências e ambientais sociais. [...] É absolutamente vital que os cidadãos de todo o mundo insistam a favor de medidas que darão suporte ao tipo de crescimento econômico que não traga repercussões prejudiciais para as pessoas, que não diminuam, de nenhuma maneira, as condições de vida e de qualidade do meio ambiente. É necessário encontrar meios de assegurar que nenhuma nação cresça ou se desenvolva às custas de outra nação, e que indivíduo aumente o seu consumo à custa da diminuição do consumo dos outros. Os recursos do mundo deveriam ser utilizados de um modo que beneficiasse toda a humanidade e proporcionasse a todos a possibilidade de aumento de qualidade de vida. Nós necessitamos de uma nova ética global (CARTA DE BELGRADO apud DIAS, 2004, p.101-102).

Este registro, define-se que a Educação Ambiental deve ser multidisciplinar, continuada, integrada às diferenças da região inserida e voltada para os interesses da área estudada, permitindo que os ribeirinhos passam a analisar os impactos que uma sociedade gera sobre as outras e sobre o ambiente global.

A reforma dos processos e sistemas educacionais é central para a contratação dessa nova ética de desenvolvimento e ordem econômica mundial. Governantes e planejadores podem ordenar mudanças e novas abordagens de desenvolvimento que possam melhorar as condições do mundo, mas tudo isso não se constituirá em soluções de curto prazo se a juventude não receber um novo tipo de educação. Isso vai requerer um novo e produtivo relacionamento entre estudantes e professores, entre a escola e a comunidade, entre o sistema educacional e a sociedade (CARTA DE BELGRADO apud DIAS, 2004, p.103)

Considerando o importante papel desempenhado pelas matas ciliares e pela água em nossas vidas, não é difícil imaginarmos os inúmeros e quase incalculáveis prejuízos que a destruição das matas e a falta da água pode causar para os seres vivos. Além dos problemas de saúde, temos a desertificação do solo, assoreamento dos rios e posteriormente causando também uma redução na produção dos alimentos que são utilizados na maioria das vezes para a própria subsistência dos moradores. 
De acordo com Martins (2009 apud DIAS, 2000), Educação Ambiental é definida como um processo no qual as pessoas aprendem como funciona o ambiente, como dependemos dele, como podemos interferir em seu equilíbrio e de que maneira podemos minimizar nossa interferência nesse sistema. Esta é um forte instrumento para garantir uma conservação futura dos recursos hídricos. Nos dias atuais, os indivíduos devem estar preparados para avaliar e identificar problemas ligados à questão ambiental.

Diante do trabalho exposto, pode-se dizer que um dos maiores instrumentos de controle da preservação das matas ciliares e qualidade da água do rio é a conscientização da população através da Educação Ambiental. Ressaltar também, que a escola é o principal veículo para informar e formar cidadãos conscientes que possuam um comportamento participativo para aderir métodos de Educação Ambiental.

Um objetivo fundamental da Educação Ambiental é lograr que os indivíduos e a coletividade compreendam a natureza complexa do meio ambiente natural e do meio criado pelo homem, resultante da integração de seus aspectos biológicos, físicos, sociais, econômicos e culturais, e adquiram os conhecimentos, os valores, os comportamentos e as habilidades práticas para participar responsável e eficazmente da prevenção e solução dos problemas ambientais e da gestão da questão da qualidade do meio ambiente. [...] Para a realização de tais funções, essa educação deveria ter uma vinculação mais estreita entre os processos educativos e a realidade, estruturando suas atividades em torno dos problemas concretos que se impõem à comunidade; e enfocar a análise de tais problemas, através de uma perspectiva interdisciplinar e globalizadora, que permita uma compreensão adequada dos problemas ambientais (Dias, 2004, p.107).

Portanto, o presente projeto buscou levar conscientização com relação ao tratamento dado aos recursos hídricos. Na fase de formação, moradores devem ser preparados para lidar com os problemas ambientais que são cada vez, evidentes e pertinentes para a comunidade.

O artigo tem como visão consistir, valorizar e informar os moradores que residem 
às margens do rio Manso, sobre a importância da preservação das matas ciliares, qualidade da água, reconhecer a importância dos recursos hídricos, diagnosticar e classificar as condições básicas do recurso hídrico de sua comunidade, estudar as maneiras de conservação e preservação dos recursos hídricos, propor, desenvolver e aplicar a Educação Ambiental demonstrando problemas cotidianos relacionados às matas ciliares e água, incentivar os moradores a desenvolver princípios e maneiras que contribuem para o desenvolvimento da Educação Ambiental.

A educação Ambiental não deve ser tratada como algo longe da rotina dos ribeirinhos, mas como parte inerente de suas vidas. É de suma importância a conscientização da preservação do Meio Ambiente para a nossa vida e todos os seres vivos, afinal vivemos nele e necessitamos que todos os seus recursos naturais sejam sempre puros e preservados. A compreensão quanto a essa preservação deve ser repassada as pessoas mais idosas moradoras à margem do rio, dando prioridade para iniciar mais cedo com seus descendentes, pois é muito mais fácil fazer as crianças entenderem a importância da natureza e quando esse ensinamento inicia logo, elas com certeza vão crescer com essa ideia bem formada. Desenvolvi as atividades com os moradores de maneira bem superficial e interdisciplinar priorizando a participação e entendimento de todos.

Segundo Loureiro (2006), por meio da participação da sociedade é possível ampliar a relação educação-ambiente, onde estamos inseridos e de que somos parte, buscando alternativas para os problemas socioambientais. Neste conceito, a participação da comunidade é muito importante nas práticas da Educação Ambiental. Tendo uma visão de diferentes valores para que a comunidade inserida compreenda com clareza a importância de se fazer praticas educativas, buscando sanar danos futuros ao meio natural.

Segundo Trevisol (2010), diante da complexidade ambiental, o conhecimento é extremamente importante na construção de novos valores, novas autonomias, tanto no sentido de instigar as atitudes, bem como, de acentuar a compreensão das relações entre a humanidade e a qualidade ambiental. 
A compreensão, conscientização e sensibilidade da sociedade estudada juntamente com a inserção da Educação Ambiental em relação a preservação da mata ciliar, buscando adquirir uma nova visão de sustentabilidade, mantendo o equilíbrio do meio natural, tendo uma vida saudável dos moradores e do próprio ecossistema.

De acordo com Morin (2000), o enfraquecimento da visão global conduz a diminuição da responsabilidade da sociedade, onde cada cidadão se torna responsável apenas por suas ações, desfazendo-se seus vínculos com a humanidade e, consequentemente despreocupar-se com o bem-estar de todos. Com isso, cada cidadão não deve apenas pensar em si, visto que este está inserido na sociedade e, esta necessita de ações em benefício de todos, bem como do ecossistema. Ainda, de acordo com o autor, o aumento da problemática ambiental resulta da expansão da tecnologia e do crescimento populacional, pois atualmente percebemos que, quanto mais um determinado local se desenvolve, mais degradação ocorre.

Para reduzir os danos ambientais há o surgimento de estudos, práticas e maneiras, que podem proporcionar uma harmonia equilibrado entre os ribeirinhos e o meio ambiente, buscando a preservação e manutenção dos recursos naturais.

\section{MATERIAL E MÉTODO}

\section{ÁREA DE ESTUDO}

A pesquisa e palestra foi realizada às margens do rio Manso, localizado a 10 quilômetros do município de Nova Nazaré-MT. Sendo uma área com grande potencial turístico. Possuindo uma infraestrutura voltada para o atendimento de turistas com grande número de pesqueiros para lazer, e tem como principal característica a pesca, importante para a sobrevivência de muitos de seus moradores locais.

A região, na qual está inserida a área de estudo, encontra-se sobre o clima tropical, com verão chuvoso e inverno seco. Devido às características físicas da região, e os remanescentes de vegetação, define que a vegetação original do local é formada pelo Cerrado. 


\section{INSTRUMENTO E PROCEDIMENTOS PARA COLETA DE DADOS}

O referido estudo foi realizado em duas etapas com procedimentos sistemáticos para obtenção de dados e a análise histórica e cultural da relação dos ribeirinhos com o rio.

A primeira etapa foi realizada uma pesquisa onde participaram 20 moradores entre 18 e 60 anos. Foram aplicadas entrevistas, entre os meses de janeiro a junho de 2018, constituídas por 15 questões estruturadas, as quais abordaram aspectos relacionados à percepção que os moradores apresentam no que rege às modificações no uso das matas ciliares, importância do rio, destino de resíduos e alterações na paisagem. A análise da percepção ambiental dos ribeirinhos ocorreu por meio da identificação em seus discursos, da importância que este recurso hídrico representa para sua comunidade.

Para Boni (2005), o método de entrevistas, é utilizado quando se deseja obter o maior número possível de informações sobre determinado tema e também para obter um maior detalhamento do assunto em questão. A técnica de entrevistas atende principalmente finalidades exploratórias, sendo bastante utilizada para o detalhamento de questões e formulação mais precisas dos conceitos relacionados.

Na segunda etapa foi realizada uma palestra para toda a população ribeirinha, tendo apoio e participação ativa da Secretaria do Meio Ambiente do município, onde a mesma disponibilizou biólogos para ministrar os ensinamentos aos moradores.

\section{RESULTADOS E DISCUSSÕES}

\section{DEFINIÇÃO DA POPULAÇÃO DE ESTUDO}

Constatei que, na maioria, os entrevistados são economicamente ativos e trabalham em outros municípios. A maioria dos entrevistados residem em outros munícipios, e a minoria reside às margens do rio. Em relação ao grau de escolaridade poucos moradores possuem curso superior, sendo que a maior parte tem apenas o ensino médio e fundamental, existindo também alguns analfabetos. 
Os entrevistados em grande parte residem nos pesqueiros durante finais de semanas ou feriados, sendo poucos os que moram devidamente no local, pagando uma pessoa para cuidar do terreno, na qual efetuaram melhorias. Quando questionados sobre a aquisição de seus pesqueiros, foram unânimes em dizer que o terreno é próprio por compra e todas as residências possuem acesso à energia elétrica.

\section{USO DO RIO E SUA RELAÇÃO AMBIENTAL}

Em relação ao destino do lixo, todos os entrevistados afirmam que existe coleta na localidade feita pela prefeitura municipal. A coleta é feita somente para o lixo seco produzido sendo os próprios moradores responsáveis pelo lixo orgânico produzido.

Muitas famílias relataram que queimam o lixo orgânico o que acaba poluindo o solo, meio ambiente e o leito do rio, outras fazem o procedimento correto produzindo adubo orgânico usado em plantações de verduras e legumes para seu consumo.

A educação ambiental na escola é um instrumento eficaz para criar e aplicar formas sustentáveis de interação entre o homem e a natureza (SANTOS, 2007 e CUBA, 2010) e se apresenta como desafio nas reflexões proporcionadas pela escola (ZAKRZEVSKI, 2004).

A utilização do adubo orgânico, produzido com lixo doméstico, aumenta as propriedades físicas, químicas e biológicas do solo na produção de diferentes gêneros alimentícios. Entretanto, alguns ribeirinhos consideram a utilização de agrotóxicos como método mais alternativo e eficaz, levando o desperdício do lixo orgânico pela queima do mesmo acarretando danos ao meio natural.

De acordo com Machado (2003, p.131), a base empírica do conhecimento local da população sobre os rios de uma bacia hidrográfica deve ser valorizada, devido ao fato de possuir um forte valor socioambiental, pois a água faz parte da história dos indivíduos e da comunidade, ganhando sentidos simbólicos e culturais.

Infelizmente, em pleno século XXI, moradores locais, poder público e empresas privadas não levam em consideração conceitos básicos de preservação ao meio natural. 
Muitos moradores acabam construindo suas residências muito próximo às margens do rio danificando drasticamente a mata ciliar.

Segundo Ferreira, D. T. A. M. (2014, p. 82), "a falta de conhecimento e planejamento na instalação de alguns empreendimentos, associada a uma gama de normas técnicas que ignoram as relações simbólicas dos ribeirinhos com seu ambiente de construção cultural, acarreta inúmeras perdas como: o sofrimento gerado pela perda da paisagem, a falta de recursos naturais de uso cotidiano como a água, e às vezes a necessidade de mudar de seu local natural"

A falta de mata ciliar na beira do rio são um dos problemas encontrados no local, respeitando cada vez menos as margens dos rios, logo quando chove todo os poluentes e resíduos são jogados diretamente no leito do rio, aumentando drasticamente sua poluição, e causando cada vez mais o assoreamento, um problema grave que muitos rios brasileiros vêm passando.

\section{MUDANÇAS NA PAISAGEM NATURAL E IMPORTÂNCIA DA MATA CILIAR}

Grande porcentagem dos entrevistados (80\%) aponta alterações no meio natural e na mata ciliar nas proximidades de seus terrenos, enquanto $20 \%$ alegaram não ter visto qualquer alteração na paisagem local. Os moradores, relataram que as mais expressivas alterações ocorridas no meio natural, foram produzidas pela derrubada da mata para instalação de moradias e construção de portos para desembarque e embarque de canoas e passagem para descer a margem do rio.

A maioria dos ribeirinhos do rio Manso (85\%), ao serem questionados se sabiam o conceito de matas ciliares, tiveram total segurança ao confirmarem ter conhecimento do tema. E muitos deles revelaram conhecer a função desta formação vegetal natural.

Tomando como base as respostas dos moradores do rio Manso, percebi que a maioria deles tem noção da importância e das funções que a mata ciliar exerce, porém apresentam dificuldade em cita-las e acabam destruindo para construir suas residências. 
Tendo muito o que aprender sobre métodos e maneiras para sanar de vez o desmatamento da mesma.

A proposta tem como base o diálogo e a educação ambiental, visando a articulação e organização do núcleo municipal e a implementação de apoio a Educação Ambiental juntos aos moradores. A proposta busca ações conjuntas entre a sociedade e o poder público, seguindo as seguintes especificações:

Reforçar a construção política da relação das Prefeituras Municipais em torno do Comitê e da participação efetiva das mesmas na implementação do processo de gestão dos recursos hídricos; organização de equipe dirigida à formação e capacitação de agentes ambientais e de recursos hídricos oriundos da comunidade, em conjunto com cada um dos municípios; campanha de mobilização social envolvendo a comunidade em geral e os escolares nas atividades de gestão ambiental e de recursos hídricos; distribuição de materiais com o objetivo de educação ambiental (DOTTO, 2009, p.74).

Os resultados revelam que muitos ribeirinhos retiram árvores das margens do rio, por falta de conhecimento e conscientização e acabam pensando apenas em construir suas casas próximas a margem do rio para facilitar seu acesso.

A educação ambiental não deve apenas informar e construir um senso de responsabilidade, mas também mudar o comportamento das pessoas, criando maneiras e práticas que atitudes sejam efetivas na sociedade. A escolarização de membros da família do grupo pesquisado, é condizente com a visão que eles possuem sobre a importância das matas ciliares, na drenagem das águas do rio Manso. A informação é socializada entre os membros da família (ALTIN, et al., 2013).

\section{CONSIDERAÇÕES FINAIS}

Conclui que os ribeirinhos que residem a margem do rio Manso, localizado no município de Nova Nazaré - MT, têm conhecimento de que a presença da mata ciliar é importante para preservação do meio natural e evitar futuros desastres ambientais. No, contudo, a implantação de práticas que resulta na preservação da vegetação do entorno 
do rio, não está sendo desenvolvida por muitos dos moradores estudados.

Os moradores afirmam que o mencionado recurso hídrico que os cerca, será imprescindível no futuro, revelando que a falta de cuidado pode gerar consequências futuras, tornando-se sério motivo de preocupação.

Maioria dos ribeirinhos principalmente os que têm um tempo menor de moradia no local, se preocupam menos com a preservação ambiental do espaço destruindo de forma abusiva as matas ciliares que protegem o rio, construindo casas muito próximo da margem do curso de água corrente prejudicando o meio natural.

Poucos moradores têm conscientização de preservar a mata ciliar, tendo destaque aqueles que possuem um conhecimento mais sofisticado em relação a preservação e manutenção da formação vegetal original.

Tenho como sugestão que o governo Estadual e Municipal crie métodos para incentivar esses moradores a terem uma conscientização maior pela preservação das matas ciliares e diminuírem os agentes poluidores jogados no leito do rio, além de criarem Políticas Públicas para fortalecer a fiscalização nas áreas mais prejudicadas pela sociedade.

\section{REFERÊNCIAS}

ALTIN, A. et al. Environmental awareness level of secondary school students: A case study in Balıkesir (Türkiye). Procedia - Social and Behavioral Sciences, p 1208-1214, 2014.

ALVARENGA, A. P. 2004. Avaliação inicial da recuperação de matas ciliares em nascentes, 194f. Dissertação (Mestrado em Engenharia Florestal) UFL, 2004.

BONI, V.; QUARESMA, J. Aprendendo a entrevistar: como fazer entrevistas em Ciências Sociais. Tese - Revista eletrônica dos pós-graduandos em sociologia política da UFSC. Santa Catarina, v. 2, n. 1, p. 68 - 80, 2005.

CUBA, M. A. Educação ambiental nas escolas. ECCOM, v. 1, n. 2, p. 23-31, 2010. 
DIAS, Genebaldo Freire. Educação Ambiental: Princípios e Práticas. $9^{\circ}$ ed. São Paulo: Gaia, 2004. 541 páginas.

DOTTO, Carlos R. D. Histórico da Construção da Proposta da "REA Vacacaí" - Período de 2000 a 2009 - REA - Rede de Educação Ambiental da Bacia Hidrográfica dos rios Vacacaí e Vacacaí-Mirim. Universidade Federal de Santa Maria, Centro de Ciências Rurais. Santa Maria/RS, 2009.

FERREIRA, D. T. A. M.; MARQUES, E. E.; BUENAFUENTE, S. M. F.; SOUZA, L. B.; GRISON, M. da. G.; LIMA, A. M. T. de. Perdas simbólicas e os atingidos por barragens: o caso da Usina Hidrelétrica de Estreito, Brasil. Desenvolvimento e Meio Ambiente, Curitiba, v. 30, p. $73-87,2014$.

JODELET, D. Representações sociais: um domínio em expansão. In: JODELET, D. (Org.) As representações sociais. RJ. EDUERJ. 2001.

LOUREIRO, C. F. B. Problematizando conceitos: contribuições a práxis em educação ambiental. In: Pensamento complexo, dialética e educação ambiental. São Paulo: Cortez, 2006.

MACEDO, R. L. G. Percepção, conscientização e conservação ambientais. Lavras: FAEPE, 2005.

MACHADO, C. J. S. Recursos Hídricos e Cidadania no Brasil: Limites, Alternativas e Desafios. Ambiente e Sociedade, São Paulo, v. VI, n. 2, p. 121 - 136, 2003.

MARTINS, S. V. Recuperação de matas ciliares. Viçosa: Aprenda Fácil, 2001.

MORIN, Edgar- Os sete saberes necessários à educação do futuro / Edgar Morin; tradução de Catarina Eleonora F. da Silva e Jeanne Sawaya; revisão técnica de Edgard de Assis Carvalho. - 2. ed. - São Paulo: Cortez; Brasília, DF : UNESCO, 2000.

OKAMOTO, J. Percepção Ambiental e Comportamento. São Paulo: Plêiade, 1996, $200 p$.

SANTOS, E.T.A. 2007. Educação ambiental na escola: conscientização da necessidade de proteção da camada de ozônio. [dissertação]. 53 f. Curso de Pós-Graduação em Educação Ambiental da Universidade Federal de Santa Maria. Santa Maria. 2007. 
TREVISOL, J.V. et al.; A Educação Ambiental em Bacias Hidrográficas: uma experiência nas escolas públicas do Rio do Peixe (SC). Rev. eletrônica Mestr. Educ. Ambient. ISSN 1517-1256, v. especial, 2010.

ZAKRZEVSKI, S. B.; SATO, M. Sustentabilidade do meio rural: empoderamento pela educação ambiental. Perspectiva, Erechim, v. 28, n. 101, p. 7-16, 2004. 
doi: 10.48209/978-65-995948-7-6

\section{GAPÍTULO 5}

O LÚDICOCOMO

\section{ELEMENTOMOTIVADOR} NA EDUCAÇĀODAS

CRIANCCAS DOCAMPO

\section{EM ATALAIA - AL}

Maria Betânia de Oliveira Marques

Ueudison Alves Guimarães 
RESUMO: Este artigo faz uma reflexão sobre o lúdico como elemento motivador no processo ensino aprendizagem das crianças, no âmbito da educação do campo. Nesta direção, apresenta alguns elementos históricos que marcaram a trajetória da educação do campo no Brasil. Apresenta-se aqui os aspectos principais de uma pesquisa bibliográfica que foi realizada pelas pesquisadoras, tendo como foco a questão da ludicidade na infância do campo, e a escola enquanto espaço que pode ou não propiciar a vivência dessa ludicidade. Buscamos, desta forma, fazer um breve levantamento em torno de pesquisas já realizadas sobre o tema em tela, incorporando também a leitura de autores como Brougère (1998), Caldart (2004), Pires (2012), Vigostky (1988), entre outros. O que apresentamos aqui, então, são algumas reflexões em torno da literatura estudada, em diálogo com as informações que nossa incursão em campo nos deu sobre o espaço do lúdico em uma Escola do Campo no município de Atalaia-AL, envolvendo professores e alunos do segundo e terceiro anos do Ensino Fundamental I. Dessa forma, com o estudo e resultados das pesquisas de campo e bibliográfica concluiu-se que, por meio das atividades lúdicas, a criança comunica-se consigo mesma e com o mundo onde está inserida, constrói conhecimentos, desenvolvendo-se integralmente enquanto ser social e culturalmente na sociedade. Partindo desse pressuposto entendemos que os indivíduos estão sempre aprendendo coisas novas em seu convívio com seus semelhantes no meio em que está inserido. Entretanto, ainda que precisemos salientar que as observações se deram em um curto intervalo de tempo, encontramos contradições nos relatos das professoras entrevistadas sobre a importância do lúdico articulado ao processo de ensino aprendizagem. Ainda assim, reafirmamos as atividades lúdicas enquanto uma das ferramentas mais eficazes, para o envolvimento e desenvolvimento do aluno na aprendizagem escolar.

Palavras chave: Educação do Campo, Lúdico, Aprendizagem

ABSTRACT: This article reflects on play as a motivating element in the teaching-learning process of children, within the scope of rural education. In this direction, it presents some historical elements that marked the trajectory of rural education in Brazil. We present here the main aspects of a bibliographical research that was carried out by the researchers, focusing on the question of playfulness in rural childhood, and the school as a space that may or may not provide the experience of this playfulness. In this way, we seek to make a brief survey of research already carried out on the subject in question, also incorporating the reading of authors such as Brougère (1998), Caldart (2004), Pires (2012), Vigostky (1988), among others. What we present here, then, are some reflections on the literature studied, in dialogue with the information that our incursion into the field gave us about the playful space in a Campo do Campo in the municipality of Atalaia-AL, involving teachers and students from the second and third years of Elementary School I. Thus, with the study and results of field and bibliographic research, it was 
concluded that, through playful activities, the child communicates with himself and with the world where he is inserted, builds knowledge, fully developing as a social and cultural being in society. Based on this assumption, we understand that individuals are always learning new things in their interaction with their peers in the environment in which they are inserted. However, even though we need to point out that the observations took place in a short period of time, we found contradictions in the reports of the teachers interviewed about the importance of playfulness articulated in the teaching-learning process. Even so, we reaffirm recreational activities as one of the most effective tools for student involvement and development in school learning.

Keywords: Rural Education, Playful, Learning

\section{INTRODUÇÃo}

O tema que propusemos para nosso Trabalho de Conclusão do Curso de Pedagogia está voltado para a Educação do Campo. Tal proposta se consolidou cursando a disciplina eletiva Educação do Campo no Curso de Pedagogia. Diante dos temas ministrados nas aulas e após uma aula de campo no Município de Arapiraca-AL, pudemos entender, durante estudos de textos e discussões em sala de aula, que muitas localidades ficam a mercê de uma educação escolar precária, porém não é o caso desta citada.

Ao entrar na Universidade Federal de Alagoas, tivemos já a intenção de fazer nosso TCC com o tema voltado para o lúdico, mas fomos sendo contagiadas por inquietações a respeito da Educação do Campo e assim resolvemos juntar essas duas propostas que acabaram se completando. Ao cursarmos a disciplina de Jogos, Recreação e Brincadeiras, se reafirmou essa motivação de conhecer cada vez mais a ludicidade, com o intuito de identificar as contribuições do lúdico para o desenvolvimento dos alunos, respeitando suas especificidades culturais.

A proposta de investigar o lúdico como elemento motivador para o ensino aprendizagem se explica porque o mesmo impulsiona o desejo de satisfazer as necessidades do ser humano.

Partimos do pressuposto que a utilização do lúdico no ensino fundamental seja essencial em nossas aulas, com uma maior participação dos educandos, para que não 
fiquem só centradas no professor, sendo o aluno o personagem principal do processo de ensino-aprendizagem.

Aprender se torna uma atividade de descoberta, é uma autoaprendizagem, devendo ser a escola um ambiente estimulador.

As etapas são: a) colocar o aluno numa situação de experiência que tenha um interesse por si mesma; b) o problema deve ser desafiante, como estímulo à reflexão; c) o aluno deve dispor de informações e instruções que lhe permitam pesquisar a descoberta de soluções; d) soluções provisórias devem ser incentivadas e ordenadas, com a ajuda discreta do professor; e) deve-se garantir a oportunidade de colocar as soluções à prova, a fim de determinar sua utilidade para a vida. (Luckesi,1994: p.58).

Nesse processo de aprendizagem o professor é de suma importância, pois ele é o facilitador na disponibilização dos espaços e nas mediações dos jogos e brincadeiras, ou seja, ele é o mediador na construção do conhecimento.

O jogo não pode ser visto apenas como divertimento ou brincadeira para desgastar energia, pois ele favorece o desenvolvimento físico, cognitivo, afetivo e moral. (Piaget, 1967: p.25).

Sendo assim se faz necessário que o professor saiba como trabalhar em sua sala de aula com atividades lúdicas, desde as atividades que pode proporcionar para seus alunos como também ele poderá participar desse momento com os alunos não deixando a brincadeira como algo a parte das atividades curriculares.

Portanto, é importante que os educadores estejam cientes de que a brincadeira é necessária, por trazer grandes contribuições no desenvolvimento das habilidades dos seus educandos. Podemos observar isto ao utilizar atividades lúdicas em nossas salas de aula, pois percebemos que os alunos geralmente ficam mais atentos nas atividades que estão sendo propostas pelo professor.

A Resolução $n^{0}$ 2, de 28 de abril de 2008, que estabelece diretrizes complementares, normas e princípios para o desenvolvimento de políticas públicas de atendimento da Educação Básica do Campo, evidencia que a Educação do Campo deve ser voltada para o campo, de forma específica e diferenciada, contemplando a realidade comunitária. 
Quem vive no campo não deve ser obrigado a se deslocar para estudar e ter acesso a uma educação de qualidade. Conforme cita Resolução n ${ }^{\circ}$ 2, de 28 de abril de 2008:

\begin{abstract}
Art. $3^{\circ}$ A Educação Infantil e os anos iniciais do Ensino Fundamental serão sempre oferecidos nas próprias comunidades rurais, evitando-se os processos de nucleação de escolas e de deslocamento das crianças, no $\S 1^{\circ}$ Os cincos anos iniciais do Ensino Fundamental, excepcionalmente, poderão ser oferecidos em escolas nucleadas, com deslocamento intra campo dos alunos, cabendo aos sistemas estaduais e municipais estabelecer o tempo máximo dos alunos em deslocamento a partir de suas realidades, e no $\S 2^{\circ}$ Em nenhuma hipótese serão agrupadas em uma mesma turma crianças de Educação Infantil com crianças do Ensino Fundamental.
\end{abstract}

Nossa pesquisa busca saber como as atividades lúdicas estão sendo desenvolvidas nas escolas do campo, se de fato a coordenação pedagógica da escola na qual a pesquisa foi feita, está dando a real importância para o desenvolvimento dos alunos com atividades lúdicas, proporcionando-lhes uma aprendizagem prazerosa. Nesta perspectiva, é necessário entender que o lúdico poderá desenvolver nos alunos capacidades fundamentais para o seu desenvolvimento lógico e cognitivo, pois assim eles estarão trocando experiências de diversas formas e a aprendizagem se dará de forma mais significativa. Contudo, é preciso que o docente tenha conhecimento aprofundado a respeito, e clareza no que pretende fazer.

Para nos acercamos de conceitos-chaves na reflexão sobre a ludicidade na infância e sobre a ludicidade na infância campesina, bem como aprender outros estudos realizados neste campo, realizamos um levantamento, inicial, de pesquisas na área. A partir dos descritores "infância do campo"; "educação do campo e ludicidade"; "brincadeiras infantis e escola do campo", fizemos uma busca em sites, tais como SCIELO e GOOGLE SCHOLAR. Nossa busca nos forneceu 11 textos (10 artigos e 01 dissertação) que versaram sobre o tema de nossa pesquisa. Em seguida apresentamos um quadro-índice dos artigos encontrados e sistematizados por nós. 


\section{OUADRO 1 - LUDICIDADE, INFÂNCIA DO CAMPO E ESCOLA}

\begin{tabular}{|c|c|c|c|c|}
\hline TÍTULO & AUTOR(A) & $\begin{array}{l}\text { TIPO DE } \\
\text { PUBLI- } \\
\text { CAÇÃO }\end{array}$ & $\begin{array}{l}\text { ANO DE } \\
\text { PUBLI- } \\
\text { CAÇÃO }\end{array}$ & REFERÊNCIAS \\
\hline $\begin{array}{l}\text { Brincadeira em } \\
\text { Escola de Ensino } \\
\text { Fundamental: } \\
\text { Um estudo } \\
\text { observacional }\end{array}$ & $\begin{array}{l}\text { CORDAZZO, } \\
\text { Sheila Tatiana } \\
\text { Duarte, WES- } \\
\text { TPHAL, J. O., } \\
\text { TAGLIARI, F. B. } \\
\text { \& VIEIRA, M. L. }\end{array}$ & Artigo & 2010 & $\begin{array}{c}\text { Revista Interação em } \\
\text { Psicologia, 2010, 14(1), } \\
\text { p. 43-52/UFPR }\end{array}$ \\
\hline $\begin{array}{l}\text { Comportamentos } \\
\text { Lúdicos entre } \\
\text { Crianças do } \\
\text { Nordeste do Brasil: } \\
\text { Categorização de } \\
\text { Brincadeiras }\end{array}$ & $\begin{array}{l}\text { SANTOS, Ana } \\
\text { Karina \& DIAS, } \\
\text { A. M. }\end{array}$ & Artigo & 2010 & $\begin{array}{c}\text { Revista Psicologia: } \\
\text { Teoria e Pesquisa. } \\
\text { Out-Dez 2010, Vol. } 26 \\
\text { n. 4, pp 585-59/Instituto } \\
\text { de Psicologia da UNB }\end{array}$ \\
\hline $\begin{array}{c}\text { O Contexto das } \\
\text { Brincadeiras das } \\
\text { Crianças Ribeirinhas } \\
\text { da Ilha do Combu }\end{array}$ & $\begin{array}{c}\text { TEIXEIRA, } \\
\text { Sônia Regina } \\
\text { dos Santos \& } \\
\text { ALVES, J. M. }\end{array}$ & Artigo & 2008 & $\begin{array}{l}\text { Revista Psicologia: } \\
\text { Reflexão e Crítica, } \\
\text { 21(3), 374-382/Progra- } \\
\text { ma de Pós-graduação } \\
\text { em Psicologia } \\
\text { da UFRGS }\end{array}$ \\
\hline $\begin{array}{l}\text { Pivôs utilizados } \\
\text { nas brincadeiras de } \\
\text { faz-de-conta de } \\
\text { crianças brasileiras } \\
\text { de cinco grupos } \\
\text { culturais }\end{array}$ & $\begin{array}{l}\text { GOSSO, Yumi, } \\
\text { MORAIS, M. L. } \\
\text { S. \& OTTA, E. }\end{array}$ & Artigo & 2006 & $\begin{array}{c}\text { Revista Estudos de } \\
\text { Psicologia 2006, 11(1), } \\
\text { 17-24/Programa de } \\
\text { de Pós-graduação em } \\
\text { Psicologia da UFRN }\end{array}$ \\
\hline
\end{tabular}




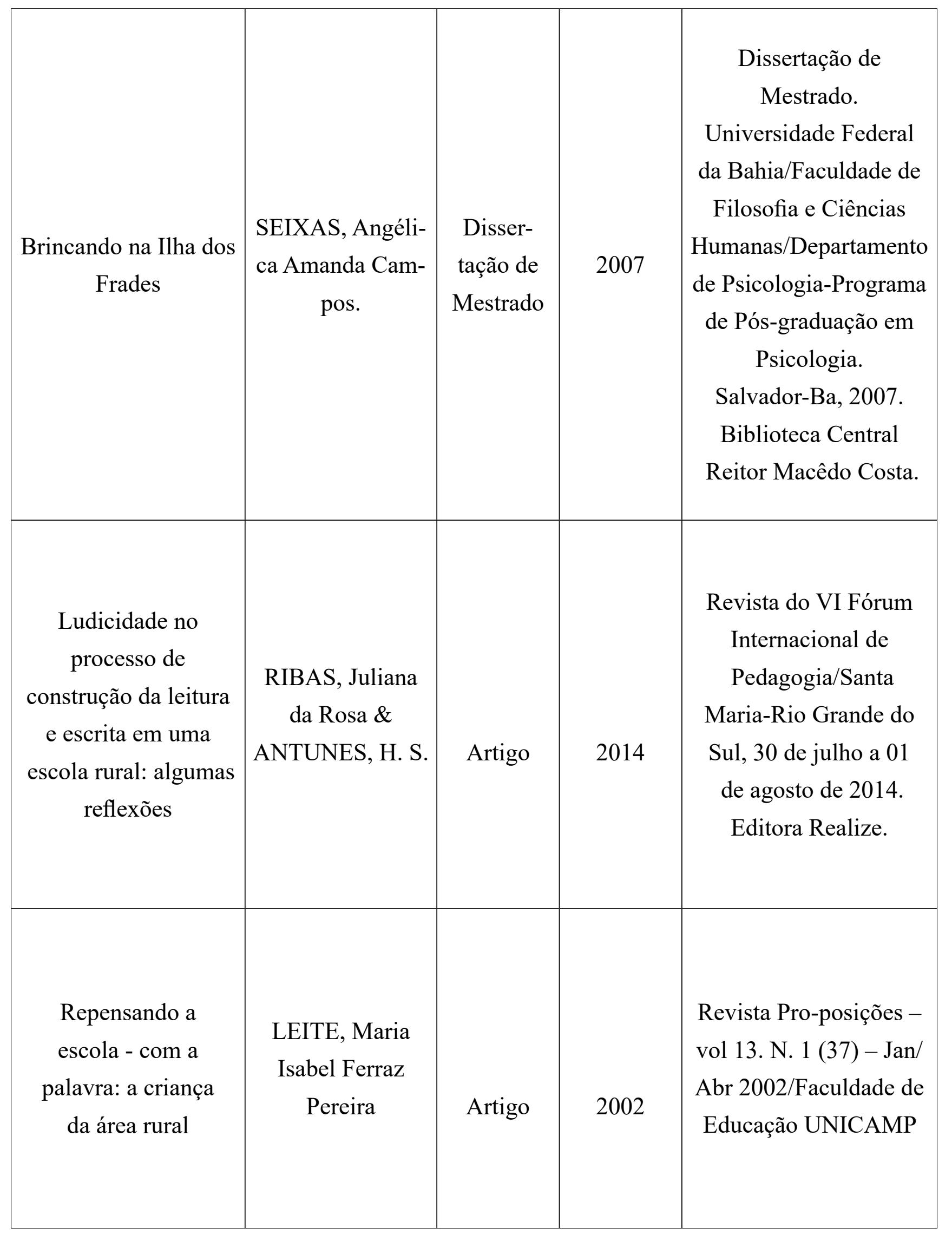




\section{LUDICIDADE, INFÂNCIA DO CAMPO E ESCOLA}

\begin{tabular}{|c|c|c|c|c|}
\hline TÍTULO & AUTOR(A) & $\begin{array}{l}\text { TIPO DE } \\
\text { PUBLI- } \\
\text { CAÇÃO }\end{array}$ & $\begin{array}{c}\text { ANO } \\
\text { DE PU- } \\
\text { BLICA- } \\
\text { ÇÃO }\end{array}$ & REFERÊNCIAS \\
\hline $\begin{array}{l}\text { Vivências de crianças } \\
\text { no ambiente rural: } \\
\text { aproximações e } \\
\text { distanciamentos na } \\
\text { educação infantil }\end{array}$ & $\begin{array}{l}\text { SILVA, Juliana } \\
\text { Bezzon da, } \\
\text { SILVA, A. P. }\end{array}$ & Artigo & 2013 & $\begin{array}{c}\text { Revista } \\
\text { Latino-americana } \\
\text { de Psicologia Volume } \\
45 \text { N. } 3 \text { p. } 351-362\end{array}$ \\
\hline $\begin{array}{c}\text { Educação e a infância } \\
\text { no campo: } \\
\text { um olhar sobre os } \\
\text { diferentes espaços } \\
\text { de aprendizagem }\end{array}$ & $\begin{array}{c}\text { DE COSTA, } \\
\text { Liciane \& PERI- } \\
\text { POLLI, O. J. }\end{array}$ & Artigo & 2012 & $\begin{array}{l}\text { Revista Eventos } \\
\text { Pedagógicos. V. 3, p } \\
\text { 159-169, Ago-Dez. } \\
\text { 2012/UNEMAT }\end{array}$ \\
\hline $\begin{array}{c}\text { Festas juninas nas } \\
\text { escolas: lições de } \\
\text { preconceitos }\end{array}$ & $\begin{array}{c}\text { CAMPOS, Judas } \\
\text { Tadeu. }\end{array}$ & Artigo & 2007 & $\begin{array}{c}\text { Revista Educação } \\
\text { Sociedade, Campinas, } \\
\text { vol 28, n. 99, p. 589- } \\
\text { 606, maio/ago. } 2007 . \\
\text { CEDES-UNICAMP }\end{array}$ \\
\hline $\begin{array}{l}\text { Crianças do campo - } \\
\text { os mudos da história? }\end{array}$ & $\begin{array}{l}\text { LEITE, Isabel } \\
\text { Ferraz Pereira }\end{array}$ & Artigo & 1996 & $\begin{array}{c}\text { Revista Estudos } \\
\text { Sociedade e Agricul- } \\
\text { tura, 6, julho 1996: } \\
\text { 170-191. UFRJ/ } \\
\text { ICHS/DDAS }\end{array}$ \\
\hline
\end{tabular}


Além das referências listadas anteriormente, recorremos a outros autores, tais como: Brougère, Gilles.(1998), Pires (2012), Vigostky (1988), Freire (1983)1 e Silva \& $\operatorname{Pasuch}(2010)^{2}$.

O objetivo de nossa pesquisa foi verificar qual a percepção das duas professoras do $2^{\circ}$ e $3^{\circ}$ anos da escola observada no município de Atalaia, sobre o lúdico como elemento importante no processo de ensino aprendizagem e como os professores dessa escola trabalham com o lúdico. Quais os recursos que os professores do campo têm para trabalhar, além do quadro de giz? E quais as práticas que são adotadas pelos educadores da escola do campo investigada, buscando saber se conhecem, se realmente sabem da importância do lúdico e como ele contribui para o desenvolvimento da criança. Espera-se, então, através de pesquisa bibliográfica e de campo, verificar como as práticas pedagógicas de ensino, com a utilização do lúdico, são desenvolvidas no âmbito da educação escolar na escola do campo investigada por nós.

Realizou-se, então, de forma complementar à pesquisa bibliográfica, uma breve pesquisa de campo, de caráter exploratório e qualitativa, tendo como instrumentos de coleta de dados observações não sistemáticas da atividade das crianças sujeitos da pesquisa, com vistas a identificar a vivência lúdica das mesmas no espaço de sala de aula. Fizemos uso ainda de um questionário semiestruturado, aplicado junto a professores da escola campo de pesquisa, buscando captar a percepção deles em torno da importância da ludicidade para o desenvolvimento das crianças.

\section{O LÚDICO}

A palavra "lúdico”, de acordo com o dicionário Michaelis·, está relacionada aos jogos e brinquedos. Se observarmos os educandos brincando, entenderemos como o lúdico é essencial para o seu desenvolvimento global, como traço universal da infância com

1 FREIRE, Paulo. Extensão ou comunicação? Rio de Janeiro, Paz e Terra, 1983. (Col. O mundo hoje, v. 24).

2 DA SILVA, Ana Paula Soares \& PASUCH, Jaqueline. Orientações Curriculares para a Educação Infantil do Campo (Versão preliminar). Extraído do site: file://D:/Downloads/oreint_curric\%20(1).pdf , acesso em 14 de agosto de 2015. 
uma visão de mundo mais real. Por meio de descobertas e da criatividade a criança se expressa, analisa, critica e transforma a realidade. Se esta educação lúdica se desenvolver de forma bem aplicada e compreendida ela contribuirá para a melhoria do ensino. Segundo Vygotsky (1984: p.97).

\begin{abstract}
A brincadeira cria para criança uma "zona de desenvolvimento proximal" que não é outra coisa se não a distância entre o nível atual de desenvolvimento, determinado pela capacidade de resolver independentemente um problema, e o nível atual de desenvolvimento potencial, determinado através da resolução de um problema sob a orientação de um adulto ou com a colaboração de um companheiro mais capaz.
\end{abstract}

Nesta perspectiva o brincar tem papel relevante, pois, brincando a criança desenvolve seu cognitivo, visual, auditivo, motor e tátil, é por meio das brincadeiras que a criança cria situações vivenciadas em seu cotidiano e estas são reelaboradas pela prática do faz- de- conta e a imaginação se desenvolve. Sendo assim, à medida que a criança aprende, através da brincadeira, ela dificilmente esquecerá esta aprendizagem, pois a mesma se deu de forma prazerosa. Portanto, a brincadeira deve ser parte integrante e de grande importância na proposta pedagógica das instituições de ensino.

Há, sobre a brincadeira, diversos olhares teórico-conceituais, muitas vezes conflitantes entre si. Em estudo realizado por SANTOS \& DIAS (2010) afirma-se a dificuldade de definir o que é brincadeira, mas os autores arriscam o esboço de uma definição. Vejamos:

Talvez o critério de maior concordância para definir a brincadeira é que esta parece não servir para nenhum propósito imediato (Bjorklund, 2002); neste sentido podemos afirmar que, na brincadeira, os meios justificam os fins, postulação amplamente aceita, sobretudo sob o enfoque etológico. É a partir desta falta de propósitos que ocorre na brincadeira o self-handicap, isto é, dinâmica lúdica através da qual os mais fortes ou mais experientes se colocam em desvantagem em relação aos mais fracos e mais jovens (Spinka, Newberry \& Bekoff, 2001)”. (p. 586)

Ainda que tenhamos que considerar que a maioria dos estudos que encontramos sobre o tema, façam a abordagem da brincadeira desde o papel que a mesma pode desempenhar no processo mais amplo de desenvolvimento da criança e como isso se reflete nas 
aprendizagens realizadas pelas crianças em sua escolarização, é importante considerar esse ponto de vista, uma vez que, em geral, nós educadores buscamos construir argumentos sólidos acerca da "funcionalidade" ou da "utilidade" da brincadeira, revestindo esta atividade infantil (e adulta) de uma aura escolarizada e didática. Somos quase sempre rápidos e enfáticos em buscar os "benefícios" do "uso" da brincadeira em ambiente escolar/de sala de aula para a promoção ou melhoria de aprendizagens diversas. SANTOS \& DIAS (2010) problematizam essa forma de conceber ou mesmo de "justificar" a presença da brincadeira em ambientes escolares.

Para entendermos essa importância da brincadeira para o desenvolvimento global da criança, precisamos pensar na criança, na cultura de pares onde as crianças produzem e se relacionam sem a intervenção de um adulto, na cultura infantil, na relação adulto-criança, nos espaços e materiais que se oferecem a ela e nos objetivos dessa educação. No contexto específico do campo, precisamos considerar que há, em geral, espaços amplos onde elas podem correr livremente; interagir com animais e com a natureza; muitos "saberes" são transmitidos ainda pela oralidade e, dessa forma, as gerações mais antigas vão transmitindo costumes, crenças, formas de socialização, entre as quais, formas de brincar. É necessário entender que o lúdico irá desenvolver nas crianças capacidades fundamentais para o seu desenvolvimento, pois assim ela estará criando situações e interagindo com o próximo, trocando experiências de diversas formas e assim a aprendizagem se dará de forma prazerosa. Segundo Vygotsky (1984 apud Rego 2012: p.2).

O lúdico permite um desenvolvimento global e uma visão de mundo mais real. Por meio das descobertas e da criatividade, a criança pode se expressar, analisar, criticar e transformar a realidade. Se bem aplicada e compreendida, a educação lúdica poderá contribuir para a melhoria do ensino, quer na qualificação ou formação crítica do educando, quer para redefinir valores e para melhorar o relacionamento das pessoas na sociedade.

Ainda que as novas tecnologias - que também chegaram ao campo - venham modificando esses costumes e formas de interação, para o desenvolvimento do nosso estudo, nos pareceu importante fazer um levantamento das brincadeiras e vivências da ludicidade entre os sujeitos de nossa pesquisa. 
Segundo Brougère (1998), é necessário que se busque colocar as formas lúdicas e educativas no mesmo espaço, mas com clareza sobre os atributos de cada uma. Sendo assim, o educador precisa de fato estar ciente da sua proposta pedagógica para o trabalho com o lúdico, como também entender o quanto suas ações irão influenciar na aprendizagem dos seus alunos. Existem várias formas de ver esta aprendizagem, muito já fala-se sobre ela, no entanto, é preciso entender que o lúdico é um dos instrumentos essenciais para o trabalho pedagógico escolar na educação. No entanto não basta disponibilizar brincadeiras e brinquedos, é preciso um planejamento do espaço físico e de ações intencionais que favoreçam um brincar de qualidade, com clareza do que se pretende alcançar com sua utilização. É importante dar espaço à invenção e à produção de novos significados, saberes e práticas, e se de fato estamos em busca de uma educação que abre espaços a seus educandos para que eles se tornem sujeitos com capacidades de reflexão e críticas perante a sociedade, o lúdico tem grande importância nesse processo de aprendizagem. Vygotsky (1988) afirma que:

O brincar é uma atividade humana criadora, na qual imaginação, fantasia e realidade interagem na produção de novas possibilidades de interpretação, de expressão e de ação pelas crianças, assim como de novas formas de construir relações sociais com outros sujeitos, crianças e adultos. (p.37).

Dessa forma, podemos compreender que as brincadeiras contribuem para o desenvolvimento cognitivo, sendo aquelas atividades realizadas no sentido de apropriação de conhecimentos e desenvolvimento físico e social. Alguns estudos que se baseiam em observação da atividade lúdica infantil, trazem informações que são ricas para essa compreensão em torno do lugar que a brincadeira ocupa na vida das crianças. Em estudo de CORDAZZO, WESTPHAL, TAGLIARI \& VIEIRA (2010) se evidencia que, a depender da idade das crianças ou mesmo do número de parceiros, as brincadeiras vão se modificando. Ao se referirem aos tipos de brincadeira (faz-de-conta, construtivas ou ao jogo de regras) os autores dão ênfase ao desenvolvimento da capacidade imaginativa; à aproximação de quem brinca ao universo do outro, a partir da "inversão de papéis"; ao desenvolvimento da linguagem; ao desenvolvimento de habilidades motoras; à estimu- 
lação dos sentidos e da criatividade; à negociação em torno de regras, o que propicia o exercício de interação social. Como elemento que se mantem constante, para além dessas mudanças, estaria o prazer envolvido no ato de brincar.

O reconhecimento de que há, no universo das brincadeiras infantis, elementos que podem variar, se modificar, a depender de determinadas características, se aproxima de um elemento que vem ganhando espaço nos estudos sobre a brincadeira e a ludicidade na infância. Trata-se do elemento contextual. O contexto em que a criança cresce, se desenvolve, é educada, com o qual ela interage, parece influenciar os tipos de brincadeira e os modos de brincar desenvolvidos pelas crianças. Em estudo de SANTOS \& DIAS (2010) já mencionado anteriormente, essa influência é evidenciada. Vejamos:

As crianças apresentam ou não certos tipos de brincadeira por causa das condições contextuais como o espaço físico e o tempo disponível para brincar e objetos para sustentar sua imaginação. As atitudes dos adultos em relação à brincadeira também são fator crítico. Se faltarem condições para a aprendizagem em um grupo sociocultural, essa deficiência vai se refletir na ausência de determinada brincadeira ou no seu subdesenvolvimento. Para Johnson, Christie e Yawkey (1999), fatores sociais e econômicos pesam mais que fatores culturais em contribuir para a frequência e a qualidade da brincadeira. Assim, o conteúdo da brincadeira seria diferente por causa da cultura, mas o nível da brincadeira dentro de cada cultura varia em função do nível socioeconômico. (p. 588)

A ênfase dada à importância do contexto como elemento que estrutura a brincadeira infantil também aparece em estudo de TEIXEIRA \& ALVES (2008):

As ações da criança nas brincadeiras são circunscritas, continuamente, tanto por elementos de sua cultura coletiva, quanto por elementos de sua cultura pessoal (Valsiner, 1997, 2000). Desse modo, ao brincar a criança imita os papéis sociais presentes nas atividades de seu grupo cultural, mas, ao mesmo tempo, os reinterpreta de acordo com os significados pessoais por ela atribuídos às suas ações. Tanto os significados coletivos quanto os significados pessoais vão sendo, continuamente, reconstruídos e redefinidos. Neste sentido, a compreensão dos textos criados pelas crianças em suas brincadeiras requer a elucidação do contexto cultural onde eles são produzidos. (p. 375)

Para o nosso estudo, em particular, a consideração do elemento contexto é fundamental, uma vez que um dos princípios basilares da Educação do Campo é o respeito ao contex to como ponto de partida, chão e horizonte para o processo educativo. Vinculado 
a esse princípio está também o do respeito à diversidade e especificidade dos contextos e sujeitos rurais. Em trabalho de GOSSO, MORAIS \& OTTA (2006) o contexto também aparece como elemento que carrega os brinquedos e brincadeiras de sentido, bem como situa a criança dentro de sua cultura. Se referindo a estudos de McLoyd (1983) e Smith (1995) ou de Sager e Sperb (1998), GOSSO, MORAIS \& OTTA (2006) afirmam que tais estudos constataram que, na interação com elementos naturais - bastante comuns em contextos rurais - ou mesmo com brinquedos menos estruturados (entendemos serem brinquedos menos "prontos" ou industrializados) as crianças tendem a desenvolver mais sua capacidade criativa, realizando transformações simbólicas mais ricas.

As brincadeiras no mundo rural, com suas práticas cotidianas, expressam histórias passadas de geração em geração. Então estas devem ser resgatadas e incorporadas à rotina escolar. Permitir que as crianças brinquem é uma tarefa essencial do ato de educar. Portanto, permitir que o educador tenha em seu currículo um conhecimento que aborde a importância do lúdico na formação dos seus educandos é de suma importância, para que os educandos possam desenvolver atividades específicas voltadas para o seu desenvolvimento cognitivo, social, linguístico e cultural de forma prazerosa.

Nesta perspectiva, para propormos o lúdico como recurso pedagógico, é necessário que estejamos preparados para as escolhas das propostas pedagógicas nestas atividades, salientando que fica sob a responsabilidade do professor a intervenção diante das necessidades que surgirem. Esse processo precisa ser posto em curso, considerando as especificidades da infância campesina. Em seguida trataremos de alguns elementos inerentes aos modos de ser criança nos campos brasileiros.

\section{- LUGar do lÚdico NA INFÂNCIA DO CAMPO: ALGUNS APONTAMENTOS}

Embora os dados estatísticos oficiais anunciem a universalização da educação escolar em quase todo o território nacional, a persistência da desigualdade entre as áreas rurais e urbanas são bem evidentes. Milhares de crianças e jovens enfrentam inúmeras 
barreiras para ter acesso a uma educação de qualidade. A ausência de políticas específicas para as escolas do campo é uma das principais causas para que ocorra essa desigualdade.

O direito à educação básica do campo vem sendo negligenciado ao longo de muitos anos. Muito já se produziu no sentido de indicar, historicamente, como essa negligência foi sendo materializada, seja no que diz respeito à ausência ou descontinuidade de políticas educacionais e sociais mais consistentes para a população campesina, seja no que se refere ao que podemos chamar de processos pedagógicos que envolvem desde concepções e práticas docentes até materiais didáticos ou "modelos" de organização da escola no/do campo, quase sempre partindo do pressuposto de que as escolas rurais deveriam ser cópias - no mais das vezes, mal feitas - do "modelo" de ensino urbano. Em documento recente produzido pelo Conselho de Desenvolvimento Econômico e Social/ CDES, o tema da desigualdade campo-cidade, em especial no que se refere ao acesso à escolarização, é retomado.

As escolas do campo são as que estão em piores condições de infraestrutura para receber estudantes - pelo Censo Escolar de 2010, quase 15\% não possuem sequer energia elétrica. Cerca de $90 \%$ das escolas não possuem biblioteca e $80 \%$ delas não dispõem de laboratório de informática. Menos de $1 \%$ dos estabelecimentos de ensino no campo estão equipados com laboratórios de ciências. E é importante lembrar que a pequena melhoria recente nesses indicadores, que permanecem muito graves, também é consequência do forte - e controverso processo de nucleação e fechamento de escolas rurais, que fechou 41 mil escolas rurais na última década ${ }^{3}$.

Em muitos aspectos essa desigualdade, ainda que havendo sofrido redução nos últimos 12 anos, ainda persiste. Se considerarmos, por exemplo, os dados da PNAD/ IBGE ao trazer dados comparados dos anos 2001 a 2012 referentes às medias de anos de estudo da população de 15 anos ou mais no Brasil, essa média evoluiu nas zonas urbanas, de 6,9 anos em 2001 para 8,4 anos em 2012, enquanto nas zonas rurais brasileiras os índices observados nos mesmos anos de referência foram de 3,4 e 6,1 anos de estudos

3 As desigualdades na escolarização no Brasil: relatório de observação $n^{\circ}$ 5. Brasília: Presidência da República, Conselho de Desenvolvimento Econômico e Social - CDES, 2014. (p. 25). Encontrado no link: http://www.cdes.gov.br/observatoriodaequidade/acervo_virtual.php?pg=2., acesso em 20/07/2015. 
em média, respectivamente. Ou seja, os sujeitos do campo na faixa etária em questão, lograram alcançar, em 2012, uma média de anos de estudos ainda abaixo da observada nas zonas urbanas em 2001. O fato exige de nós que compreendamos o forte abismo que ainda separa as realidades urbanas e rurais, especialmente no que diz respeito ao acesso a DIREITOS sociais básicos, tais como a Educação/escolarização.

O alerta para a necessidade, urgente, de maior atenção à garantia de acesso à escolarização para a população campesina, entendendo o mesmo como um DIREITO, vem sendo insistentemente dado pelos movimentos sociais e por coletivos de educadores e educadoras do campo. Em alguns documentos oficiais, tais como a Resolução nº 1 , de abril de 2002, da Câmara de Educação Básica/Conselho Nacional de Educação, que estabelece as Diretrizes Operacionais para a Educação Básica nas Escolas do Campo, isso é evidenciado. A referida Resolução, em seu Art. $5^{\circ}$ afirma que as propostas pedagógicas das escolas do campo, respeitadas as diferenças e o direito à igualdade e cumprindo imediata e plenamente o estabelecido nos artigos 23, 26 e 28 da LDB 9.394/96, devem incorporar a diversidade do campo em todos os seus aspectos: sociais, culturais, políticos, econômicos, de gênero, geração e etnia.

Os povos do campo têm uma raiz histórica própria, um jeito de viver e de trabalhar diferente do mundo urbano, e que inclui distintas maneiras de ver e se relacionar com o tempo, o espaço, o meio ambiente e de organizar a família, a comunidade, o trabalho e a educação (ARROYO, CALDART e MOLINA, 2004). (PIRES, 2012, p.43).

PIRES, (2012) reforça em seus estudos, ao constatar “essas desigualdades”, inclusive as educativas e escolares, que há uma dívida histórica por parte dos poderes públicos quanto ao aporte de políticas para os povos do campo. [...] (PIRES, 2012: p. 24). A educação do campo deveria ser específica e diferenciada, estando pautada na realidade daquelas comunidades, respeitando suas especificidades, garantindo assim que todas as pessoas tenham acesso a uma educação de qualidade, voltada aos interesses da vida do campo. É necessário reconhecer os direitos das escolas do campo e para o campo, para valorização da vida dos campesinos, pois esta escola tem um papel muito importante nesse processo, que é de oferecer alternativas de aprendizagem que valorizem a cultura 
local. Ou seja, é necessário que exista um currículo contextualizado que dialogue com o cotidiano de cada localidade. Segundo CALDART, (2004, p.5).

O currículo nessa perspectiva de educação contextualizada será um instrumento que considera a realidade socioambiental, política, cultural e diversa do Semiárido - espaço repleto de complexas relações, permeado por exclusões e lutas, que ressignifique a própria prática educativa, por que promove a participação do professor e da professora, dos/as educandos/as, e da comunidade, na sua construção e na sua realização. Um currículo que contemple uma educação vinculada, política e pedagogicamente, com a história, a cultura e as causas sociais e humanas dos sujeitos do campo, e não apenas um apêndice da escola pensada na cidade e localizada "no" campo.

Nesta perspectiva, se faz necessário que os órgãos governamentais, através da efetivação de políticas públicas e ações que possam resolver esta dívida histórica com as populações rurais, assegurem, de fato, os direitos dos povos do campo, e assim garanta uma educação de qualidade.

Reconhecendo esses elementos de fundo e tomando-os como elementos norteadores do nosso estudo, podemos afirmar que as crianças do campo, como qualquer criança, brincam de correr, de faz-de-conta e inventam muitas histórias, sendo o campo o palco das suas brincadeiras na (re) construção de situações do cotidiano do campo e nas relações com as atividades dos pais/familiares cheios de histórias divertidas e criativas. Uma referência importante que encontramos para ajudar na identificação dessa especificidade das crianças do campo foi o documento das Orientações Curriculares para a Educação Infantil do Campo (SILVA \& PASUCH: 2010) ${ }^{4}$. Não tivemos a Educação Infantil como foco em nosso estudo, mas o documento em questão é esclarecedor na identificação de alguns traços característicos da Infância do Campo e do lugar do lúdico na vida das crian-

4 SILVA, Ana Paula Soares da Silva \& PASUCH, Jaqueline. Orientações curriculares para a Educação Infantil do Campo. Texto elaborado no contexto do Grupo de Trabalho "Orientações Curriculares para a Educação Infantil do Campo", composto, além das duas autoras, por: integrantes do MST (Edna Rossetto, Márcia Ramos, Isabela Camini); CONTAG (Eliene Novaes Rocha, Tânia Dornellas); FETAG-RS (Sonilda Pereira); Universidades (Anamaria Santana - UFMS, Antônia Fernanda Jalles UFRN, Eliete Avila Wolf - UnB, Fernanda Leal - UFCG, Isabel de Oliveira e Silva - UFMG, Maria Natalina Mendes Freitas - UFPA, Sônia Regina dos Santos Teixeira - UFPA). Versão Preliminar, 04 de novembro de 2010. Extraído do sitio web: http://portal.mec.gov.br/index.php?Itemid=\&gid=6675\&option=com_docman\&task=doc_download, acesso em 14/07/2015. 
ças campesinas. Gostaríamos de apresentar uma reflexão inicial das autoras:

[...] é importante considerar que as crianças do campo possuem seus próprios encantos, modos de ser, de brincar e de se relacionar. As crianças do campo têm rotinas, experiências estéticas e éticas, ambientais, políticas, sensoriais, afetivas e sociais próprias. Os tempos de plantar e de colher, os ciclos de produção, de vida e de morte, o tempo das águas e estiagem, as aves e bichos do mato, dos mangues, dos pantanais, a época de reprodução dos peixes, aves, pássaros e outros animais, o amanhecer e o entardecer, o tempo de se relacionar com os adultos e crianças, tudo isso marca possibilidades diferenciadas de viver a infância, na multiplicidade que o campo brasileiro se configura, numa relação orgânica com a terra que pinta os pés com força e marca a pele, os dedos e as unhas e delineia sorrisos. (p. 01)

Para nós o conjunto de descrições que as autoras fazem sobre a criança do campo e sobre o campo, em sua diversidade, recupera algo que é precioso para a Educação do Campo. A perspectiva de olhar para o campo e seus sujeitos a partir de suas potencialidades, rompendo com o costumeiro olhar que enxerga apenas miséria, carência, ignorância. Em suma, o olhar que define o campo como o lugar da falta. As autoras tomam outra perspectiva, que é a que interessa para a discussão que fazemos aqui. Cuidadosa e detalhadamente, descrevem infinitas possibilidades de brincadeiras e brinquedos criados, construídos pelas crianças do campo, quase sempre a partir da riqueza e diversidade de materiais que estão em seu entorno, que compõem o cenário do seu cotidiano. Vejamos:

[...] São principalmente cenários que estruturam, dão vida e sentido às experiências das crianças na exploração corporal, ética, estética e política do mundo; na criação de brinquedos e brincadeiras, enredos e narrativas. Compõem, nas interações e relações entre crianças e adultos e entre as próprias crianças, os processos de construção de sentidos sobre si mesmas, sobre o mundo e suas comunidades. Constituem-se como espaços de aprendizagens complexos, um verdadeiro laboratório da própria vida; um laboratório em que se encontram os saberes cotidianos da criança enriquecidos pela sistematização, observação minuciosa e cuidadosa, pela mediação do professor. (SILVA \& PASUCH: 2010, p. 12)

Alguns estudos sobre a infância no campo e a ludicidade afirmam haver algumas diferenças entre as formas de brincar de crianças urbanas e rurais. Mais de um estudo, entre os que encontramos em nossa pesquisa, afirmaram que, em geral, o fato das crianças do campo estabelecerem em seu cotidiano uma proximidade maior com o universo de trabalho dos seus pais, de sua família, acaba determinando que o conteúdo de suas 
brincadeiras de faz-de-conta esteja bastante influenciado por esse universo. No estudo de SANTOS \& DIAS (2010) isso é evidenciado.

Têm-se constatado em crianças urbanas uma maior presença de conteúdos fantasiosos nas brincadeiras simbólicas, o que Smith (1982) relaciona com o fato de o trabalho dos adultos estar distanciado das crianças pequenas, levando-as a buscar outras fontes de inspiração para a interpretação de papéis sociais, o que é encontrado facilmente em filmes e programas de televisão. Este foi um fato ressaltado nos dados de pesquisas brasileiras em contextos não-urbanos (Gosso \& Otta, 2003; Moraes \& Otta, 2003). Nesses contextos foi pouco encontrada a influência de conteúdos extraídos da televisão e mais episódios onde a fantasia estava ligada à realidade de seu contexto. No estudo com índios Xocó, Bichara (1999) também verifica a existência da mesma relação, encontrando mais temas relacionados com o cotidiano e com um modo de vida rural e ribeirinho. (p. 592)

Em estudo de TEIXEIRA \& ALVES (2008) este também é um elemento destacado, ao identificarem que, nas brincadeiras de faz-de-contas de crianças ribeirinhas, elas reproduziam as ocupações dos adultos, seja na coleta de açaí ou vendendo o que foi colhido. A partir da síntese que faziam em torno destas ocupações, através da observação do cotidiano de trabalho dos adultos, iam reelaborando esse cotidiano em suas brincadeiras. Neste mesmo estudo os autores puderam observar o rico processo de aprendizagem das crianças menores com as maiores, numa relação - na brincadeira - na qual as mais velhas iam estruturando o faz-de-conta, organizando os papeis que cada um deve desempenhar ou delineando as relações entre os "personagens".

Alguns autores, tais como LEITE (2002), chamam atenção para o fato do trabalho ser uma dimensão e um elemento que transversaliza as relações no campo; as relações na família campesina e que envolve também a criança. Em estudo realizado pela autora, esse papel estruturante que o trabalho desempenha nos modos de viver dos camponeses é evidenciado. Ela observou, por exemplo, que na realidade do assentamento rural onde desenvolveu sua pesquisa, havia uma forte relação entre brincar-trabalhar-aprender. Buscando apoio em Martins (1191) a autora recupera a ideia de que, nesse contexto específico, seja através da transmissão oral ou do "aprendizado por modelo", os sujeitos campesinos compreendem esse aprendizado como "missão familiar", a partir do qual 
são preservadas a própria família, sua cultura e comunidade. Não é nosso objetivo fazer essa discussão, mas consideramos importante acrescentar que não ignoramos que muitas crianças no Brasil - a despeito de todos os avanços legais e as conquistas feitas desde a aprovação do Estatuto da Criança e do Adolescente e da implementação de algumas políticas de defesa e preservação dos direitos da criança e do adolescente - ainda sofrem em frentes de trabalho que impedem e prejudicam o seu pleno desenvolvimento e isso também ocorre nos contextos rurais. No entanto, a título apenas de breve esclarecimento, acreditamos que há um equívoco quando se toma como iguais o trabalho desenvolvido por crianças e adolescentes em suas propriedades e no modelo da agricultura camponesa familiar e o trabalho que eles possam desenvolver em propriedade alheia, sob um regime de exploração. Também ao estudar as vivências de crianças em um assentamento de reforma agrária SILVA \& SILVA (2013) reconhecem a importância do trabalho e sua relação com as brincadeiras infantis.

Para grande parte das crianças, as possibilidades retratadas pelas vivências descritas relacionam-se a um imaginário e a uma prática em que se cruzam brincadeira, relações com a terra, rios, plantas e animais, numa composição que privilegia a liberdade, a criação e a construção da autonomia. O espaço é significado na sua dimensão promotora de interações diferenciadas com a natureza e o cultivo da terra. Nesse ambiente, os participantes compreendem que a criança vive intensamente a brincadeira, sendo o local de recreação expandido para todo o assentamento. (p. 356)

As pesquisas às quais tivemos acesso e usamos aqui como referência indicam essa relação entre o cotidiano das famílias do campo e as atividades lúdicas das crianças enquanto um traço característico dos contextos rurais e isso acaba por materializar-se em um desafio a educadores e educadoras e às escolas do campo. Vejamos o que dizem, por exemplo, COSTA \& PERIPOLLI (2012):

O aluno campesino vive um processo contínuo de aprendizagens, seja no ambiente escolar, seja na lavoura, no cuidado com os animais ou brincando. Todos os espaços transformam-se em aprendizagens, aprendem a ler e escrever, a varrer a casa e tratar dos animais, a plantar e a colher, se divertem pescando, correndo, subindo em árvores, entre outras atividades. Adquirem responsabilidades, valores e comportamentos, estando em constante desenvolvimento. Também in- 
fluenciam na história, na cultura e nas políticas educacionais, fazendo com que sejam adequadas ao universo em que vive. A educação da infância do campo possui especificidades diferentes das crianças urbanas. A todo instante elas tem a oportunidade de brincar, de fazer atividades escolares e de realizar pequenos trabalhos, está sempre em movimento o campo lhes oferece isso, momentos de constante aprendizagem". (p. 161)

Uma vez tendo esclarecido alguns pontos em torno a infância do campo e suas vivências lúdicas, podemos avançar no sentido de nos aproximarmos do contexto de nossa pesquisa de campo, para buscar construir algum diálogo entre a realidade pesquisada por nós e o nosso referencial.

A proposta desta pesquisa, "O lúdico como Elemento Motivador na Educação das Crianças do Campo no município de Atalaia-Al”, tem como finalidade estudar as possibilidades do ensino das crianças do campo de forma lúdica e também de conhecer as práticas da ludicidade adotadas pelos docentes no desenvolvimento desses educandos e qual a importância que os professores dão às atividades lúdicas trabalhadas no ensino aprendizagem. Segundo Rubem Alves (1987):

O lúdico se baseia na atualidade, ocupa-se do aqui e do agora, não prepara para o futuro inexistente. Sendo o hoje a semente de qual germinará o amanhã, podemos dizer que o lúdico favorece a utopia, a construção do futuro a partir do presente.

Sendo assim nosso objetivo foi investigar o lúdico como categoria central importante na aprendizagem das crianças do ensino fundamental I do Campo em uma escola situada no povoado de Olhos D'água no município de Atalaia - AL, tendo o mesmo como elemento motivador para a realização dessa aprendizagem. Buscamos também analisar as relações do ensino lúdico no cotidiano escolar rural; estudar quais influências as atividades lúdicas trazem na formação dos alunos do campo; identificar quais são as práticas de brincadeiras espontâneas das crianças do campo; quais são as práticas de brincadeiras e inserção do lúdico desenvolvidas em sala de aula ou pela escola e que desafios e conquistas os professores identificam nesse processo. 


\section{RESULTADOS E DISCUSSÃo}

O Município de Atalaia, no qual está localizada a Escola pesquisada, tem fortes características rurais. De acordo com dados do $\mathrm{IBGE}^{5}$, no ano de 2014, a população de Atalaia estava em torno de 47 mil habitantes. Desse total, o município contava, no mesmo ano, com cerca de 22 mil pessoas vivendo na zona rural. Na economia, o município se destaca na produção de banana; laranja; manga e pimenta do reino, dentre as lavouras permanentes, e no cultivo da batata doce; feijão; mandioca e milho, dentre as lavouras temporárias. Destaque-se ainda a lavoura da cana de açúcar. O município ainda tem como característica de sua economia, a criação de bovinos; equinos; caprinos, ovinos; suínos e galináceos, além da produção de leite de vaca. Marcas da cultura local, pode-se destacar ainda a devoção à Nossa Senhora das Brotas, padroeira da cidade, bem como as Cavalhadas e Vaquejadas, que costumam animar a população.

Para entender melhor o contexto no qual nossa pesquisa foi feita, é importante também esclarecer, por exemplo, que das 52 escolas existentes no município de Atalaia, 31 são rurais e 21 são escolas urbanas. Do total de escolas do município, de acordo com dados do INEP ${ }^{6}$, haviam em 2014, 14 escolas paralisadas. Destas, 11 eram escolas rurais. Esse é um dado importante, que pode sinalizar o processo ao qual já fizemos referência, de redução da oferta de escolarização para a população campesina, em sua própria localidade, apesar desta oferta figurar como um direito na Matriz Legal que fundamenta a Educação do Campo.

A escola na qual desenvolvemos nossa pesquisa atende em média 170 alunos nos turnos matutino e vespertino, sendo que no $2^{\circ}$ ano matutino encontram-se matriculados 20 alunos e no $3^{\circ}$ ano matutino 25 alunos, estas foram as duas turmas observadas por nós. A escola oferta á comunidade: educação infantil com primeiro e segundo período e ensino fundamental 1 . O corpo docente de professores da escola é composto por 07

5 Extraído do site do IBGE, http://www.cidades.ibge.gov.br/, em 20/07/2015.

6 Extraído do site do INEP http://www.dataescolabrasil.inep.gov.br/dataEscolaBrasil/home.seam , em 10/08/2015. Dados finais do Censo Escolar 2014, publicados no Diário Oficial da União no dia 09 de janeiro de 2015 . 
professoras todas com formação em pedagogia, sendo duas pós graduadas em psicopedagogia. Escolhemos fazer nossa pesquisa na referida escola por se tratar de um espaço no qual uma de nós já lecionou, e, durante essa experiência, não foi possível identificar, de maneira clara, o lugar ocupado pela ludicidade nas práticas educativas desenvolvidas na escola.

As condições físicas de conservação da sala de aula eram adequadas, sendo uma sala ampla, com uma janela, um ventilador que proporcionam uma boa ventilação, a mesma também tem uma boa iluminação artificial e natural, no entanto não identificamos nenhum material lúdico nestas salas disponíveis para os alunos. Não existem materiais pedagógicos diversificados Como: jogos, livros paradidáticos para contação de histórias, as aulas se limitam apenas ao livro didático e ao quadro e giz. Negligenciando mais uma vez o desenvolvimento e aprendizagem dos alunos, uma que sabemos a brincadeira precisa estar presente nas salas de aulas, não apenas como algo para passar o tempo, mas como recurso pedagógico que auxiliará na aprendizagem dos alunos. Segundo Carlos Drummond de Andrade: “Brincar não é perder tempo, é ganhá-lo. É triste ter meninos sem escola, mas mais triste é vê-los enfileirados em salas sem ar, com exercícios estéreis, sem valor para a formação humana".

A partir das observações feitas sobre as atividades lúdicas das crianças nas salas do $2^{\circ}$ e $3^{\circ}$ anos do Ensino Fundamental I, do município de Atalaia, a única escola do campo existente nessa comunidade, e a partir das entrevistas realizadas com as professoras: Prof. Margarida e Prof. Rosa, com questionários semiestruturados, obtivemos algumas informações complementares para o nosso estudo.

Foi realizada, então, uma pesquisa de natureza qualitativa, cujo método de procedimento se aproximou do Estudo de Caso, Esses dados nos deram suporte para o entendimento sobre como é vivida a ludicidade na sala de aula. Consequentemente, a partir desses dados, nos foi possível conhecer um pouco mais sobre como se dá essa prática pedagógica na escola que investigamos, no município de Atalaia - Al. Utilizamos como ferramenta de coleta de dados a observação livre, na qual, segundo Triviños (1987) o pesquisador precisa considerar que: 
Observar, naturalmente, não é simplesmente olhar, observar é destacar de um conjunto (objetos, pessoas, animais etc.) algo especificamente, prestando, por exemplo, atenção em suas características (cor, tamanho etc.). (Triviños, 1987, p.153).

Fizemos uso também da entrevista semiestruturada. Realizamos a entrevista com a professora Margarida, do $2^{\circ}$ ano e a professora Rosa, ${ }^{7}$ do $3^{\circ}$ ano do ensino fundamental da escola campo de pesquisa, e a partir disto, buscamos o entendimento através dos relatos coletados com esses profissionais com relação as suas propostas pedagógicas direcionadas a aprendizagem dos seus alunos com a utilização de atividades lúdicas.

Quando perguntamos a professora Margarida do $2^{\circ}$ ano, de que forma o lúdico faz parte das suas aulas e qual a importância do lúdico para aprendizagem do aluno, ela nos relatou que:

Sei que é importante, que a criança aprenda brincando, mas, poucas vezes consigo fazer esse elo entre a brincadeira e o conteúdo, é muito raro, pois dou prioridade aos conteúdos que me são cobrados durante o ano letivo.

A professora Rosa do $3^{\circ}$ ano quando abordada com a mesma pergunta nos relatou que:

Trabalho mais os conteúdos que me são postos, se inventar essa história de brincadeira eles não querem nem copiar os assuntos do quadro, mas se tivesse tempo e materiais disponíveis para uma aula mais dinâmica eu poderia até fazer porque sei que o lúdico é importante, porém não tenho recurso para isso.

As falas das professoras se aproximam muito do que alguns estudos que acessamos encontraram como resultado, em especial o estudo realizado por LEITE (1996), no qual ela afirma que:

O lúdico está completamente ausente da instituição escolar. Está ausente da relação professor-aluno, da possibilidade de brincar, de dançar, pintar, passear, mexer-se. A meu ver, a escola deveria compreender a importância do lúdico na formação não apenas da criança mas também do educador. A ludicidade e a expressão artística são ainda comumente vistas como subversivas, e talvez por isso a escola se coloque como lugar que impede o lúdico[...]. (p. 185)

$7 \quad$ Nomes de flores, e fictícios, para preservar a identidade das professoras que colaboraram com a nossa pesquisa. 
A autora reflete, no entanto, que é fundamental que nos perguntemos se também a professora ou professor em questão tem tido espaço pra ser sujeito do seu processo de trabalho. E se pergunta a respeito de quais tem sido as condições de trabalho dos professores e professoras das escolas de educação básica. E nos atrevemos a perguntar quais tem sido as condições de trabalho das professoras e professores de escolas do campo.

\section{Observação das crianças}

Nossas observações foram realizadas com as crianças da Escola escolhida para nossa pesquisa, com as turmas do $2^{\circ}$ e $3^{\circ}$ anos do Ensino Fundamental I. Acompanhamos sua rotina escolar por um período de dois dias, desde o horário de chegada até o término da sua rotina escolar. Tivemos também acesso ao planejamento semanal das professoras, e constatamos que no mesmo havia o nome da matéria do dia e o conteúdo referente àquela aula, ressaltando que em cada dia se trabalha duas matérias, sendo uma no primeiro momento antes do intervalo e outra no segundo momento após o intervalo. Durante o processo de observação anotamos o que se passava dentro e fora da sala de aula com as referidas crianças como descreveremos posteriormente.

\section{Observação referente ao dia 01/12/2014 na turma do $3^{\circ}$ ano}

Ao chegarmos à escola ficamos em reunião com a professora e logo após às 7h30min fomos para sala, e os alunos estavam brincando livremente sem intervenção de um adulto. Eles estavam bem socializados, com exceção de uma menina (R.A) que só observava outras crianças brincarem. Ela ficava o tempo todo sentada com as mãos no queixo, sem fazer nada.

A professora entra na sala e cumprimenta as crianças, nos apresenta para elas e começa sua aula com indagações sobre aquele dia, o mês em que se encontram e o dia da semana. Sendo esse dia uma segunda feira, a professora pede que os alunos falem um pouco do seu final de semana. Em seguida a professora pede para que os alunos peguem seus livros didáticos e abram na página 62, que tem um texto chamado "Canção Amiga", e faz a leitura do texto "fatiado" por todos os alunos. Posteriormente a professora realiza a leitura, explicando e fazendo entendimento e interpretação do texto. Em seguida a pro- 
fessora pede que os alunos peguem o caderno para fazer um ditado de algumas palavras contidas no texto, depois, a professora realizou a correção do ditado pelos alunos no quadro.

Durante todo esse momento constatamos que alguns alunos ficam inquietos, enquanto um colega lê o outro não presta atenção, a professora chama a atenção do aluno e pede para continuar.

As $09 \mathrm{~h} 30 \mathrm{~min}$ tocou o intervalo e os alunos foram merendar e brincar à vontade até as 10:00 horas, ao retornarem para sala, a aula foi retomada com a matéria de matemática, com o conteúdo de multiplicação, que, segundo a professora, seria uma aula de revisão por já estarem concluindo o ano letivo. Essa aula foi realizada com atividades de situações problemas envolvendo a multiplicação, havendo a participação de todos e a interação com a professora. Às 11:00 horas os alunos foram liberados.

Nesta observação constatamos que o lúdico não foi contemplado em sala de aula, para o ensino aprendizagem dos alunos. A professora não utilizou nenhum recurso lúdico para realização das tarefas que foram desenvolvidas na sala de aula. Infelizmente só constatamos a presença de ludicidade nas brincadeiras realizadas no horário do intervalo e essas não tiveram nenhuma participação, acompanhamento ou intervenção da professora.

\section{Observação referente ao dia $08 / 12 / 2014$ na turma do $2^{\circ}$ ano}

Ao chegarmos na sala as 7:00 horas a professora estava recebendo os alunos e nós fomos receber as crianças com ela. Logo após, a professora começou a aula com uma música que todos os alunos participaram e interagiram, e fez uma introdução de deveres e obrigações dos alunos. Fez uma leitura do texto "O significado do Natal" e os alunos foram dizendo, com suas palavras, o que achavam do Natal. A maioria disse gostar do Natal, porque é bom, por conta do Papai Noel e também porque ganham presentes.

A professora copiou no quadro o texto "O significado do Natal", junto com perguntas interpretativas sobre o mesmo e, estipulou um tempo para que os alunos copiassem no caderno os escritos do quadro. Ao término das cópias de todos os alunos, a professora 
refez a leitura e, junto com os eles, foi respondendo, também no quadro, as respostas referentes ao texto. A professora corrigiu os cadernos dos alunos chamando um a um no birô. Quando faltavam dois alunos para terminar a correção, ocorreu o toque para o intervalo, às 09h30min horas. No retorno para sala de aula, onde a professora intitulou de segundo momento, a aula foi da matéria de ciências com o conteúdo "Seres Vivos", tratando-se de uma revisão.

Os alunos foram interagindo com a professora á medida que a mesma relembrava os tipos de seres vivos e ia copiando no quadro para que os alunos transcrevessem para o caderno. Em seguida a professora perguntou quem gostaria de falar sobre algum animal de estimação que teria em casa. E assim ocorreu que três alunos contaram histórias de seus animais de estimação. Logo em seguida ela explicou a importância de se cuidar bem desses animais e do quanto eles precisam de seus donos.

E então chegou o término da aula com o toque de largada e a professora se despediu dos alunos, e todos foram embora.

De acordo com o que pudemos observar, apenas nos intervalos das aulas as crianças envolvidas em nossa pesquisa puderam brincar. A observação que fizemos nos permitiu identificar alguns tipos de brincadeiras entre as crianças. Usamos a tipologia apresentada em estudo de SEIXAS (2007). A partir desse referencial, foi elaborado um instrumento de registro das nossas observações, por tipo de brincadeira realizada pelo grupo de crianças que observamos. Essa referência nos possibilitou identificar o seguinte:

Na Brincadeira Solitária': a criança brinca sozinha. Observamos a confecção de pulseiras com elásticos coloridos. Neste tipo de brincadeira não foi envolvida música e sua duração foi de 15 min, ocorrendo no espaço da sala de aula no horário do intervalo.

Brincadeira Associativa: duas ou mais crianças brincam juntas, uma mesma brincadeira, havendo interação entre elas, mas sem cooperação ou divisão de tarefas. Foi observada a brincadeira de pega - pega, não tendo musicalização, com duração de 10 min,

8 Extraído, com adaptação, do sítio web: http://www.pospsi.ufba.br/Amanda_Seixas.pdf. Acesso em 23/11/2014. 
ocorrendo no espaço livre da Escola.

Brincadeira Cooperativa: duas ou mais crianças brincam juntas, uma mesma brincadeira, havendo cooperação, ou divisão de tarefas, ou competição entre elas. Foi observado um jogo de futebol que não teve música, com duração de $20 \mathrm{~min}$, ocorrendo no espaço livre da Escola, todas as brincadeiras observadas não tiveram nenhuma articulação com atividades escolares ou ensino aprendizagem.

Constatamos também que não existe a participação e intervenção das professoras nos jogos ou brincadeiras realizadas pelas crianças, pois as professoras não ficam observando ou auxiliando os alunos durante a realização dessas brincadeiras.

Quanto ao tipo ou categoria de Brincadeira ou Jogo, verificamos o seguinte:

Tipo/Categoria de Brincadeira ou Jogo, Brincadeiras simbólicas ou imaginativas/ Faz-de-conta: a criança trata os objetos como se fossem outros, podendo atribuir propriedades diferentes das que possuem, ou atribuir a si e aos outros, papeis diferentes dos habituais e/ou criar cenas imaginárias e as representar. Na brincadeira que observamos denominada pelas alunas de brincadeira de mãe e filha, uma criança representa o papel da mãe e a outra o papel da filha, esta brincadeira teve duração de 20 min, e foi realizada dentro da sala de aula no horário do intervalo, não houve articulação com as atividades escolares ou ensino aprendizagem.

Brincadeiras turbulentas: envolvem comportamentos de luta, perseguição e fuga, sendo o riso um dos principais aspectos que distinguem de uma luta real. Esta brincadeira as crianças chamam de polícia, ladrão, com duração de 20 min, a mesma foi realizada no espaço livre da Escola e nesta brincadeira não houve constatação de articulação com as atividades escolares ou ensino aprendizagem.

Quanto aos tipos de brinquedos e objetos presentes nas brincadeiras, observamos alguns materiais industrializados como: bola de couro e elásticos coloridos, salientando que os objetos citados anteriormente foram trazidos pelos alunos e não disponibilizados pela escola. 


\section{CONSIDERAÇÕES FINAIS}

As constatações aqui apresentadas acerca do lúdico como elemento motivador na educação das crianças do campo em Atalaia-AL revelam uma ênfase em um trabalho tradicional com a língua escrita, propostas pedagógicas direcionadas a processos de escolarização tradicionais voltados para o reconhecimento e leitura de números e letras sem qualquer ligação com processos e recursos mais lúdicos de alfabetização que em geral deveriam ser comuns as crianças nessas faixas de idade, desconsiderando a ludicidade e o processo sócio- interativo, são evidentes ainda as lacunas no que diz respeito ao trabalho com outras linguagens (música, artes visuais, movimento, natureza e sociedade), tanto quanto igualmente importantes para o pleno desenvolvimento da criança, isto posto, deve-se ressaltar que foram os dias de observações feitas na Escola.

Diante do que observamos e coletamos na entrevista com as professoras entrevistadas em nossa pesquisa, percebemos que a ludicidade é pouco explorada no ambiente da sala de aula como recurso pedagógico, conciliando-se brincadeira e aprendizagem.

A professora entrevistada tem formação e embasamento para trabalhar seguindo essa metodologia, uma vez que ambas são formadas em pedagogia. Elas relatam que acreditam e consideram que o lúdico é importante para o desenvolvimento e aprendizagem dos alunos, mas que poucas vezes lhes é permitido trabalhar dessa forma fazendo um elo entre ludicidade e aprendizagem, elas apontam a falta de ferramentas como jogos disponibilizados para elas como também uma formação específica direcionada ao assunto, como também a falta de tempo para procurar atividades para fazer essa articulação entre o lúdico e os conteúdos que devem ser trabalhados durante o ano letivo, pois no final desse determinado ano elas tem que ter cumprido com todos os conteúdos que lhes foram propostos. Isso faz com que elas muitas vezes só trabalhem com o livro didático deixando à parte atividades lúdicas no cotidiano de suas aulas.

O que constatamos em nossa pesquisa é que ainda estamos longe de atingir uma educação de qualidade, uma vez que propostas como a importância do lúdico no desen- 
volvimento e aprendizagem dos alunos em sala de aula, ainda não são comtempladas por inúmeros fatores, sejam eles de punho político ou organizacional da gestão pedagógica das escolas.

\section{REFERÊNCIAS}

ALVES, Rubem. A gestação do futuro. Campinas: Papirus, 1987.

BRASIL. Ministério da Educação. Lei de Diretrizes e Bases da Educação Nacional. Lei n. 9.394/96.

BRASIL. Ministério da Educação. Resolução n 2, de 28 de Abril de 2008.

BRASIL.Ministério da Educação. Resolução nº 1, de abril de 2002.

BROUGÈRE, Gilles . Jogo e educação. Porto Alegre: Artes Médicas, 1998.

CALDART, Roseli S. Elementos para Construção do Projeto Político e Pedagógico da Educação do Campo. In MOLINA, Mônica C.; JESUS, Sonia M. S. A. de. (Orgs) Contribuições a construção de um projeto de Educação do Campo. Coleção Por Uma Educação do Campo, $n^{0}$ 5. Brasilia: Articulação Nacional Por Uma Educação do Campo, 2004.

CAMPOS, Judas Tadeu. Festas juninas nas escolas: lições de preconceitos. Revista Educação Sociedade, Campinas, vol 28, n. 99, p. 589-606, maio/ago. 2007. CEDES-UNICAMP

CORDAZZO, Sheila Tatiana Duarte, WESTPHAL, J. O. TAGLIARI, F. B. \& VIEIRA, M. L. Brincadeira em Escola de Ensino Fundamental: Um estudo observacional Revista Interação em Psicologia, 2010, 14(1), p. 43-52/UFPR

DE COSTA, Liciane \& PERIPOLLI, O. J. Educação e a infância no campo: um olhar sobre os diferentes espaços de aprendizagem. Revista Eventos Pedagógicos. V. 3, p 159-169, Ago-Dez. 2012/UNEMAT

FLICK, U. Uma introdução à pesquisa qualitativa. Porto Alegre: Bookman, 2004.

LEITE, Maria Isabel Ferraz Pereira 
FREIRE, Paulo. Extensão ou comunicação? Rio de Janeiro, Paz e Terra, 1983. (Col. O mundo hoje, v. 24).

GOSSO, Yumi, MORAIS, M. L. S. \& OTTA, E. Pivôs utilizados nas brincadeiras de faz-de-conta de crianças brasileiras de cinco grupos culturais. Revista Estudos de Psicologia 2006, 11(1), 17-24/Programa de de Pós-graduação em Psicologia da UFRN

LEITE, Isabel Ferraz Pereira Crianças do campo - os mudos da história? Revista Estudos Sociedade e Agricultura, 6, julho 1996: 170-191. UFRJ/ICHS/DDAS

LEITE, Maria Isabel Ferraz Pereira. Repensando a escola - com a palavra: a criança da área rural. Revista Pro-posições - vol 13. N. 1 (37) - Jan/Abr 2002/Faculdade de Educação UNICAMP

PIAGET, Jean. Seis estudos de Psicologia, Rio de Janeiro: Forense, 1967.

PIRES, Angela Monteiro. Educação do Campo como direito humano - São Paulo: Cortez, 2012.

REGO, T.C. Vygotsky: uma perspectiva histórico-cultural em educação. Petrópolis: Vozes, 2012.

RIBAS, Juliana da Rosa \& ANTUNES, H. S. Ludicidade no processo de construção da leitura e escrita em uma escola rural: algumas reflexões. Revista do VI Fórum Internacional de Pedagogia/Santa Maria-Rio Grande do Sul, 30 de julho a 01 de agosto de 2014. Editora Realize.

SANTOS, Ana Karina \& DIAS, A. M. Comportamentos Lúdicos entre Crianças do Nordeste do Brasil: Categorização de Brincadeiras. Revista Psicologia: Teoria e Pesquisa. Out-Dez 2010, Vol. 26 n. 4, pp 585-59/Instituto de Psicologia da UNB

SEIXAS, Angélica Amanda Campos. Brincando na Ilha dos Frades. Dissertação de Mestrado. Universidade Federal da Bahia/Faculdade de Filosofia e Ciências Humanas/ Departamento de Psicologia-Programa de Pós-graduação em Psicologia. Salvador-Ba, 2007. Biblioteca Central Reitor Macêdo Costa.

SILVA, Juliana Bezzon da, SILVA, A. P. Vivências de crianças no ambiente rural: aproximações e distanciamentos na educação infantil. Revista Latino-americana de Psicologia Volume 45 N. 3 p. 351-362. 
TEIXEIRA, Sônia Regina dos Santos \& ALVES, J. M. O Contexto das Brincadeiras das Crianças Ribeirinhasda Ilha do Combu. Revista Psicologia: Reflexão e Crítica, 21(3), 374-382/Programa de Pós-graduação em Psicologia da UFRGS

TRIVIÑOS, A. N. S. - Introdução à pesquisa em ciências sociais: a pesquisa qualitativa em educação. São Paulo, Atlas, 1987.

VIGOTSKY, L. S. A formação social da mente: o desenvolvimento dos processos psicológicos superiores. 2. ed. Porto Alegre: Martins Fontes, 1988. 
doi: 10.48209/978-65-995948-7-7

\section{GAPÍTULO 6}

e.

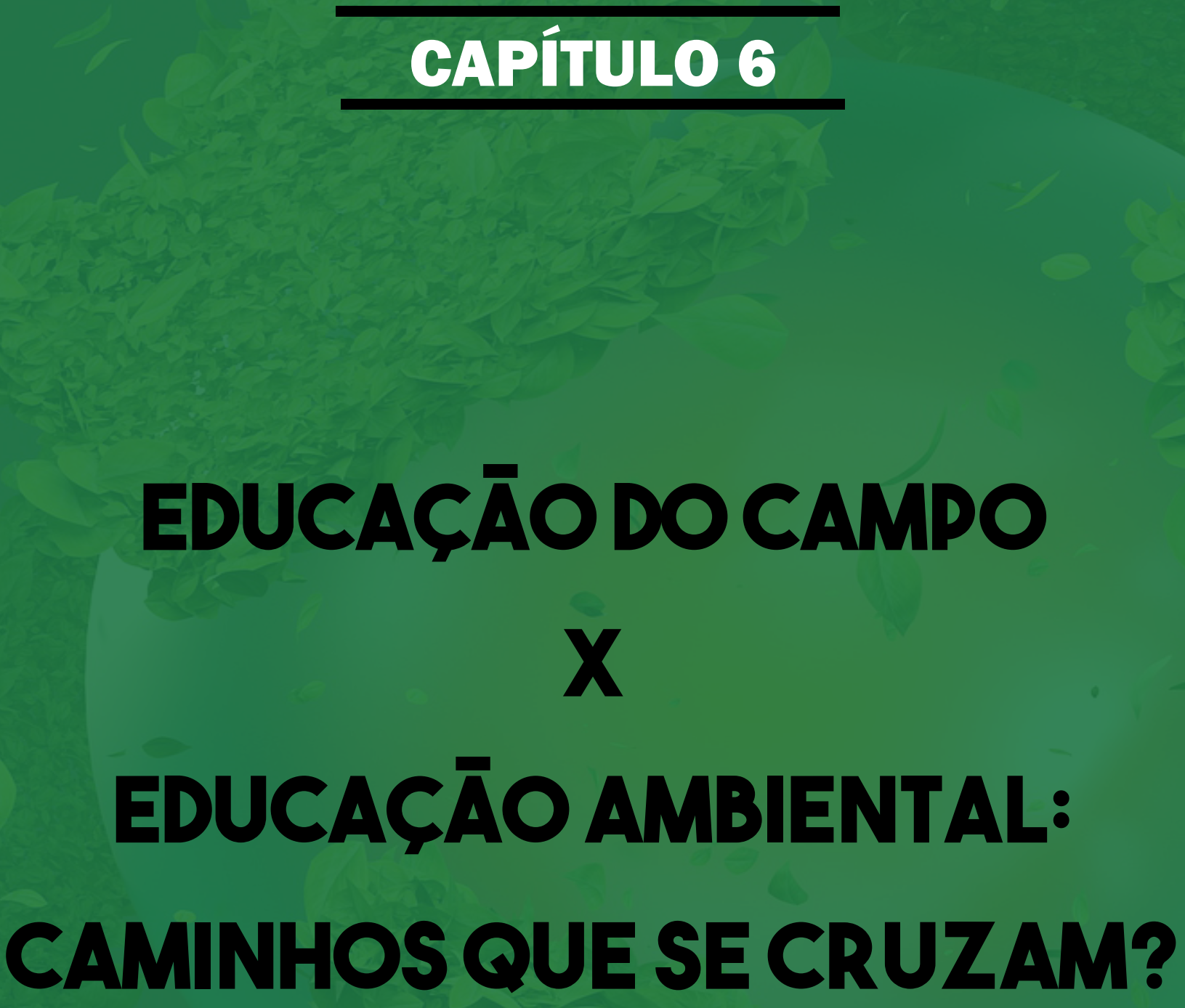

Danilo Fernandes Lobato

Renata José de Melo

Olga Matias Teles Honorato

Simara Maria Tavares Nunes Simões 
Resumo: a Educação Ambiental relacionada a Educação do Campo, possui potencialidade para formar alunos do campo críticos frente as problemáticas por eles enfrentadas. Assim, este trabalho faz parte do recorte de um Trabalho de Conclusão de Curso (TCC) intitulado: “A Dimensão Ambiental no Curso de Licenciatura em Educação Do Campo Da UFG/RC". Neste recorte os autores buscaram correlacionar concepções que envolvam a Educação do Campo com a Educação Ambiental, partindo de uma pesquisa qualitativa, envolvendo 6 egressas do curso em Educação do campo, para coleta de dados fez-se uso da entrevista semiestruturada, que foram transcritas e analisadas com base na Análise Textual Discursiva. Por meio da narrativa das egressas pode se observar que a discussão da Educação Ambiental ocorre em disciplinas ao longo do curso e que elas também tiveram a oportunidade de vivenciar atividades como palestra que discutiram a temática, o que se considera de suma importância para a formação de um educador do campo preocupado com as questões ambientais. Mesmo, com a existência da temática no curso investigado, observa-se a necessidade da ampliação dessas discussões em trabalhos acadêmicos.

Palavras-Chave: Educação do Campo, Educação Ambiental, Formação Inicial Docente

\section{CONSIDERAÇÕES INICIAIS}

É esperado que em uma graduação de licenciatura em Educação do Campo com habilitação em Ciências da Natureza a temática Educação ambiental se faça presente no currículo. Uma vez que, este curso surgiu através de anos de lutas dos movimentos sociais da terra e pela terra, então essa temática é uma das bandeiras levantadas nesses movimentos, desse modo não podemos esperar que o curso de Educação do Campo fuja a regra uma vez que esses profissionais atuaram no campo por uma Educação do Campo. Dessa forma (MOLINA; JESUS, 2004, apud NETTO; SCHULTZ, 2017, p. 5) destacam que a Educação do Campo, em conjunto com a Educação Ambiental, tem se mostrado como estratégia para transformar o espaço rural brasileiro, resgatando-o como espaço de produção, mas também de relações socioculturais, e com a natureza (MOLINA; JESUS, 2004).

Netto e Schultz (2017, p. 5) salientam que a Educação do Campo busca estabelecer a relação entre trabalho e ciência, vida escolar e vida social, através da relação entre ho- 
mem-sociedade-natureza. O vínculo com o trabalho no campo é o elemento que promove a relação da escola com a realidade (PISTRAK, 2003; CALDART, 2011).

Assim, surge a necessidade de um o curso que forme professores para atuar com esse público específico, discutindo a Educação Ambiental. Nesses termos, Miranda, Miranda e Ravaglia (2010) ressaltam a importância da Lei n. 9.795, de 27 de abril de 1999 (PNEA), onde se encontra a definição da Educação Ambiental como elemento fundamental e indelével para a educação nacional, devendo estar presente e articulada em todos os níveis e modalidades de ensino, “em caráter formal e não formal, ser desenvolvida como uma prática educativa integrada e continua envolvendo todos os professores" (MIRANDA; MIRANDA; RAVAGLIA, 2010, p. 3).

Loureiro (2003) destaca que a Educação Ambiental deve ser definida como uma práxis educativa que tem por finalidade a construção de valores, conceitos, habilidades e atitudes capazes de possibilitar o entendimento da realidade de vida e a atuação lúcida e responsável de atores sociais individuais e coletivos no ambiente. $\mathrm{O}$ autor, ainda afirma que para a real transformação do quadro de crise em que vivemos, a Educação Ambiental se define como elemento estratégico na formação ampla da consciência crítica das relações sociais que situam a inserção humana na natureza (LOUREIRO, 2006). Assim, observa-se o caráter político e transformador da Educação Ambiental, mostrando o potencial da mesma para uma formação crítica e ativa dos estudantes.

Torales (2013) traz a reflexão de que a prática da Educação Ambiental não é resultado exclusivo das políticas públicas, todavia, estas estabelecem as orientações e impulsionam projetos, programas, formação continuada de professores, material didático e outras estratégias, com maior ou menor sistematização e sucesso, para desenvolver a Educação Ambiental nas instituições de ensino, inclusive nos cursos de formação de professores nas universidades. Sendo assim, percebe-se a importância da Legislação Educacional na proposição da Educação Ambiental na prática educativa. Segundo a autora acima embora a Educação Ambiental se expanda, ela ainda é pouco abrangente e se caracteriza por ações pontuais e iniciais como prática a ser potencializada. 
Assim, o presente trabalho tem o objetivo de correlacionar a Educação do Campo com a Educação Ambiental a partir das concepções de Licenciandos do curso de Licenciatura em Educação do Campo habilitação em Ciências da Natureza.

\section{METODOLOGIA}

Trata-se de uma pesquisa de caráter qualitativo que têm em sua gênese os questionamentos sobre como está ocorrendo a formação de professores dentro da perspectiva ambiental no Curso de Licenciatura em Educação do Campo, habilitação em Ciências da Natureza, da Universidade Federal de Goiás/Regional Catalão (EDUCampo/UFG/RC).

De acordo com Bogdan e Biklen (1994, p.49), “a abordagem da investigação qualitativa exige que o mundo seja examinado com a ideia de que nada é trivial, que tudo tem potencial para constituir uma pista que nos permita estabelecer uma compreensão mais esclarecedora do nosso objeto de estudo". Esse tipo de pesquisa começou a ser praticada mais efetivamente a partir dos anos setenta, quando as agências federais de financiamentos em pesquisa manifestaram interesse por propostas que tinham a abordagem qualitativa como caráter avaliativo ao contrário de uma pesquisa de caráter quantitativo, que se propõe apenas avaliar dados numéricos, essa abordagem se baseia no estudo de crenças, significados e subjetividade.

Os questionamentos que permeia essa pesquisa, ocorreram devido ao fato de que o Curso de Licenciatura em Educação do Campo tem como princípios básicos na capacitação de professores para a docência em Ciências da Natureza para atuação nas séries finais do Ensino Fundamental e Ensino Médio em escoladas do campo. Sendo assim, por se tratar de um Curso de formação de professores para atuar no campo, deveria haver a inserção da abordagem ambiental.

1 Destaca-se que atualmente a Universidade Federal de Goiás/Regional Catalão se tornou independente passando a se chamar Universidade Federal de Catalão (UFCAT), mas como o artigo faz referência a um Trabalho de Conclusão de Curso (TCC) defendido antes dessa transição manteremos o uso do nome Universidade Federal de Goiás/Regional Catalão. 
De início, foram realizados levantamentos bibliográficos e documentais que contemplassem aspectos de ordem conceitual sobre o que é a Educação Ambiental e sobre a abordagem ambiental dentro dos Cursos de Licenciatura em Educação do Campo, além de se averiguar a Educação Ambiental na Legislação Educacional.

Para a análise da presença da Educação Ambiental em atividade de ensino, pesquisa e extensão foi realizada a coleta de dados através de entrevistas semiestruturada com 6 egressas da $1^{\text {a }}$ turma do Curso, com ingresso em 2014/1 e conclusão em 2017/2. Foram atribuídos códigos no lugar dos nomes, que foram separados por ordem alfabética e atribuídos códigos de E1 a E6 de forma a se preservar o sigilo na citação das falas.

Demo (1995) define a entrevista semiestruturada como a atividade científica que permite ao pesquisador descobrir a realidade. Por sua vez, Minayo (1996) defende ser o fenômeno que permite aproximarmos os fatos ocorridos na realidade da teoria existente sobre o assunto analisado, a partir da combinação entre ambos. Já, Trivinos (1987, p.146) esclarece que entre as principais características de uma entrevista semiestruturada, estão: apoiar-se em teorias e hipóteses que se relacionam o tema da pesquisa; descrever e explicar os fenômenos analisados para sua melhor compreensão; que o aluno/pesquisador seja atuante no processo de coleta de informações.

Em seguida, os dados coletados a partir das entrevistas que foram tratados a partir da Análise Textual Discursiva. Segundo Moraes e Galiazzi (2006), a Análise Textual Discursiva se constitui em uma abordagem do tipo qualitativa, pois se caracteriza por se aprofundar na compreensão de fenômenos que se investiga a partir de uma análise rigorosa e criteriosa; a intensão não é testar hipóteses para comprová-las ou contestá-las ao final da pesquisa, a intenção é a compreensão dos termos investigados. Os autores descrevem ainda a Análise Textual Discursiva como uma abordagem de análise de dados que transita entre duas formas importantes de análise na pesquisa qualitativa, que são a análise de conteúdo e a análise de discurso (MORAES; GALIAZZI, 2006).

Segundo os mesmos autores essa análise é descrita como: um processo que se inicia com uma unitarização em que os textos são separados em unidades de significado. 
Essa separação é feita por trechos de elementos pesquisados nas entrevistas. Estes elementos poderão ser frases, pequenos trechos e até mesmo o parágrafo todo dependendo do significado do contexto. Estas unidades por si mesmas podem gerar outros conjuntos de unidades oriundas da interlocução empírica, da interlocução teórica e das interpretações feitas pelo pesquisador (MORAES; GALIAZZI, 2006).

Neste movimento de interpretação do significado atribuído pelo autor da pesquisa exercita-se a apropriação das palavras de outras vozes para compreender melhor o texto. Assim, depois da realização desta unitarização, que foi realizada com intensidade e profundidade, fez-se a articulação de significados semelhantes em um processo denominado de categorização. "Neste processo, reúnem-se as unidades de significado semelhantes, podendo gerar vários níveis de categorias de análise” (MORAES; GALIAZZI, pag.118, 2006).

A parte final da Analise Textual Discursiva foi a Comunicação, na qual é realizada a análise do discurso através de textos que expliquem as quatro categorias. E nesse sentido que foi clareando a comunicação dos achados. Para Moraes e Galiazzi (2006) é neste movimento de interpretação dos significados atribuídos pelo pesquisador que se exercita a apropriação das palavras de outras vozes para compreender melhor o contexto. Dessa forma, a seguir apresenta-se parte das análises realizadas a partir das falas doas egressas, onde buscou-se analisar e sondar como está sendo vista a temática Educação Ambiental no Curso de Licenciatura em Educação do Campo da Universidade Federal de Goiás/ Regional Catalão.

\section{RESULTADOS E DISCUSSÃO}

A literatura referente a Educação do Campo e a relação com a Educação Ambiental é recente e ainda são poucas as publicações que discutem essa relação. As primeiras impressões sobre essas publicações (CRIBB, 2007; ONGARO, MEURER E SCHIRMER, 2016; ALVES, MELO E SANTOS, 2017) é que a Educação do Campo assim como a Educação Ambiental estão ligadas pelo fator histórico social e político referente aos 
conflitos pela terra, pela proximidade do homem do campo com a natureza, seguindo por esse viés deve-se considerar as realidades dos sujeitos e que para isso é necessário contextualizar essa educação e por final refletindo sobre os princípios que norteiam a Educação do Campo com a Educação Ambiental de certo modo são parecidos, pois em ambos os casos se busca uma educação contextualizada, reflexiva, libertária, crítica e ambientalmente responsável. Corroboram com os autores acima ao afirmar que a Educação do Campo tem relação direta com a Educação Ambiental devido às suas origens (movimentos sociais) e público alvo educandos residentes no campo, que tem ligação direta com o meio ambiente e lutam por sua preservação.

Alves, Melo e Santos (2017) evidenciam que na Educação do Campo discussões sobre as relações entre campo e da cidade, entre produção e consumo, desenvolvimento e sustentabilidade são fundamentais para a compreensão dos estudantes em relação a si e ao meio. Ainda, segundo os autores, a escola do campo deve conectar ciência e cotidiano; deve contextualizar, religar o que está separado e capacitar os estudantes para que compreendam tanto fenômenos locais quanto globais. Os autores destacam ainda que:

As escolas do campo devem repensar seu papel e direcionamento pedagógico. Temas relacionados ao trabalho, à produção, à sustentabilidade, às práticas produtivas precisam constar nos planos de aula, nos projetos de ensino, nos Projetos Políticos Pedagógicos (PPP) e Planos de Curso das instituições de ensino, uma vez que elementos sociais, políticos e econômicos são indissociáveis (ALVES; MELO e SANTOS 2017, pág. 89).

Ongaro, Meurer, Schirmer (2016) destacam também que a necessidade de uma união entre Educação Ambiental e Educação do Campo, pois entende-se que há uma inter-relação de proximidade no que tange ao tema meio ambiente. Os autores destacam ainda que:

(...) educação do campo é uma estratégia de reagir a uma ideologia que nos afasta da natureza. Além disso, ao buscar idealizar uma educação a partir do campo e para o campo, é necessário, antes de qualquer coisa, analisar e revisar conceitos adotados pelo senso comum. É necessário desconstruir preconceitos há muito tempo existentes, e arraigados na sociedade, a fim de promover uma minimização das desigualdades educacionais (ONGARO, MEURER, SCHIRMER, 2016, pg. 755). 
Quando questionadas qual a relação ou envolvimento do Curso de Licenciatura em Educação do Campo com as temática ambientais, podemos observar que nas falas das egressas elas fazem essa relação a todo o momento, enfatizam ainda que o curso surge através das lutas dos movimentos sociais, organizações estas que possuem uma maneira diferente de lidar com o meio ambiente, uma visão crítica e de valorização, pois é de lá que a grande maioria tira seu sustento. Isso pode ser constato nas seguintes falas:

Excerto 1 - O curso é completamente voltado para as questões ambientais, ele tenta trabalhar com o professor em formação, para que o mesmo ensine seus alunos de forma crítica, que o aluno saiba questionar, buscar, interpretar uma situação. [...] O Curso de Licenciatura em Educação do Campo é totalmente voltado para as questões ambientais, ou deveria ser, porque ele está interligado ao campo em todo seu contexto. Todas as disciplinas são voltadas para a educação do campo (E1).

Excerto 2 - Em um curso que emerge dos erra, porque esses militantes lutam pela sustentabilidade e tem respeito com o meio ambiente. São alunos que veem da zona rural e merecem ter esse respeito e responsabilidade por nós docentes. Eles têm contato direto com a terra (E4).

Leite (2002) acentua que o meio rural e o meio urbano são elementos diferentes; o meio rural vivencia a relação com a natureza, fato que deve ser considerado nos currículos, nos planos de ensino e nas práticas educativas: "No meio rural, trabalho e escola são responsáveis pela continuidade ou não de processos socioculturais e de produção, como o próprio trabalho, a convivência grupal e outros tantos valores" (LEITE, 2002, p.76).

Durante a entrevista questionou-se as egressas quais as disciplinas cursadas por elas abordou a Educação Ambiental. As licenciadas destacaram principalmente as disciplinas Questão Agrária e Agricultura Familiar. Outra disciplina apontada foi Agroecologia, contudo, tal disciplina não compõe a grade curricular permanente do curso e foi ofertada para a turma como Núcleo Livre. Seguem algumas falas que destacam as disciplinas que abordam a questão ambiental:

Excerto 3 - Foi trabalhada na disciplina de Agroecologia. Foi trabalhada a preservação do solo com algumas leguminosas, como fixar nitrogênio no solo, uma forma de preservação do solo e do meio ambiente (E2). 
Excerto 4- A gente discute na disciplina de Biologia, Questão Agrária e Agricultura Familiar. Eram as disciplinas que discutiam mais essa questão (E5).

Segundo a narrativa das egressas a Educação Ambiental está ligada diretamente com a Educação do Campo pelo curso ser direcionado a um público especifico da zona rural e que tal público está em contato direto com o meio ambiente. E essa relação possui conflitos. Questionou-se também se as questões ambientais foram abordadas de forma interdisciplinar, pois de acordo com elas a interdisciplinaridade envolve todo nosso cotidiano.

Excerto 5- Foi sim, acredito que em todas as disciplinas foi discutida essa questão, até porque o Curso de Licenciatura em Educação do Campo é mais voltado para essa questão da preservação do meio ambiente e da conscientização das pessoas, quanto ao uso dos agrotóxicos, do destino do lixo, preservação das nascentes, da água (E1).

Excerto 6- Sim, porque a Educação Ambiental não está pautada somente na disciplina de Biologia, Ciências, ela engloba todas as disciplinas como exemplo na área das exatas e o nosso cotidiano, eu pude vivenciar essa realidade em sala de aula. A Educação Ambiental precisa ser trabalhada e contextualizada de maneira mais clara em ambas as disciplinas (E6).

Excerto 7- Sim, conforme havia dito anteriormente ela cabe em todas as disciplinas e em todos os cursos, principalmente para o Curso de Licenciatura em Educação do Campo, sendo este um curso especifico para o campo e para além disso, um curso que é trabalhado de maneira interdisciplinar e quando se fala em interdisciplinaridade, envolve-se tudo o que está ao nosso redor, desse modo, o meio ambiente está inserido em todos os aspectos no nosso dia-dia (E6).

Assim, as entrevistadas, deixam evidente que o Curso de Licenciatura em Educação do Campo está totalmente envolvido com a temática Educação Ambiental:

Excerto 8- O curso é completamente voltado para as questões ambientais. Ele tenta trabalhar com o professor em formação para que o mesmo ensine seus alunos de forma crítica, que o aluno saiba questionar, buscar, interpretar uma situação (...) ou deveria ser, porque ele está no campo em todo seu contexto. Todas as disciplinas são voltadas para a educação do campo (E1).

Excerto 10- É um assunto de suma importância e este deve ser discutido com mais frequência na formação escolar e acadêmica, porque o docente precisa estar preparado para enfrentar essas destruições que estão acontecendo no meio ambiente para que o ser humano seja conscientizado (E2). 
De acordo com os entrevistados no que diz respeito a importância da Educação Ambiental em sua formação para atuarem na prática pedagógica, as falas têm em comum o compromisso com a educação escolar e com a sociedade, ou seja, a responsabilidade social. Porém, destacam que precisam ter mais subsídios para que essa teoria se torne efetiva. Para tanto, afirmam que se faz necessário acrescentar no currículo do curso uma disciplina específica que aborde a temática de maneira efetiva. Trechos da entrevista nos fazem concluir que a temática não foi trabalhada em todas as disciplinas:

Excerto 11 - Desse modo, a temática foi trabalhada conosco enquanto formação de professores, conforme dito anteriormente. Não em todas, mas em algumas disciplinas trabalhou-se a questão ambiental (El).

Excerto 12- Apesar de ter visto muitas questões ambientais, nós não tivemos uma matéria especifica na área. Eu acho que faltou isso (E4).

Excerto 13 - Acredito que deveria ser abordado com mais ênfase o tema, para o docente estar preparado para Iidar com a sociedade, teria que ter uma disciplina especifica para trabalhar esse assunto que hoje é um grande problema para a sociedade (E2).

A Educação Ambiental não se limita ao Ensino de Biologia e ao Ensino de Ciências e também não se caracteriza como ensino para modificar comportamentos ambientais ilegais. $\mathrm{O}$ que temos hoje, por parte daqueles que têm uma concepção mais crítica de Educação Ambiental é a ideia de que é um processo de construção da relação humana com o ambiente onde os princípios da responsabilidade, da autonomia, da democracia, entre outros estejam sempre presentes (TOZONI-REIS, 2002). Algumas falas destacam que as discussões de temas ambientais deveriam ser discutidas de forma mais efetivas nas escolas:

Excerto 14 - Porque se trabalha na Questão Agrária, Ciências, Biologia, Química, mas seria importante trabalhar com uma disciplina especifica também. Conforme foi falado anteriormente, seria bom na escola de Excerto 15 - Ensino Regular essa disciplina de "Educação ambiental" voltada exatamente para essa temática (E1).

Desse modo, podemos avaliar que as egressas fizeram ligações que estão relacionadas ao que traz a literatura. Dessa forma acredita-se se que futuramente teremos discussões em relação a temática um olhar mais denso e de outros ângulos, uma vez que 
futuros mestrandos e doutorandos já estarão atuando e trazendo suas experiências para a educação básica e superior.

Ainda segundo a narrativa das egressas o curso ainda promoveu palestras que abordram a temática ambiental, acredita-se que a formação inicial dos professores ocorre para além da sala de aula em atividades como eventos, palestras, minucursos, que são a oportunidade dos licencindos terem contato com temática que são pouco discutidas nas discplinas tais como a Educação Ambiental.

Assim, pela análise das entrevistas pode-se observar que a Educação Ambiental está inserida no Curso de Licenciatura em Educação do Campo da Universidade Federal de Goiás/Regional Catalão, tanto em algumas disciplinas como em atividades de extensão.

Excerto 6- Foi sim, a gente teve participação em vários eventos, tivemos uma palestra, se não me engano, foram duas ou três aulas com o professor convidado da UFG e ele abordou a questão do lixo, que é atualmente um problema muito sério tanto nas pequenas, quanto nas grandes cidades (E1).

O que demostra mais uma vez que a Educação Ambiental vem sendo incoporada no curso de Licenciatura em Educação do Campo da Universidade Federal de Goiás/Regional Catalão (UFG/RC), o que acreditamos ser de grande importância para a formação de um educador do campo preocupada com as discusões das temáticas ambientais com os seus alunos.

\section{CONSIDERAÇÕES FINAIS}

Conclui-se que embora não tenha encontrado muitos trabalhos que trazem a relação do curso de Licenciatura em Educação do Campo com a Educação Ambiental é notório que as egressas fazem uma leitura semelhante a literatura, tal relação é baseada referente ao público alvo da Educação do Campo que é um público que tem um vínculo direto com o meio ambiente e que por tal motivo pode ter uma concepção crítica de Educação Ambiental. 
Tratando-se de um curso novo espera-se que os futuros mestrandos e doutorandos possam a partir de suas experiências e reflexões abordar a relação da Educação do Campo x Educação Ambiental por outras vertentes e de maneira mais densa. A expectativa que se tem é que essa pesquisa possa contribuir para que o curso busque ainda mais trabalhar ainda mais a questão ambiental para uma formação cidadã e crítica e, assim, capacitar cidadãos ambientalmente críticos e responsáveis por desenvolverem pesquisas e desenvolver tecnologias sustentáveis para o planeta.

\section{REFERÊNCIAS}

ALVES, C. G. R., MELO, L. C. B., SANTOS, V. M. S. A., Educação do campo e educação ambiental: interconexões possíveis para a construção de um ensino crítico e transformador. Debates em Educação Vol. 9, Nº 18, pag. 88 - 97, Ano 2017.

BOGDAN, R., BIKLEN, S. K., Investigação qualitativa em educação. Porto, Portugal: Porto Editora, LTDA, 1994.

BRASIL. LEI N ${ }^{0}$ 9.795, DE 27 DE ABRIL DE 1999. Dispõe sobre a Política Nacional de Educação Ambiental. 1999. Disponível em: http://www.mma.gov.br/port/conama/ legiabre.cfm?codlegi=321 Acesso em: 20 de março de 2022.

CALDART, R. Por uma Educação do Campo: traços de uma identidade em construção. In ARROYO, M.; CALDART, R. S.; MOLINA, M. C (organizadores). Por uma educação do campo 5. Ed. Petrópolis, RJ: Vozes, 2011.

CRIBB, S. L. S. P. A horta escolar como elemento dinamizador da educação ambiental e de hábitos alimentares saudáveis. In: Anais do VI Encontro Nacional de Pesquisa em Educação em Ciências, 2007, Florianópolis. VI Encontro Nacional de Pesquisa em Educação em Ciências. Florianópolis, 2007.

DEMO, P. Metodologia científica em ciências sociais. 3a Ed., São Paulo, Atlas, 1995.

LEITE, S. C. Escola rural: urbanização e políticas educacionais. 2. ed. São Paulo: Cortez, 2002.

LOUREIRO, C. F. B., Cidadania e meio ambiente. Salvador: Centro de Recursos Ambientais, 2003. 
LOUREIRO, C. F. B. Complexidade e dialética: Contribuições à práxis política e emancipatória em educação ambiental. Educação \& Sociedade, Campinas, vol. 27, n. 94, p. 131-152, jan./abr. 2006.

MINAYO, M. C. S. O desafio do conhecimento: pesquisa qualitativa em saúde. 3.ed. São Paulo: Hucitec/Rio de Janeiro: Abrasco, 1996.

MIRANDA, F. H. F. MIRANDA, J. A. RAVAGLIA, R. Abordagem interdisciplinar em Educação Ambiental. Revista Práxis, ano 2, n. 4, ago. 11-16, 2010.

MOLINA, M. C.; JESUS, S. M. Por uma Educação do Campo. Brasília, 2004.

MORAES, R., GALIAZZI, M. C. Análise textual discursiva: processo reconstrutivo de múltiplas faces. Ciência \& Educação, v. 12, n. 1, p. 117-128, 2006.

NETTO, D. SCHULTZ, G. APROXIMAÇÕES ENTRE A EDUCAÇÃO DO CAMPO E A EDUCAÇÃO AMBIENTAL NOS CENTROS FAMILIARES DE FORMAÇÃO POR ALTERNÂNCIA. \# Tear: Revista de Educação Ciência e Tecnologia, Canoas, v.6, n.2, 2017.

ONGARO, M. D., MEURER, A. C. SCHIRMER, G. J. A relação da Educação Ambiental e a educação do campo. Anais II Cong. Int. Uma Nova Pedagogia para a Sociedade Futura. set. 2016.

PISTRAK, M. M. Fundamentos da Escola do Trabalho. São Paulo: Expressão Popular, 2003.

TORALES, M. A. A inserção da Educação Ambiental nos currículos escolares e o papel dos professores: da ação escolar à ação educativo-comunitária como compromisso político-pedagógico. Revista Eletrônica do Mestrado em Educação Ambiental, Rio Grande/RS, v. especial, p. 1-17, mar. 2013.

TRIVINOS, A.N.S. Introdução à pesquisa em ciências sociais: a pesquisa qualitativa em educação. São Paulo: Atlas, 1987. 
doi: 10.48209/978-65-995948-7-1

\title{
GAPITULO 7
}

\section{AEDUCAC̄ĀO AMBIENTAL}

EM ESPAÇOS NĀO FORMAIS

DA EDUCAÇĀO INFANTIL:

\section{PROPOSTAS DE METODOLOGIAS}

\section{TRANSFORMADORAS'}

\author{
Alex de Lima e Silva \\ Evandro José Branches Lopes Filho \\ Paulo Roberto Valdo Thomaz \\ Patricia Laurindo da Cunha Passos \\ Patrícia Vasconcelos Costa \\ Rose Cléia Maria Barros Mendes
}

1 Atividade realizada como requisito avaliativo para a conclusão da Disciplina: Desarrollo y Educación Ambiental, ministrada pela Professora Doutora Paloma Martins Mendonça (Instituto IDEIA e Universidad Columbia del Paraguay - PY). 
Resumo: O trabalho a seguir é o resultado de uma análise de recursos e métodos em que a educação ambiental se faz presente em espaços não formais que envolvem o público da educação infantil. Os bebês e as crianças da sociedade pós-moderna se apresentam sujeitos cada vez mais críticos e capazes de aprender hábitos conscientes de cuidados e preservação do meio ambiente. Entende-se que um dia, essas crianças serão adultas e poderão contribuir de forma significativa e agir de modo naturalizado em prol de uma sociedade mais sustentável para o bem comum. A educação ambiental não é apenas responsabilidade da escola, por isso, é fundamental que toda a sociedade se disponha de vários recursos que estimulem e agregam conhecimentos para a vida de preservação mais sustentável, como a utilização da tecnologia, de brinquedos sustentáveis, espaços públicos, igrejas, entre outros, que oportunizam o desenvolver da criticidade e conscientização ambiental além dos muros da escola.

Palavras-chave: educação ambiental; educação infantil; espaço não formal; conhecimento.

Abstract: The following work is the result of an analysis of resources and methods in which environmental education is present in non-formal spaces that involves the public of early childhood education. The babies and children of postmodern society self-present individuals increasingly criticals and able to learn about consciousness habits of environment care and preservation. It is understood that one day, those children will become adults and could contribute in a significantly and act in a naturalized way towards to more sustainable society for the common good. The environment education is not only school responsibility, so it is essential that the hole society prepares itself with various resources to stimulate and add knowledge for a more sustainable preservation life, such as the use of green information technology, sustainable toys, public spaces, church's, among others, that provide the opportunity to develop criticism and environmental consciousness beyond school walls.

Keywords: ambiental education; childhood education; non formal space; knowledge.

\section{INTRODUÇÃo}

Os temas do trabalho, em questão, têm como objetivo propor uma análise sobre a importância do espaço da educação não formal e a educação ambiental voltada para o público infantil. A priori nos últimos anos têm sido temas atuais nas discussões de debate, mesas redondas, lives e estudos entre os profissionais da educação. 
As reflexões partiram de análises e estudos em grupo no qual promoveu a compreensão da teoria e os conceitos para uma possível intervenção em uma comunidade onde o indivíduo está inserido. A pesquisa nos propiciou na elaboração deste trabalho, uma reflexão a partir da observação do ambiente que promove a educação não formal do profissional que atua nesse espaço e das ações que ali são desenvolvidas.

Por conseguinte, as referências bibliográficas reconhecem este espaço como um processo de ensino/aprendizagem, no qual a educação não se limita apenas aos muros da escola, nesse sentido, os processos formativos auxiliam os diferentes grupos sociais no qual a temática será introduzida.

Ao fazer um gancho da educação não formal e as questões da educação ambiental fora da sala, nos remete ao processo de aprendizado e as reflexões dos conceitos multiculturais e interdisciplinares, tornado uma necessidade e uma preocupação quanto às soluções que se pretendem para garantir uma melhor qualidade de vida às gerações futuras.

A educação ambiental, através de um processo pedagógico equivalente, procura agregar ao educando uma consciência crítica sobre os problemas do meio ambiente auxiliando-o a criar consciência de uma educação preocupada não somente com o bem-estar individualizado, mas com todos, fazendo-o buscar transformações na sociedade onde está inserido.

\section{A EDUCAÇÃo AMBIENTÃ NOS ESPAÇOS NÃo FORMAIS PARA EDUCAÇÃO INFANTIL}

No que se refere à importância da Educação Ambiental e suas práticas, busca-se compreendê-las como ações que refletem um pensamento crítico que vai além da transmissão de conhecimentos rotulados em conceitos e dos espaços escolares. Essa perspectiva se deleita ao pensamento de Jacobi (2003, p. 191) em que:

A realidade atual exige uma reflexão cada vez menos linear, e isto se produz na inter-relação dos saberes e das práticas coletivas que criam identidades e valores comuns e ações solidárias diante da reapropriação da natureza, numa perspectiva que privilegia o diálogo entre saberes. 
O que nos leva a considerar como fundamental as vivências ambientais desde a infância se desdobrando na construção de uma consciência ambiental individual e coletiva.

Faz-se necessário o entendimento sobre como se dá educação ambiental em espaços não- formais, e para isso recorremos à Libâneo (2002) que refere-se a educação não-formal às organizações políticas, profissionais, científicas, culturais, agências formativas para grupos sociais, educação cívica etc., com atividades de caráter intencional preocupada com realidades sociais. As práticas nesses espaços não-formais tais como: associações comunitárias, ONG's, pastorais, movimentos sociais, canais virtuais e televisivos, programas e projetos; devem desenvolver ações permanentes, a fim de oportunizar a criança sentir, ver, ouvir e perceber seus contextos para desenvolver competências fundamentais para sua atuação consciente mediante às emergências ambientais.

São nestes espaços que, muitas vezes, a criança tem suas primeiras vivências com as problemáticas referentes ao meio ambiente e a ação do homem, este, como o principal agente de destruição desses referidos espaços naturais. Vale ressaltar que Educação Ambiental por meio de Projetos Sociais, neste contexto, tem como foco a conscientização da comunidade escolar sobre o meio ambiente a partir de oficinas artesanais, culturais, esportivas e recreativas, decorrente a ações meramente assistencialistas, transmitindo e agregando valores, crenças, diretrizes ou propostas que busquem direcionar a práxis de um determinado movimento ou grupo que tenha influências positivas em todo ambiente no qual está inserido.

Pensando assim, é fundamental apresentar que de acordo com o Art. $1^{\circ}$ da Lei Federal n 9.795, de 27 de abril de 1999: entende-se por educação ambiental os processos pelos quais o indivíduo e a coletividade constroem valores sociais, conhecimentos, habilidades, atitudes e competências voltadas para a conservação do meio ambiente, bem de uso comum do povo, essencial à sadia qualidade de vida e da sua sustentabilidade (BRASIL, 1999).

Em face disso Paulo Freire (1996) nos dá uma luz com seu pensamento de que: "O homem não pode participar ativamente na história, na sociedade, na transformação da 
realidade se não for ajudado a tomar consciência da realidade e da sua própria capacidade de transformar". Em se tratando de formação de consciência, isso só é possível por meio desses confrontos do sujeito como aquele capaz de mudar a si e ao meio onde vive, num diálogo coletivo com outros.

Com base em toda essa compreensão apresentada, consideramos oferecer às crianças desde a educação infantil vivências com aspectos pedagógicos fundamentais da educação ambiental em torno de seu cotidiano, mobilizando ações concretas em sua vida e na relação com o meio ambiente, agora e futuramente. Precisa-se enxergar nas crianças seu potencial, valorizando o seu papel de protagonista dessa aprendizagem, pois, mesmo na fase em que se encontram são agentes ativos e colaboradoras para a racionalização de recursos que podem contribuir na preservação do ambiental mediante as contribuições ecológicas de mundo mais sustentável e melhor para as suas gerações advindas.

Para as diferentes gerações a Educação Ambiental tem um papel crucial diante de todos e deve ser ação em todos os espaços, famílias, igrejas, movimentos sociais, ONGs, associações, escolas, universidades e etc.

Estamos vivendo até então problemas ambientais no mundo inteiro e sem a intervenção concreta da humanidade para evitar e/ou reduzir os mesmos, isso tende a piorar e prejudicar a vida humana. Tendo em vista que as crianças de hoje terão grandes desafios e responsabilidades ambientais num futuro bem próximo, como por exemplo, problemas da escassez de água e poluição do ar, faz-se necessário uma educação transformadora. Portanto, quanto mais cedo abordamos com as crianças questões importantes e que se configuram como educação ambiental, ter-se-á maiores possibilidades de despertar a consciência pela preservação e hábitos sustentáveis.

O que dá esperança para conseguir mudar o cenário atual do meio ambiente e dos indivíduos como parte deste, é considerar a possibilidade concreta de práticas que iniciam da infância nos diferentes espaços sociais, dado que será melhor elucidado a seguir.

Ao ouvirmos a palavra "educação", em geral nos reportamos automaticamente 
para tópicos, exemplos e teorias sobre a educação formal, uma vez que ela está intimamente ligada ao âmbito escolar. Ainda é vista como a estrutura física na qual as atividades escolares acontecem e normalmente é a nossa primeira referência para começar a detalhar sobre o que compreendemos por educação. Após esse reporte, costumamos nomear estudantes e professores que dão vida e sentido a essa estrutura.

Porém, é preciso compreender e falar de educação não formal a partir de uma forma mais simplificada, sobretudo, fazendo uma comparação com o que já conhecemos e observar mais detalhadamente sobre os três tipos de educação no processo evolutivo do indivíduo: a formal, a informal e não formal.

É importante aclarar que a educação formal tem menos a ver com esse espaço físico que costumamos lembrar, no entanto os requisitos da estrutura formal são: ementa, divisão por disciplinas, currículo, organização em séries ou níveis gradativos baseados em idades e o controle de frequência, sistema de aprovação e reprovação, avanço de níveis, diploma e certificação.

Na educação formal também podemos salientar que há uma série de papéis definidos, com uma hierarquia clara entre professoras, diretores, coordenadoras pedagógicas e alunos. Ficando nítida essa rígida estrutura que está prevista em lei e, no nosso caso do Brasil, é de competência do Ministério da Educação (MEC). Assim sendo, percebe-se que a educação formal tem a ver com a educação institucionalizada além de ser regida por normas.

Por outro lado, a educação informal é o outro extremo, ou seja, é tudo aquilo que assimilamos no decorrer da nossa vida de forma contínua e não obrigatoriamente estruturada, especialmente através da socialização entre os indivíduos. São aprendizados vindos das experiências e interações entre os vários ambientes diversos, tais como: a amizades, os vínculos familiares, relações profissionais etc.

Por fim, a educação não formal está no meio termo entre a educação formal e informal, mas realiza-se fora do sistema formal de ensino (escola). Diante dos três tipos de 
educação, é o que menos tem consonância, por conta dos diversos formatos e abordagens que pode assumir. No geral, abrange experiências organizadas bem como possui alguma estrutura, dessa forma tem um conteúdo programático, uma metodologia, facilitação ou formas de avaliação que não lidam com notas ou avanço de séries, pois nela a estrutura é muito mais flexível do que na educação formal, ajustável ao longo do processo evolutivo dentro da educação. Neste sentido, a educação vai além do espaço delimitado pelos muros escolares e salas de aula.

O indivíduo no decorrer de toda sua trajetória de vida produzindo conhecimentos recebidos a partir das suas próprias experiências, seja por relações sociais com os outros, no âmbito familiar e em nas demais instituições educadoras formais e não formais. Assim sendo o processo de aprendizagem social centraliza no indivíduo, perpassa para além do desenvolvimento de atividades extraescolares. A criança aprende com a prática que lhe é apresentada fora dos espaços pedagógicos. Assim faz-se necessário esse aprendizado devido a importância que se dá no processo educacional evolutivo que prioriza a prática de atividades culturais, de criação, esportes, rodas de conversas, relações de trocas de vivências, entre diversas outras atividades educacionais.

A educação não-formal pode desenvolver-se nos mais variados espaços, sendo uma modalidade crescente no cenário nacional e pouco explorada nos meios acadêmicos uma vez que o desconhecimento e/ou a prática de sala de aula continuam voltada para o desenvolvimento do educando a partir da sala de aula tradicional.

A consolidação das habilidades na Educação Infantil, segundo a BNCC, apresenta uma nova concepção, um novo olhar que une o educar e o cuidar, inferindo o cuidado como algo intrínseco do processo educativo individual de cada criança. Nesse contexto, as creches e pré-escolas em todo o território nacional, ao acolher as vivências em grupo e os conhecimentos construídos pelas crianças no ambiente da família e na comunidade na qual está inserida faz-se necessário trabalhar propostas pedagógicas dentro e fora das instituições de ensino de uma forma Interdisciplinar já nos primeiros anos de formação da primeira infância. 
Neste sentido, o principal objetivo pedagógico da Educação Ambiental é ampliar o universo de experiências, conhecimentos e habilidades dessas crianças, diversificando e consolidando novas aprendizagens a partir de suas experiências concretas.

Ao ouvirmos a palavra "educação", em geral nos reportamos automaticamente para tópicos, exemplos e teorias sobre a educação formal, uma vez que ela está intimamente ligada ao âmbito escolar. Ainda é vista como a estrutura física na qual as atividades escolares acontecem e normalmente é a nossa primeira referência para começar a detalhar sobre o que compreendemos por educação. Após esse reporte, costumamos nomear estudantes e professores que dão vida e sentido a essa estrutura.

Porém, é preciso compreender e falar de educação não formal a partir de uma forma mais simplificada, sobretudo, fazendo uma comparação com o que já conhecemos e observar mais detalhadamente sobre os três tipos de educação no processo evolutivo do indivíduo: a formal, a informal e não formal.

É importante aclarar que a educação formal tem menos a ver com esse espaço físico que costumamos lembrar, os requisitos da estrutura formal são: ementa, divisão por disciplinas, currículo, organização em séries ou níveis gradativos baseados em idades e o controle de frequência, sistema de aprovação e reprovação, avanço de níveis, diploma e certificação.

Na educação formal também podemos salientar que há uma série de papéis definidos, com uma hierarquia clara entre professoras, diretores, coordenadoras pedagógicas e alunos. Ficando clara essa rígida estrutura que está prevista em lei e, no nosso caso do Brasil, é competência do Ministério da Educação (MEC) (Base, 2017). Assim sendo, percebe-se que a educação formal tem a ver com a educação institucionalizada e é regida por normas.

Por outro lado, a educação informal é o outro extremo, ou seja, é tudo aquilo que assimilamos no decorrer da nossa vida de forma contínua e não obrigatoriamente estruturada, especialmente através da socialização entre os indivíduos. São aprendizados vindos 
das experiências e interações entre os vários ambientes diversos, tais como: a amizades, os vínculos familiares, relações profissionais etc.

Por fim, a educação não formal está no meio termo entre a educação formal e informal, mas realiza-se fora do sistema formal de ensino (escola). Diante dos três tipos de educação, é o que menos tem consonância, por conta dos diversos formatos e abordagens que pode assumir. No geral, abrange experiências organizadas e que têm alguma estrutura, dessa forma tem um conteúdo programático, uma metodologia, facilitação ou formas de avaliação que não lidam com notas ou avanço de séries, pois nela a estrutura é muito mais flexível do que na educação formal, ajustável ao longo do processo evolutivo dentro da educação. Neste sentido, a educação vai além do espaço delimitado pelos muros escolares e salas de aula.

O indivíduo no decorrer de toda sua trajetória de vida produz conhecimentos recebidos a partir das suas próprias experiências, seja por relações sociais com os outros, no âmbito familiar e em nas demais instituições educadoras formais e não formais. Assim sendo o processo de aprendizagem social centraliza no indivíduo, perpassa para além do desenvolvimento de atividades extraescolares. A criança aprende com a prática que lhe é apresentada fora dos espaços pedagógicos. Assim faz-se necessário esse aprendizado devido a importância que se dá no processo educacional evolutivo que prioriza a prática de atividades culturais, de criação, esportes, rodas de conversas, relações de trocas de vivências, entre diversas outras atividades educacionais.

A educação não-formal pode desenvolver-se nos mais variados espaços, sendo uma modalidade crescente no cenário nacional e pouco explorada nos meios acadêmicos uma vez que o desconhecimento e/ou a prática de sala de aula continuam voltada para o desenvolvimento do educando a partir da sala de aula tradicional.

A consolidação das habilidades na Educação Infantil, segundo a BNCC (Base, 2017), apresenta uma nova concepção, um novo olhar que une o educar e o cuidar, inferindo o cuidado como algo intrínseco do processo educativo individual de cada criança. 
Nesse contexto, as creches e pré-escolas em todo o território nacional, ao acolher as vivências em grupo e os conhecimentos construídos pelas crianças no ambiente da família e na comunidade na qual está inserida faz-se necessário trabalhar propostas pedagógicas dentro e fora das instituições de ensino de uma forma interdisciplinar já nos primeiros anos de formação da primeira infância.

Neste sentido, o principal objetivo pedagógico da Educação Ambiental é ampliar o universo de experiências, conhecimentos e habilidades dessas crianças, diversificando e consolidando novas aprendizagens a partir de suas experiências concretas.

Nos últimos anos a vinculação de atividades em espaços não formais de educação vem ganhando destaque no Ensino de Ciências. Segundo Borges (2012) o ensino de ciências tem um papel fundamental no processo de desenvolvimento da criança, particularmente no aspecto da aprendizagem para vida, onde a criança não se limita a cumprir regras e metas sem significado, mas que sejam capazes de pensar de maneira lógica sobre os fatos do cotidiano e resolva problemas práticos da vida.

No ponto de vista ambiental, como as crianças irão cuidar daquilo que não conhecem? Em 2019, segundo Hoshino (2020) um monitoramento de canais pagos realizado pelo programa Criança e Consumo identificou que $71 \%$ da publicidade infantil é destinada a brinquedos. Considerando que, em todo o mundo, $90 \%$ dos brinquedos são feitos com plástico, é possível calcular o impacto de uma infância estimulada pelo consumo de passatempos descartáveis. É preciso, antes de tudo, que as crianças resgatem a vontade de estar perto da natureza e de preservá-la, como aponta as Diretrizes Curriculares Nacionais da Educação Infantil (Base, 2017):

As crianças precisam brincar em pátios, quintais, praças, bosques, jardins, praias, e viver experiências de semear, plantar e colher os frutos da terra, permitindo a construção de uma relação de identidade, reverência e respeito para com a natureza. Elas necessitam também ter acesso a espaços culturais diversificados: inserção em práticas culturais da comunidade, participação em apresentações musicais, teatrais, fotográficas e plásticas, visitas a bibliotecas, brinquedotecas, museus, monumentos, equipamentos públicos, parques, jardins (BRASIL, 2009, p. 15). 
Mas não adianta estimular o convívio da criança com a natureza se estes espaços são escassos nos centros urbanos. É fundamental pressionar e quebrar os estereótipos que associam a natureza a lugar de terra suja e bicho perigoso. Faz-se necessário políticas e iniciativas populares que ampliem e estimulem o acesso da sociedade a áreas verdes nas cidades. Segundo Hoshino (2020) "as áreas verdes devem estar equipadas para estimular o aprendizado entre as crianças, com trilhas sensoriais, espaços recreativos, instrumentos interativos e lúdicos" em que se apresentam grandes possibilidades de se trabalhar por meio das visitas, onde os espaços e brincadeiras são provocadoras de reflexão tanto para os adultos quanto para as crianças sob uma consciência de preservação do meio.

Segundo Sarmento (2005) há uma reflexão sobre um novo olhar que aborda as crianças, também, como atores sociais e as especificidades da docência de zero a seis anos, e Corsaro (2011) argumenta que o espaço público visa oferecer às crianças experiências ricas e diferentes da alcançabilidade que o espaço privado (residências), pode oferecer.

Pelo exposto, faz-se necessário apresentar práticas e/ou recursos metodológicos que estimulem e manifestem a educação ambiental em espaços não formais para crianças pertencentes ao público da educação infantil.

\section{UMA PROPOSTA DE EDUCAC̆̃̃O NÃO-FORMAL: O ESPAÇO DA CRIANÇA "ANÁlIA FRANCO"}

Fazendo-se uma análise temporal sobre o assunto, pode-se perceber que na segunda metade do século XX surge um discurso pedagógico reformista que convida a uma nova modalidade de educação, a educação popular ou não-formal. Este novo discurso, embasado por uma conjuntura de fatores, derruba o paradigma do modelo tradicional, no qual a escola detinha a exclusividade do processo educativo. Além disso, nesta mesma época surge uma forte crítica à escola formal, por não conseguir levar os alunos a fazerem uma leitura clara da realidade, nem lhes dar ferramentas para superá-las (Gohn, 1991; apud GHANEM et al., 2008). 
Sob a ótica da educação não formal Gohn (1991) percebe o surgimento e expansão da mesma que contribui para os movimentos sociais que passaram a suscitar reflexões acerca das desigualdades de oportunidades a que estava sujeita uma significativa parcela da população relegada à margem de importantes conquistas sociais, econômicas e culturais. Esses movimentos sociais se mobilizaram a favor da expansão das oportunidades educativas, como forma de garantir o pleno desenvolvimento da cidadania. Esta mobilização alcançou maior impacto a partir dos anos setenta e sua matriz conceitual baseava-se no ideal de esclarecer os cidadãos sobre os seus direitos, através da difusão de informações que seriam úteis para que as classes marginalizadas pudessem superar as desigualdades sociais.

Segundo Esteves e Montemór (2011), a educação não-formal é caracterizada por um conjunto de aspectos que a distingue da educação praticada nas escolas sob a égide das políticas educacionais oficiais. Para estes autores estes aspectos vêm sendo analisados por vários outros autores que a caracterizam por um conjunto de ações que acontecem em espaços próprios, com objetivos diversos, entre eles o de educar para a cidadania, para a autonomia, para os direitos humanos e para a obtenção da cultura acumulada pela humanidade.

Já no Brasil, a expansão da educação não-formal coube aos movimentos sociais que suscitam reflexões acerca das desigualdades a que estava sujeita uma parcela significativa da população, pulverizando-se, posteriormente, através de setores diversos da sociedade, como as igrejas, institutos, fundações, comunidades de bairro, empresas e ONGs. Para Esteves e Montemór (2011) que apresentam em seu trabalho um estudo de caso com uma proposta de educação não-formal correlacionando o Espaço da Criança Anália Franco, apresenta-se a contribuição de um espaço de educação não-formal, discutindo-se questões pertinentes aos seus referenciais teóricos, metodologia e mecanismos avaliativos. Os autores fazem uma correlação sobre a educação formal e educação não-formal sendo uma essencial à outra. Mediante a importância da educação formal percebe-se que a educação não-formal subsidia uma boa educação formal. Nesse estudo de caso, o Espaço da Criança Anália Franco conseguiu criar e estabelecer um ineditismo 
quando criou parcerias e alianças estratégicas com empresas privadas que têm primado pelo respeito à cultura da comunidade local, aos referenciais ideológicos da instituição promotora (Espaço da Criança), sem descuidar-se da escolarização formal. Adicionalmente, as alianças com a Secretaria de Educação e Cultura do Município e com a Diretoria de Ensino têm possibilitado a manutenção de um espaço que vem primando pela promoção do aluno, da família, da escola e da comunidade.

\section{CANAL NO YOUTUBE: JOÃO AMBIENTE - AGORA É A HORA DE UM MUNDO MELHOR}

Com o avanço do uso das ciências tecnológicas nos últimos tempos, notamos que é muito comum encontrar crianças manuseando dispositivos eletrônicos como: celular, tablet e computador; como forma de interação, distração e até mesmo brincadeira. Assim, de forma lúdica, as crianças dominam os mesmos causando a impressão de como já "nascessem sabendo manusear" tais recursos, tendo facilidade e interesse no aprendizado de como usá-los.

Juntamente com esses dispositivos, o acesso a internet também é muito comum. Crianças de 1 a 5 anos têm a liberdade de mexer nos aparelhos celulares de seus pais ou, em alguns casos, já possuem tablets presenteados por seus responsáveis com o objetivo de ser um recurso lúdico ou uma forma de passatempo.

A internet rompeu com a ideia de tempo próprio para a aprendizagem. $\mathrm{O}$ espaço da aprendizagem é aqui, em qualquer lugar; o tempo de aprender é hoje e sempre. Portanto, além das instituições de ensino formais, os espaços domiciliar e social tornaram-se educativos, uma vez que cada vez mais pessoas buscam, fora das escolas, informações nas redes de computadores interligados, serviços que respondem às suas demandas pessoais de conhecimento. (Gadotti, 2005, p.3 apud Stadler, 2019. p.123).

Assim, tendo a oportunidade de interagir com esse campo cibernético, o mundo virtual apresenta diversas ferramentas/métodos que auxiliam muito uma educação não formal para indivíduo, em especial as crianças pertencentes ao público infantil. Uma dessas ferramentas, é a plataforma YouTube. O site permite que os usuários compartilhem vídeos e interajam com seus autores através de comentários e curtidas (Canaltech, 2012). 
Na plataforma, há vários vídeos que tratam de assuntos diversos, como músicas, clipes, coreografias, conteúdos políticos, escolares, entre outros temas. Para Gadotti (2005) e Gohn (2010) apud Stadler (2019) “[...] o YouTube é um espaço de educação não formal, uma vez que propicia o aprendizado fora das instituições regulamentadas e certificadas por leis, como escolas e universidades". [...] "Os meios de comunicação de massa, as diversas tecnologias e as redes sociais também estão educando" (Stadler, 2019, p. 124).

Seguindo esse conceito, no meio dos vários canais e conteúdos que a plataforma apresenta, ressaltamos como forma de educação não formal objetivando a educação ambiental para o público da educação infantil, o Canal "João Ambiente".

Baseado em três pilares: educação, sustentabilidade ambiental e social e geração de renda e visando difundir a consciência ecológica em busca do equilíbrio do planeta, além de educar as pessoas sobre a importância da sustentabilidade e do respeito e inclusão social, produziremos o projeto ambiental multi-plataforma. "JOÃO AMBIENTE - AGORA É A HORA DE UM MUNDO MELHOR". (JOÃO AMBIENTE, 2018)

O canal conta com vídeos que abordam temáticas ecológicas de maneira lúdica e infantil, misturando desenho animado com imagens e fatos do mundo real fazendo um link entre os conteúdos, as problemáticas ambientais e ações de sustentabilidade. O personagem principal é o João, representado pelo pássaro conhecido como joão-de-barro, que utiliza de uma linguagem adequada ao público infantil, trazendo conceitos, saberes e ações referentes aos cuidados e a preservação da natureza.

É interessante frisar que a todo momento, João (2018) interage com os demais personagens levantando questões e apresentando exemplos que mostram claramente a mensagem que o enredo quer passar. Misturando o encanto que o desenho animado traz, podendo viajar no mundo real. Essa metodologia estimula a criança a ter um pensamento reflexivo de acordo com a realidade em que estamos inseridos.

Por fim, o canal apresenta-se como um recurso não formal alcançando objetivos educativos referentes às questões ambientais e sustentáveis, não impedindo que também 
seja usado no espaço formal. Traz também a temática muito bem abordada e condizente com uma aprendizagem significativa para crianças, podendo ser acessada em casa ou em demais espaços onde a educação pode acontecer de várias formas.

\section{DELIVERY DE JOANINHA}

Finalizando a pesquisa, foram analisados um recurso e uma ideia inovadora criada pelo casal e entomologistas, Guilherme Trivellato e Katherine Giron Perez. Eles desenvolveram o kit "Asas \& Cores" que é nada mais que um comércio on-line de joaninhas que pode, após os pedidos, serem enviadas por correio com material didático para ensinar as crianças sobre o ciclo de vida desses insetos.

Eles acreditam que o kit poderá aproximar as pessoas da natureza, mesmo que morem em apartamentos. Sem contar que além de serem excelentes hóspedes no jardim ou na horta de casa, as joaninhas são insetos muito eficientes em combater pragas e diminuir o uso de inseticidas.

No kit, eles desenvolveram um habitáculo com larvas das joaninhas e ovos de mariposa esterilizados, que servem de alimento, com quantidade suficiente para o tempo de desenvolvimento de duas semanas até a fase adulta. "Estudamos o espaço para garantir um formato que não coloque a comida em contato com a água e que tenha troca de ar. (ABDO, 2021).

Assim, depois de nascerem e soltas, as joaninhas poderão viver a sua vida. Segundo o casal, elas são insetos autônomos, possuem a capacidade de se alimentarem de pulgões, ácaros e outros insetos e, logo na vida adulta, irão colocar seus ovos para germinar outras joaninhas (ABDO, 2021).

Portanto, entende-se que essa metodologia é excelente para desenvolver a consciência e a educação ambiental em crianças da educação infantil, pois além de participarem de uma experiência totalmente educativa, poderão compreender a importância de um inseto na natureza e aprender ações sustentáveis, como por exemplo: a diminuição do uso de inseticidas. 


\section{CONSIDERAÇÕES FINAIS}

Perante a análise dos materiais vistos na atual pesquisa bibliográfica, foi nítido perceber que a educação acontece de várias formas fora dos espaços escolares e, dessa maneira, há uma contribuição significativa na formação do indivíduo como um todo.

A criança incluída na educação infantil, está em fase de desenvolvimento, curiosidade e também de conhecimento do mundo que a cerca. Assim, é de fundamental importância estimular os vários conhecimentos e recursos didáticos para contribuir na consolidação dos saberes necessários ao seu crescimento.

A Educação Ambiental é fundamental no cotidiano do ser humano e, na fase infantil, se for ensinada/mediada de forma lúdica, dinâmica e atrativa, poderá ressignificar a visão de mundo que cresce com a criança. Através da tecnologia atual, esse ensino pode ocorrer de maneira diversificada, levando os conceitos de preservação do ambiente e ações sustentáveis em locais em que a educação não formal acontece, como em: ONG's, Pastorais, Projetos Sociais, Igrejas, aplicativos de celular, páginas da internet, televisão, músicas, brinquedos, jogos, brincadeiras, entre outros.

Pelo exposto, entende-se que a educação ambiental aplicada no ensino não formal da educação infantil, pode auxiliar na formação de indivíduos críticos e integrais, capazes de buscar e agir em prol de um mundo melhor através de ações sustentáveis e preservação do meio ambiente.

\section{REFERÊNCIAS}

ABDO, Humberto. Casal especialista em insetos lança delivery de joaninhas. Veja São Paulo: Publicado em 9 abr 2021, 06h00. Disponível em: <https://vejasp.abril.com. br/consumo/delivery-joaninhas/> . Acesso em 15 de janeiro de 2022.

BRASIL. Base Nacional Comum Curricular. MEC, 2017. Disponível em: http://basenacionalcomum.mec.gov.br/abase/ . Acesso em: 13 jan. 2022.

BRASIL. Lei n. 9795, de 27 de abril de 1999. Dispõe sobre a educação ambiental, institui a Política Nacional de Educação Ambiental e dá outras providências. Presidência da República Federativa do Brasil, Brasília, DF, 1999. Disponível em: http://www.planalto. gov.br/ccivil_03/leis/19795.htm. Acesso em: 13 jan. 2022. 
Lei n. 9985, de 28 de julho de 2000. Regulamenta o art. 225, § 1o, incisos I, II, III e VII da Constituição Federal, institui o Sistema Nacional de Unidades de Conservação da Natureza e dá outras providências. Presidência da República Federativa do Brasil, Brasília, DF, 2000. Disponível em: http://www.planalto.gov.br/ccivil_03/leis/ 19985.htm\#: :text=L9985\&text=LEI\%20No\%209.985\%2C\%20DE\%2018\%20DE\%20 JULHO $\% 20$ DE $\% 202000 . \&$ text=Regulamenta $\% 20 o \% 20$ art., Natureza $\% 20 \mathrm{e} \% 20 \mathrm{~d} \%$ C3\%A1\%20outras\%20provid\%C3\%AAncias. Acesso em: 13 jan. 2022.

BRASIL. Ministério da Educação. Conselho Nacional de Educação. Câmara de Educação Básica. Parecer CNE/CEB n. 20, de 11 de novembro de 2009. Revisão das Diretrizes Curriculares Nacionais para a Educação Infantil. Diário Oficial da República Federativa do Brasil, Brasília, DF, Seção 1, p. 14, 9 dez. 2009.

CANALTECH. YouTube: novos tempos, novos ídolos. Youtube, 18 jun. 2012. Disponível em: <https://canaltech.com.br/empresa/youtube/>. Acesso em: 13 jan. 2022.

CORSARO, William A. Sociologia da Infância. 2 ed.Tradução de Lia Gabriele Regius Reis. São Paulo: Artmed, 2011.

FREIRE, Paulo. Pedagogia da Autonomia: saberes necessários à prática educativa. Rio de Janeiro: Paz e Terra, 1996.

GOHN, M. Educação não-formal e cultura política. São Paulo: Cortez, 2007

HOSHINO, Camila. Educação ambiental: preparando crianças para desafios do futuro. Lunetas, 2020. Disponível em: <https://lunetas.com.br/educacao-ambiental/ > Acesso em: 13 jan. 2022.

JOÃO AMBIENTE. João Ambiente. Youtube, 22 mai. 2018. Disponível em: $<$ https:// www.youtube.com/watch?v=JRBxX3VulgE $>$. Acesso em 13 de janeiro de 2022.

JACOBI, P. Educação ambiental, Cidadania e sustentabilidade. In: Cadernos de Pesquisa, n. 118, mar. 2003, p. 189-205. Disponível em: . Acesso em 15 jan. 2013.

LIBÂNEO, José Carlos. Pedagogia e Pedagogos: para que?. São Paulo: Cortez, 2002.

MARÍLIA. Afinal, você sabe o que é Educação Não Formal? Instituto Now, [2020]. Disponível em: https://www.institutonow.org/voce-sabe-mesmo-o-que-e-educacao-nao-formal/. Acesso em: 13 jan. 2022 
MULULO, Jorgete Comel Palmieri, NORONHA, Evelyn Lauria. As Interações das Crianças: o aprender ciência em espaço não formal. In: FÓRUM INTERNACIONAL DE PEDAGOGIA, Campina Grande, Vol. 1, ed. 4. Parintins-AM: Realize, 2015. Disponível em: <https://www.editorarealize.com.br/editora/anais/fiped/2015/TRABALHO_EV050_MD1_SA12_ID421_23102015232422.pdf > Acesso em: 13 jan. 2022.

RAMOS, Marcela Fernanda. Educação não formal: pedagogia social transformadora e motivadora. Canal Colaborativo Meu Artigo, [20--]. Disponível em: https://meuartigo.brasilescola.uol.com.br/pedagogia/\%20educacao-nao-formal.htm. Acesso em: 13 jan. 2022.

SARMENTO, Manuel Jacinto. Gerações e alteridade: Interrogações a partir da Sociologia da Infância (p.361-378). In: Educação e Sociedade, Campinas, v.26, n.91, maio/ ago. 2005.

SITE. João Ambiente: agora é a hora de um mundo melhor. Disponível em $<$ http:// www.joaoambiente.com.br/downloads/joaoambiente2019.pdf $>$. Acesso em 17 de janeiro de 2022.

STADLER, Pâmella de Carvalho. Youtube como ferramenta de educação não formal: boas práticas para a produção de vídeos educativos com base nos aspectos da linguagem de youtubers. Curitiba, 2019. $183 \mathrm{f}$. Disponível em: $<$ https://repositorio.uninter.com/bitstream/handle/1/410/Disserta \%c3\%a7\%c3\%a3o-P\%c3\%a2mella\%20de\%20 Carvalho\%20Stadler\%202019.pdf?sequence=1\&isAllowed=y $>$ Acesso em: 13 de janeiro de 2022. 


\section{SOBRE OS ORGANIZADORES}

\section{Rodrigo Duarte Faccin}

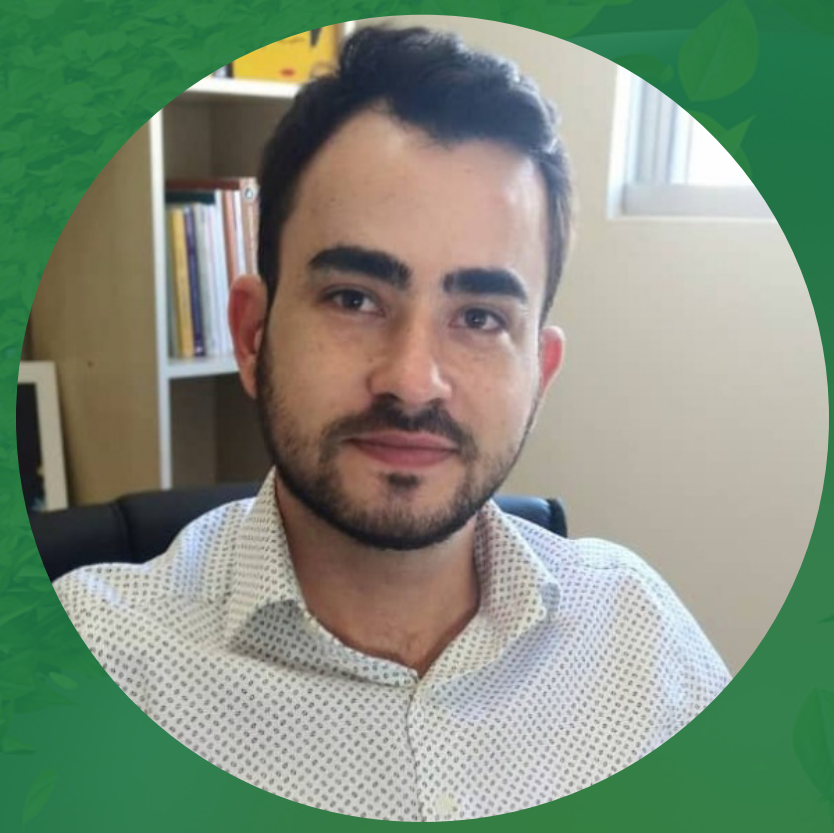

Bacharel em Administração pela Universidade Regional Integrada do Alto Uruguai e das Missões, Campus Santiago, Mestre e Doutor em Extensão Rural e Desenvolvimento pela Universidade Federal de Santa Maria. Atualmente é aluno na mesma instituição do Programa Especial de Graduação de Formação de Professores Para a Educação Profissional (PEG). Possui experiência em docência universitária e em consultoria empresarial. Possui interesse pelos seguintes temas de pesquisa: Administração Rural, Relações Sociais de Trabalho, Desenvolvimento Local e Regional, Gestão de Pessoas e Gestão da Inovação. 


\section{Gabriella Eldereti Machado}

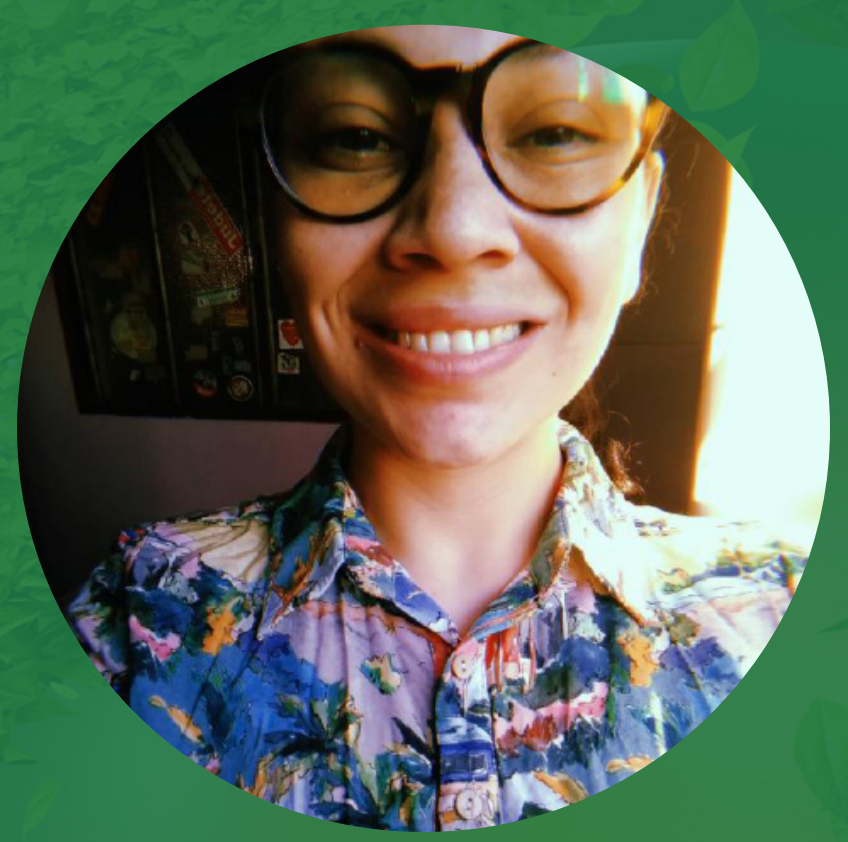

É Licenciada em Química pelo Instituto Federal de Educação, Ciência e Tecnologia Farroupilha - IF Far - Campus Alegrete (2015) e Pedagoga pelo Centro Universitário Facvest - Unifacvest (2020). Especialista Educação Ambiental pela Universidade Federal de Santa Maria (2016), Mestre em Educação pela Universidade Federal de Santa Maria (2018). Atualmente é Discente do Programa de Pós - Graduação em Educação - Doutorado em Educação na Universidade Federal de Santa Maria. 


\section{Erimar Pereira da Rocha}

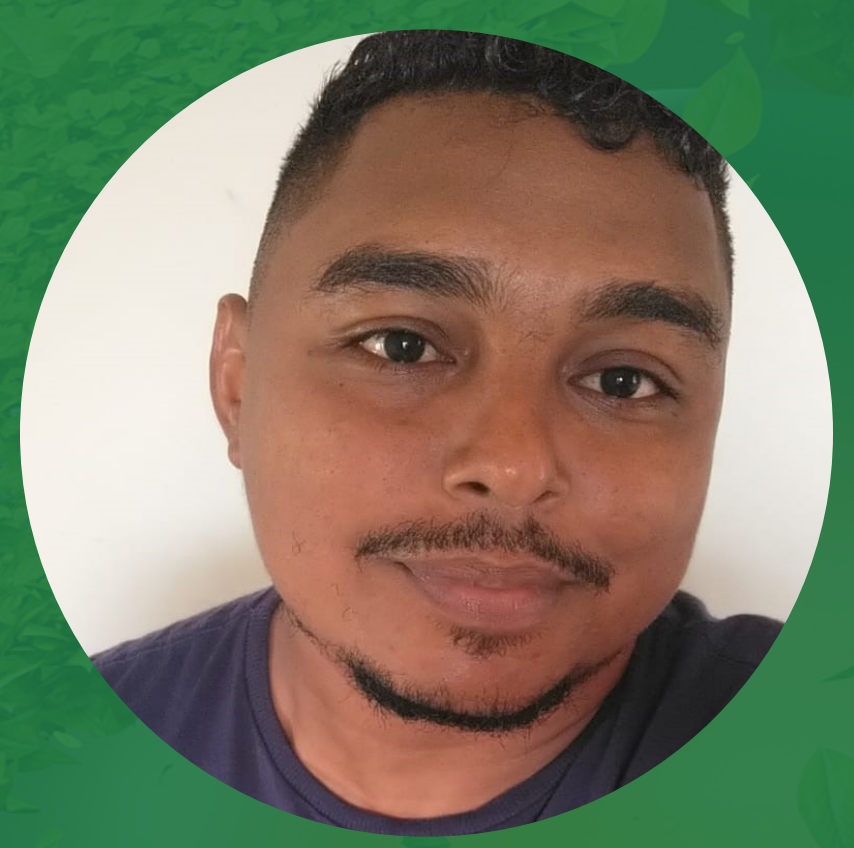

É graduado em Licenciatura em Pedagogia pelo Centro Universitário Maurício de Nassau (UNINASSAU/FAP), Letras Português - Inglês pelo Centro Universitário de Maringá (UNICESUMAR), Professor atuante na Educação Básica e Superior, Especialista em Gestão Educacional em Rede pela Universidade Federal do Piauí (UFPI) e Psicopedagogia Clínica e Institucional pela Faculdade Única de Ipatinga (FUNIP). Mestrando em Tecnologias Emergentes em Educação pela MUST University, Florida - EUA.

E-mail: erimardarocha@gmail.com

Lattes:http://lattes.cnpq.br/6697118935645189 


\section{SOBRE AS AUTORAS E OS AUTORES}

\section{Alex de Lima e Silva}

Doutorando Engenharia Elétrica / Eletrônica de Potência na COPPE - Universidade Federal do Rio de Janeiro - UFRJ. Doutorando no curso de Ciências da Educação na Universidade Columbia del Paraguay - PY. Mestre em Desenvolvimento de Tecnologia para - Sistemas Energéticos Convencionais e Alternativos pelo Instituto LACTEC. Pós-Graduado em Gestão de Projetos pela Pontifícia Universidade Católica - PUC. Pós-Graduado em Engenharia de Manutenção pela Pontifícia Universidade Católica - PUC. Graduado em Engenharia Elétrica pelo CEFET - Centro Federal de Educação Tecnológica - Celso Suckow da Fonseca. Pesquisador em propriedade Industrial junto ao Instituto Nacional de Propriedade Industrial - INPI. Consultor em sistemas energéticos do Sistema Interligado Nacional. Docente na Universidade Santa Úrsula - RJ para os cursos de Engenharia Elétrica. Docente na Universidade Unigama - RJ no curso de Pós Graduação em sistemas de energia.

E-mail: prof.alexdelima@gmail.com

Orcid: https://orcid.org/0000-0003-1664-6239

\section{Cintia Regina Pavão Castelo Branco}

Graduação em Hotelaria pela Universidade Federal do Maranhão (1996) e Bacharel em Nutrição pela Universidade CEUMA (2009). Licenciada em Letras Português e Literatura pela Faculdade Uniasselvi de Santa Catarina em 2018. Graduanda em Pedagogia pela Faculdade de Santa Catarina - Uniasselvi. Especialização em Docência do Ensino Superior pela Faculdade Atenas Maranhense - atual Faculdade Pitágoras em 2004. Mestranda em Educação com linha de pesquisa em Formação de Professores pela Universidad Europea del Atlántico (UNEATLÁNTICO) - ESPANHA e Professora Formadora e Tutora pela Universidade do Estado do Maranhão - UEMA.

\section{Danilo Fernandes Lobato}

Possui Licenciatura Plena em Educação do Campo - Habilitação Ciências da Natureza pela Universidade Federal de Goiás/Regional Catalão. Bacharelando em Direito pela Universidade Estadual de Goiás (UEG) - Campus Pires do Rio

E-mail: danilo.fernandes65@gmail.com 


\section{Evandro José Branches Lopes Filho}

Doutorando em Ciências da Educação (Universidad Columbia del Paraguay - PY); Mestre em Educação Profissional e Tecnológica (IFAM). Especialista em MBA Executivo em Gestão Pública (UCAM); Graduado em Administração (ULBRA); Graduado em Enfermagem (UEPA). Licenciado em Pedagogia e Formação Pedagógica Docente em Letras (UNIFAEL). Graduando em Direito (UFOPA). Atua no Cargo de Técnico Administrativo, Função Assistente em Administração na Universidade Federal do Oeste do Pará - UFOPA desde 2014. Desenvolve pesquisas em Práticas Educativas em Educação - Profissional e Tecnológica.

E-mail: ejvandinho20@gmail.com

Orcid: https://orcid.org/0000-0003-2233-9980

\section{Leidiane Aparecida dos Santos}

Graduada em Pedagogia - Universidades Estadual de Goiás - (UEG), Educação Física - Centro Universitário Faveni - (UNIFAVENI); Especialista em Metodologia do Ensino e da Pesquisa com Habilitação em Psicopedagogia - (FMB), Gestão Escolar (UNIASSELVI) e Docência para a Educação Profissional e Tecnológica - (IFES).

\section{Maria Betânia de Oliveira Marques}

Gestão em Recursos Humanos pela Universidade Paulista - (UNIP), licenciada em Pedagogia pela Universidade Federal de Alagoas - (UFAL), pós-graduada em Educação em Direitos Humanos pela Universidade Federal de Alagoas - (UFAL) e mestranda em Educação: Especialização em Formação de Professores - Universidad Europea del Atlántico - Espanha (UNEA). email: betania102@hotmail.com, Lattes: http://lattes. cnpq.br/4291121442773470

\section{Olga Matias Teles Honorato}

Possui Licenciatura Plena em Pedagogia pela Universidade Estadual de Goiás (UEG) e Licenciatura em Letras: Português/Espanhol pela Faculdade Geremário Dantas - RJ. Mestranda em Educação pelo Programa de Pós-Graduação em Educação da Faculdade de Educação (FaE) da Universidade Federal de Catalão (UFCat).

E-mail: olgamatiasteles2019@gmail.com 


\section{Patricia Laurindo da Cunha Passos}

Doutoranda em Ciências da Educação (Universidad Columbia del Paraguay - PY); Mestra em Ciências da Educação (Universidad Columbia del Paraguay - PY); Pós-Graduada em Gestão e Psicopedagogia pela Faculdade de Tecnologia de Cachoeiro de Itapemirim (FACI); Graduada em Pedagogia pela Universidade Paulista (UNIP); Cachoeiro de Itapemirim- ES. Atualmente é docente no Instituto Federal do Espírito Santo - IFES. E-mail: patricialaurindolc@gmail.com

Orcid: http://orcid.org/0000-0002-6199-1237

\section{Paulo Roberto Valdo Thomaz}

Doutorando em Ciências da Educação (Universidad Columbia del Paraguay - PY); Mestre em Ciências das Religiões (Faculdade Unida de Vitória); Pós-Graduado em Educação Física Escolar (FATESF); Pós-Graduado em Gestão Escolar Integradora (FAEV); Pós-Graduado em Esportes e Atividades Físicas para Pessoas com Deficiência (UFJF); Pós-Graduado em PROEJA (IFES); Pós-Graduando em Docência no Ensino de Dança (FASUL-MG); Licenciado e Bacharel em Educação Física (São Camilo - ES); Licenciado em Pedagogia (UNIFAEL). Atua no Ensino Fundamental como professor de Educação Física na Prefeitura Municipal de Marataízes/ES e como Pedagogo na Prefeitura Municipal de Viana/ES.

E-mail: paulorobertovaldo@gmail.com

Orcid: https://orcid.org/0000-0003-3717-8526

\section{Patrícia Vasconcelos Costa}

Doutoranda em Ciências da Educação (Universidad Columbia del Paraguay - PY); Mestra em Ciências da Educação (UNIBE). Possui Graduação em Pedagogia pela Universidade Federal do Amazonas (2012). Especialista em Psicopedagogia. Servidora Pública Estadual - Pedagoga. Com Experiência em Coordenação Pedagógica e Supervisão em Escolas e Coordenadoria de Educação. Com experiência na Docência no Ensino Superior na UFAM com ênfase em Educação Inclusiva, Psicomotricidade, Coordenação Pedagógica, Fundamentos da Educação Infantil, Arte Educação, etc. Também com experiência na Educação Básica, Professora e em Atendimento Educacional Especializado. E-mail: patricia.costa@seduc.net

Orcid: https://orcid.org/0000-0003-3768-2239

\section{Renata José de Melo}

Possui licenciatura em Educação do Campo - Habilitação em Ciências da Natureza pela Universidade Federal de Goiás/Regional Catalão. Mestranda em Educação pelo Programa de Pós-Graduação em Educação da Faculdade de Educação (FaE) da Universidade Federal de Catalão (UFCat).

E-mail: renatajosedemelo@gmail.com

Orcid: https://orcid.org/0000-0002-9613-039X 


\section{Rose Cléia Maria Barros Mendes}

Doutoranda em Ciências da Educação (Universidad Columbia del Paraguay - PY); Mestra em Maestría Internacional en Coaching y en Inteligencia Emocional Infantil y Juvenil - Esneca Business School (2021) e Mestrado em Maestría Internacional en Pedagogía y Psicopedagogía Clínica - Esneca Business School (2021); Especialista em Psicopedagogia Clínica pela Faculdade Integrada Brasil Amazônia (FIBRA); Licenciatura Plena em Pedagogia pela Universidade Paulista (UNIP). Atualmente é professora na Secretaria Estadual de Educação (PA). Tem experiência na área de Educação, com ênfase em Educação em Ensino Fundamental I e Psicopedagogia Clínica.

E-mail: cleinhabm@gmail.com

Orcid: https://orcid.org/0000-0002-6929-7047

\section{Simara Maria Tavares Nunes Simões}

Licenciada e Bacharel (1995) em Química, Mestre (1999) e Doutora em Ciências (2003)

- Área de Concentração Química - pela Faculdade de Filosofia Ciências e Letras de Ribeirão Preto da Universidade de São Paulo. Atualmente é Professora Associada da Faculdade de Educação da Universidade Federal de Catalão, na área de Ensino de Química.E-mail: simaramn@gmail.com

\section{Ueudison Alves Guimarães}

Graduado em Pedagogia - Universidade Luterana do Brasil - (ULBRA), Química - Faculdade Cidade João Pinheiro - (FCJP), Matemática - Centro Universitário Claretiano - (CLARETIANO), Geografia - Faculdade Mozarteum de São Paulo - (FAMOSP) e Física - Centro Universitário Faveni - (UNIFAVENI); Professor de Pedagogia, Química, Matemática, Geografia e Física, atuante na Educação Básica e Ensino Superior; Especialista em Gênero e Diversidade na Escola - (UFMT), Educação das Relações Étnico-Raciais no Contexto da Educação de Jovens e Adultos - (UFMT), Metodologia do Ensino em Química - (FIJ-RJ), Libras e Educação Inclusiva - (IFMT) e Docência para a Educação Profissional e Tecnológica - (IFES); Mestrando em Educação: Especialização em Formação de Professores - Universidad Europea del Atlántico - Espanha (UNEA) e Mestrando em Tecnologias Emergentes em Educação (Must University).

E-mail: ueudisonverde@hotmail.com.

Lattes: http://lattes.cnpq.br/7975329809972139.

Orcid: 0000-0003-0592-2496 
8

\& 8

6.

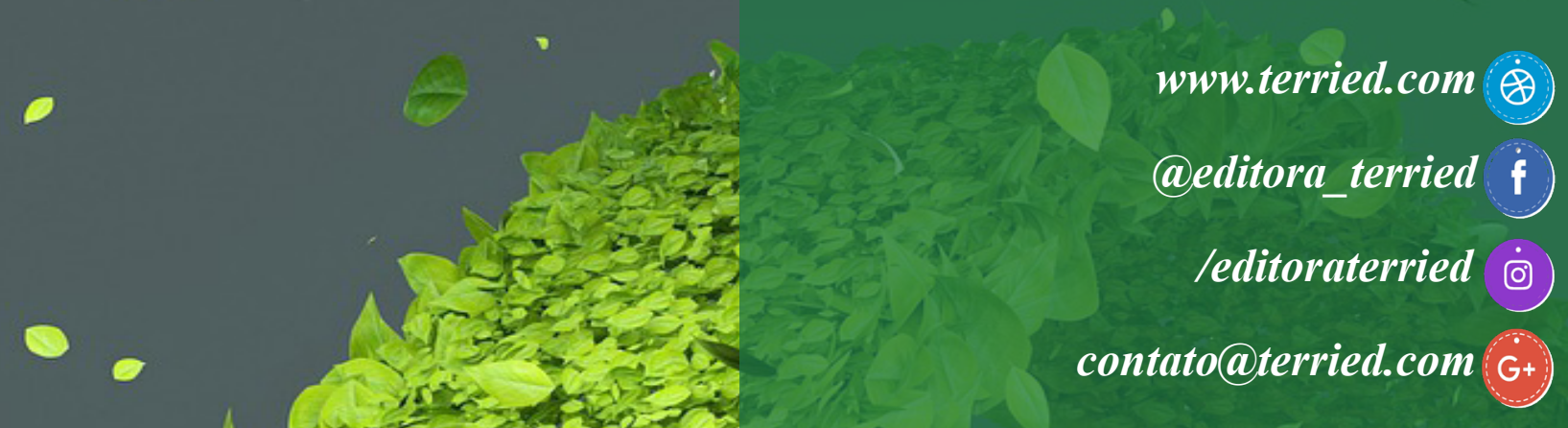

a.

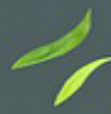

2

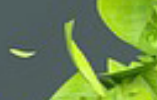

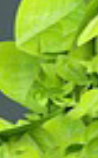

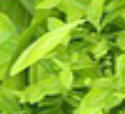
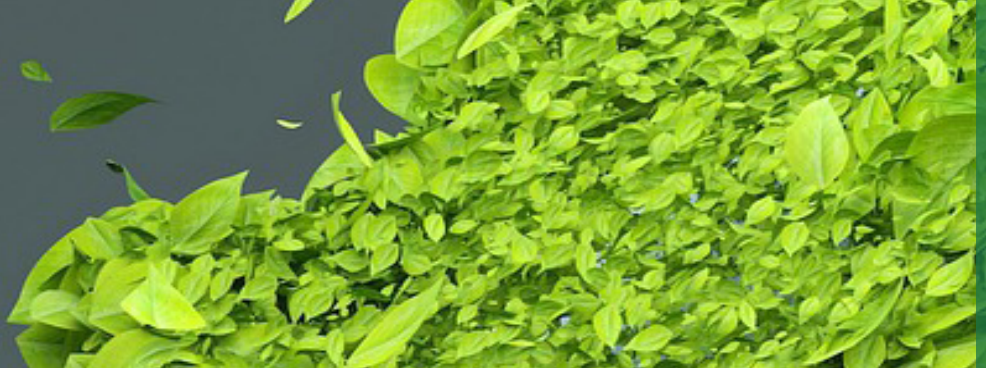
of 200

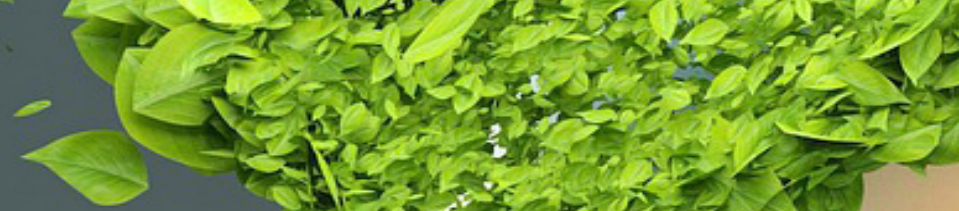

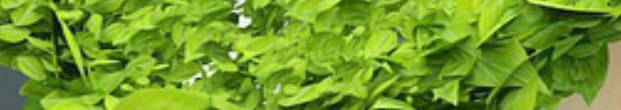
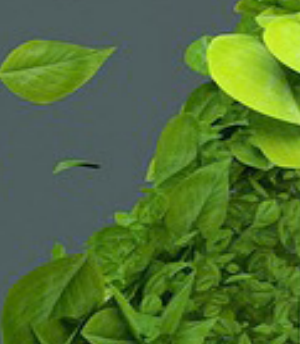

3) 1 - 10

\section{$\frac{2}{3}$

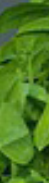

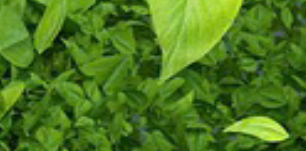

ares

and 8

finges?
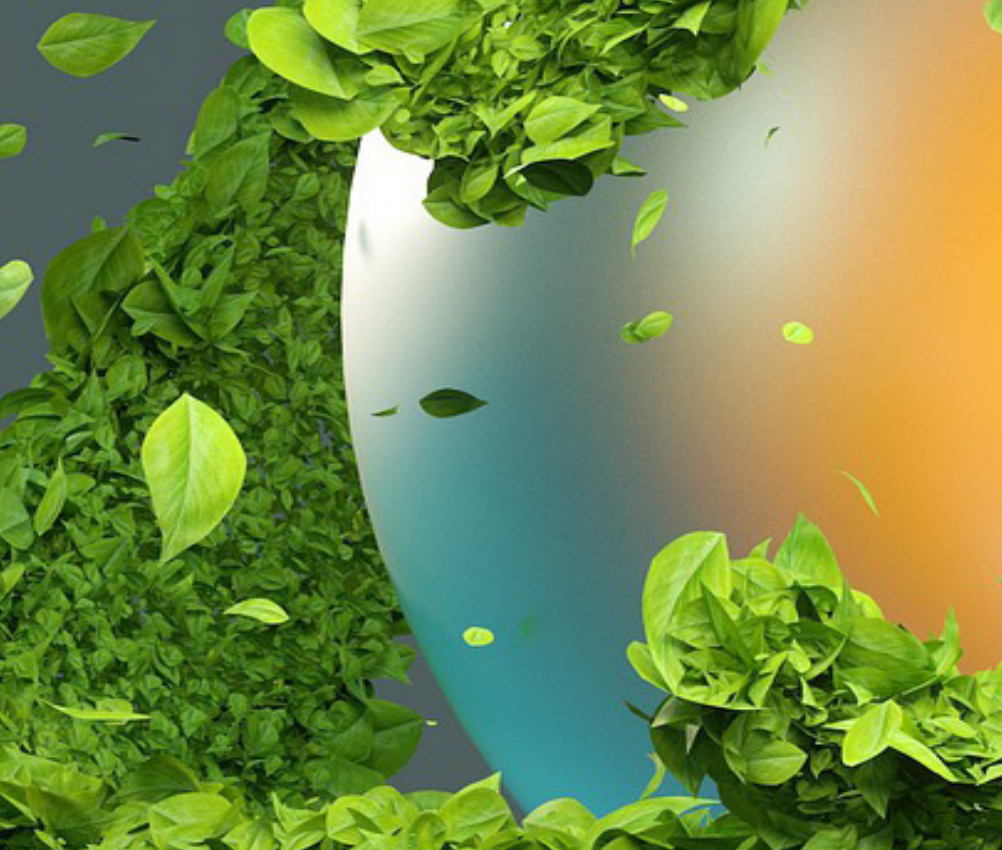

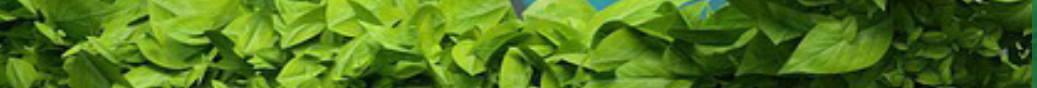

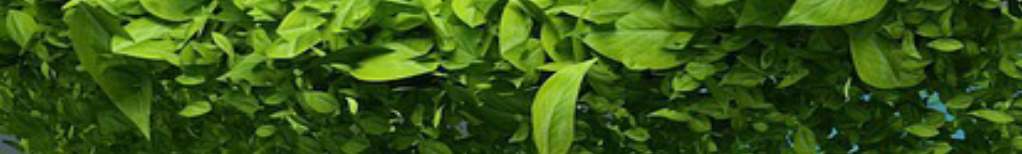

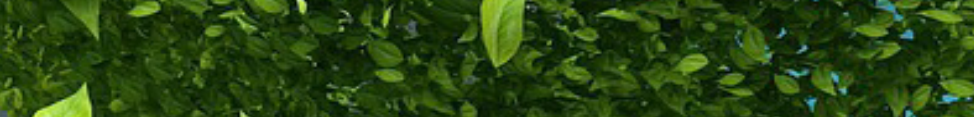
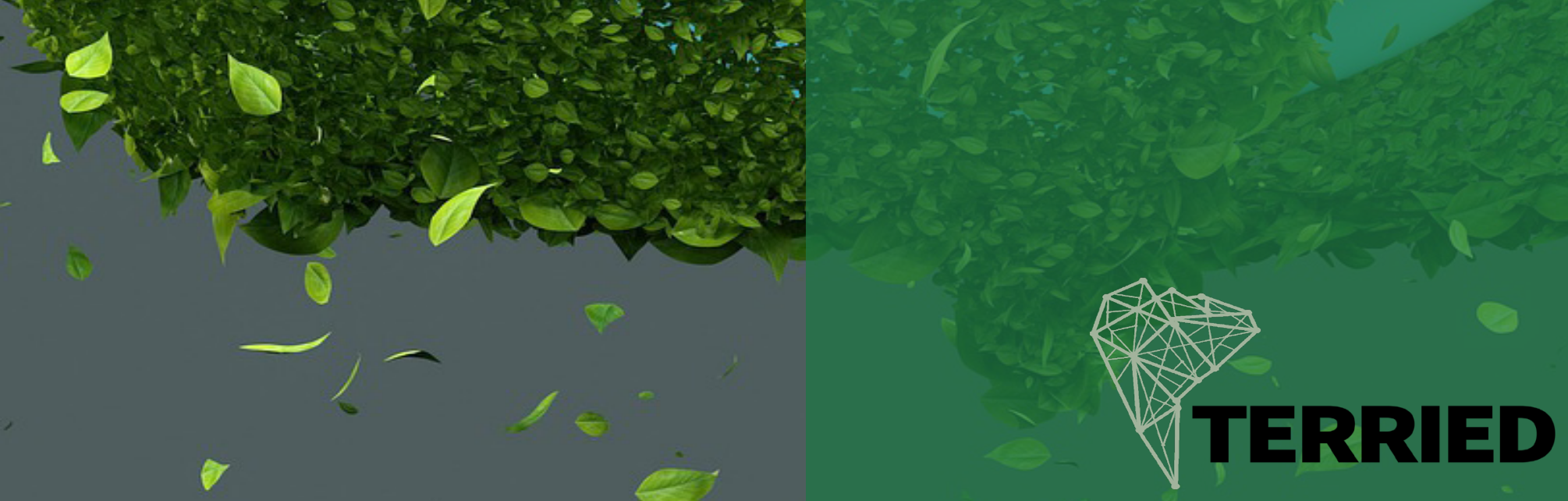